\title{
SK 41
}

. F5

Copy 1

Percy Coleman Field 



\section{Four Dude Hunters}

Percy Coleman Field 


\section{$S K A^{\prime}$
$F 5$}

\section{跑edicated}

TO MY FRIENDS WHO WOULD RATHER GO HUNTING AND FISHING-

$$
\text { JUL }-91918
$$

(C) CI.A501082

COPYRIGHT, 1918, Percy Coleman Field. 


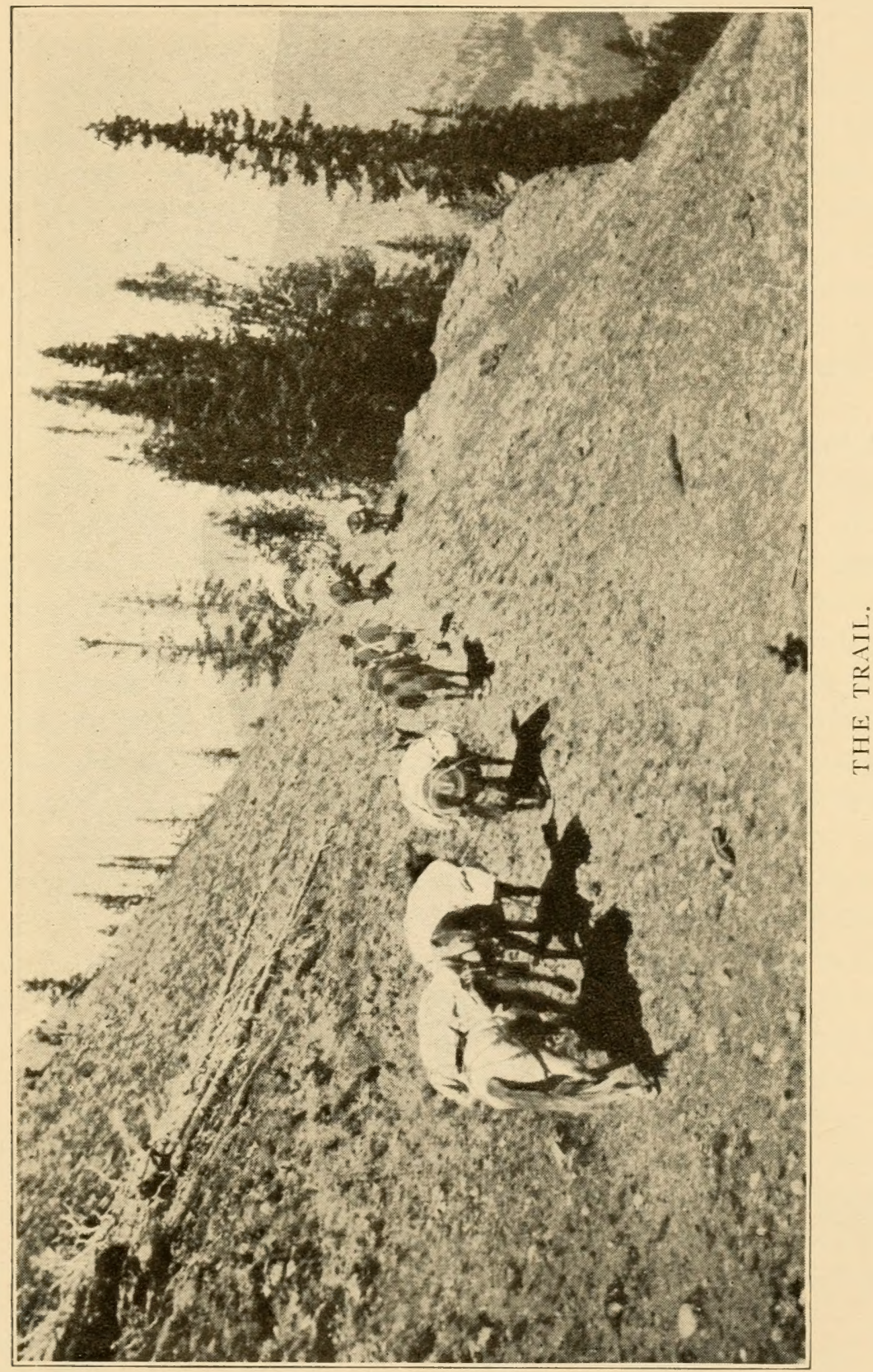





\section{FOUR DUDE HUNTERS}

\section{CHAPTER I.}

Wednesday, August the twenty-second, nineteen hundred and seventeen, was as hot in Kansas City as it might be expected to be anywhere, excepting possibly that place often described on Sunday by a class of men, who generally wear long faces and equally long black coats, as the just reward for the evil-doer. In fact, considerably too warm for a strong, healthy person, who could enjoy a game of golf, to work in the city; yet, enough sunshine, as the golf wags put it, "to make the sap flow freely."

Shortly after lunch on this particular day, there was a large motor car speeding along the winding road in Jackson county, which leads from Kansas City, Missouri, to Hillcrest Country Club. The car was operated by a pleasant looking chauffeur. In its well upholstered tonneau two men very close to thirty-five years of age were seated. They were dressed in fresh suits of palm beach clothes; and, in addition to their fresh linens, one of them, a wiry specimen of manhood of good height and weight, wore a cigar with a gold band about it; while the other, a dark complexioned plump fellow, tall enough to be considered lanky, had it not been for his plumpness-which might be called corpulency-wore a Missouri meerschaum, with an amber stem and a brass band about its muzzle. These two young men were feeling very good toward one another, and the world: they were healthy and happy. As the car rolled on toward their ultimate goal they laughed and talked with each other very much as young men, carefree and with nothing immediately before them excepting a game of golf, usually would ; yet, for some reason or other, the dark complexioned young man took a long puff at his meerschaum, paused, turned to look out into a wooded country to his left, and there for a few moments gazed steadfastly.

"I hope you are not bored with your company, Percy?" urged his friend, Mr. William G. Dilts, Jr., who, by his good fellowship, was always spoken of as Bill. 
"Bored, my dear boy? Bored! Oh, no. I am charmed, yet," said Percy C. Field, a lawyer of Kansas City. "Bill! Did you hear that?"

"What?" asked Bill, looking mightily like we had a puncture.

"Oh, no," said Percy, smiling, "it is not a puncture or anything, it is the call of the wild. My dear friend, excuse me and my fancy-when I look out into the woods, I can't help, at this time of the year, to hear something calling: it is the call of the wild. Think of it! The twenty-second day of August-the courts are all practically closed. I have had to remain to wind up some personal business, but next week, and thank goodness for that, I leave for Northern Michigan. A golf course is up there. The air is delightfully cool and refreshing. It is a wonderful country. Come and go with me."

"I thought you had a call for the wild?" questioned Bill smiling, as he took a puff at his cigar.

"I did, and that is why I do not look forward to my Michigan trip this year. Business has demanded that I be here in Kansas City a few days too long this year. I missed a trip in the wilds of Minnesota-canoeing, swimming, fishing; fishing and the catching of big fish; camping and roughing it, so I thought I would compromise with a few weeks of golf. Come and go with me, my dear friend, and we shall have some exciting games."

"Percy!" spoke Bill earnestly and enthusiastically, "if you love nature and can enjoy a real wilderness, come with me. I leave Friday, the twenty-fourth, for the Rocky Mountains. In the course of a few days' travel and a week's pack on horses and mules over the mountains, we shall come into the greatest of all wild places. There, perhaps, a hundred miles from civilization and the railroads, we shall hunt and fish. We shall hunt bull elk; and perhaps see a mountain lion, a grizzly bear; deer of all sorts; and hunt mountain sheep; and a great many other kinds of big game. We shall camp in the snowy peaks. Say you will go. I 
shall then wire my friend at Cody, Wyoming - the old home of Buffalo Bill - to engage a guide for you. Everything will be in readiness, and shall await your pleasure. Percy, it is just the trip for you. You will not have hay fever there. You may never have another such opportunity, and-it is just the thing for your health. Say the word now, and I'll send the wire by 'phone from the club house."

"All of that sounds good to me, Bill, but let me think of it a minute or so. Let me see. How far do we go? How long does it take?" Percy meditated. "Are you going to make this trip alone?"

"Of course not! You are going. Then there is my friend Floyd, and a friend of Floyd's, Joe; Joe McCandless. They are both fine fellows. You will enjoy every minute you spend with them. Floyd-Floyd Hipple is his name, and he is in the grain business at Hutchinson, Kansas; and Joe, well, Joe is an up-to-date farmer. The two of them are the best of company. We have been planning this trip for a long time. Well, this is your luck, Percy. Here we have figured out everything, written all sorts of letters inquiring about this and that; and now everything is awaiting your pleasure. Say the word, my dear friend, and it is all yours to see and to enjoy."

As the car pulled up at Hillcrest Country Club one of the young men was deep in thought. He had a very important golf game on. He was next to the runner-up in a summer championship. He dearly enjoyed the game, and especially a game with his friend Bill, but he had again heard the call of the wild. It was sounding loudly. As he dressed for golf he dreamed of the mountains and of the big game.

"Come on, Percy, and let us play this game, and then I'll send the wire. Or shall I send it now?" asked Bill, in full golf attire, as he approached the locker of Percy.

"What? Can't find a shirt? Here! Permit me to lend you this one of mine. I've just brought out a number of clean ones." 
"Thank you, Bill. Oh, yes, I can wear it by leaving the top button apart. It is a little snug, yet I feel mighty lucky to have the extra shirt. I thought to bring some out this morning, before breakfast, but it slipped my mind. All right, I am ready. Come on."

The two went out to number one tee and drove. Percy played four straight pars, and one hole below par. At the end of the first nine, Percy had Bill four down and nine to play.

"Percy," said Bill, jokingly, after Percy had driven straight down the course nearly three hundred yards, "if I win this game will you go with me to the mountains?"

"Will I go with you? May I go if I lose?" said Percy, realizing that there could be as many a slip in golf as "between cup and lip."

"Why, of course. Say the word now! I will beat you today and perhaps you will have more luck hunting," cried Bill joyfully.

"All right, I'll go," Percy replied slowly.

Bill smiled and walked over to shake hands with his companion. He appeared to be thinking more of the decision of his friend than the game; nevertheless, he teed his ball, and struck at it with a careless disregard for its destination. The ball was hit squarely, the stroke beautifully executed with a precise follow through. The ball didn't stop going until it was even with that of his opponent. Bill continued to play golf as he never played before, while Percy heard the call of the wild to the tune of two down and one to play.

"And such is life: the best part about it," said Percy, as they walked to the club house after he had congratulated Bill, "for when you are down, and a long ways down, there's always a chance to get up again."

"Yes, there is always a chance in everything: when you are about to win you often lose; and when you are about to lose, you often win." 
"It was a fine game, Bill," urged Percy as they played the much relished nineteenth hole, enjoying a cold bottle of root beer.

"Yes, it was. The next time I want to beat a big fellow in hot weather, I am going to lend him one of my shirts. $\mathrm{Ha}$, ha; I didn't do it on purpose, Percy, but after we reached the tenth hole you got to sweating, and the shirt got to sticking to you, and you almost did a midway dance each time before hitting the ball-the shirt stuck to you, and you didn't have a free swing through-why, that's how I. came to beat you."

"Oh," laughed Percy, "that's the spirit. Beat a fellow and then furnish him with an alibi. But I now say, "be that as it may,' tell me more about the big game we are going to play in the Rocky Mountains-I believe you said it was somewhere in Wyoming?"

After a refreshing drink, a cool shower and fresh linens the two young men were again seated comfortably in the car, which was speeding for Kansas City. Bill was talking most interestingly. Percy at times held his breath and occasionally his eyes would grow large and round.

"And that shall be our trip?" added Percy, with the keenest anticipation, "and we start Friday?"

"Friday at six p. m. I shall order a duplication of everything I have for you. I took the sizes of your shoes and clothes from your golf clothes and shoes. The Arms Company will fit you out the same as I have been fitted out by them, with a rifle and such ammunition as you will need, and everything. I want you thoroughly prepared, for you might come face to face with a great big grizzly bear, or a mountain lion, or God knows what, and I want my friend to have a fair chance to come back."

"That's very kind of you, Bill. All right; I'll take that chance," added Percy, jocularly.

"Remember," insisted Bill, "it is Friday, at six p. m. Wind up your business for six weeks-and you might make out your will." 
"All in a day and a half ?" interrupted Percy.

"And explain the matter to your wife. Friday, on the twenty-fourth day of August, you will leave with me. You'll be gone for six weeks. You will go into a far and distant country. There you cannot even write to your wife or friends, or receive letters from them, but there, my dear boy, you can answer the call of the wilds to your heart's content; or the call of a coyote or whatever might happen to be calling you out there, from a grizzly bear down to a chipmunk."

"All right, Bill," added Percy.

Yet such a thing was not so simple for Percy. I dare say that he would have approached the Bar of Justice, with the most guilty culprit to defend, rather than his dear wife, with the suggestions that he believed it would be best for his health to leave Kansas City entirely and go to a place a hundred miles or so from any form of civilization. Bill had accomplished this undertaking, and, as Bill had, Percy took courage.

\section{CHAPTER II.}

Friday, August the twenty-fourth, a few minutes before six o'clock, a number of young folk approached the westbound Burlington train. Two of the young women of the party had fitted themselves so snugly in the arms of their escorts that their arrival at the Pullman entrance caused the porter to smile from ear to ear, doubtless anticipating a double honeymoon. He hurriedly gathered up the hand baggage of the men and took it away to a stateroom. Yet a casual observance of the faces of the young women would have revealed a more somber shade of life.

"All abode!" shouted the porter, a yellow, freckle-faced individual, whose dream of a double honeymoon had almost vanished. 
Percy kissed dearie again, and said "Goodby."

He boarded the car and found that Bill had again put one over on him, by removing the screen from the window of the car, and was just in the act of being separated from his dearie by the motion of the train.

"Be careful, Bill!" urged Percy. "Remember what happened to the cow a mile down the track when once a newlywed kissed his bride in just such a way?"

So it was, goodby, dearies; goodby, Kansas City; goodby, friends of ours! We shall call upon you within six weeks, but until then, fare thee well.

As the train sped on its way we talked, and read, and talked and read, stretched and smoked, and talked and read some more; dined, and talked and read some more. The hour had grown late and the shades of night had fallen.

"Percy, try one of these cigars," urged Bill, as he extended a fine looking cigar.

"Thanks, Bill, thanks! I prefer my old companion here," smiled Percy, as he produced his old battle-worn meerschaum.

"Percy," said Bill, after thinking seriously about something and blowing a volume of smoke into the upper berth of the state room, "we are going into a wild country: did you make out your will?"

"No; never thought of it. Yet, why?"

"Oh, nothing particular, excepting a fellow like you is just fat enough to make a good meal for a grizzly bear-too fat to run in a high altitude; and, of course," smiled Bill, "I don't know whether you can shoot a gun or climb a tree."

"You don't!" laughed Percy, and then he took a puff at his pipe.

"Well, I'll admit I can't climb a tree; or at least never had to. I am willing to take my chances with the wild things of the forest-and right here, I want to dare any old grizzly bear to cross my path." 
"And I'll extend that dare to all the wild things in Wyoming," added Bill.

"Yes, gents," smiled the Pullman porter, "if you will let me now, I shall make up the beds and you can be in the sweet land of dreams."

Bill and I then went to the other end of the train, and awaited the making up of our berths. Upon returning we went to bed for the night.

\section{CHAPTER III.}

August the twentysixth, nineteen

seventeen.

The Burlington train on which the two young men were passengers had been rocking along at a monotonous speed since Friday, the twenty-fourth; and while they enjoyed all of the comforts of travel, they were mighty glad to be advised by the porter that they were to prepare themselves for Billings, Montana.

"Yes, sah, this hea' am Bullens," proclaimed the yellowfaced fellow, with a laugh in harmony with the jingle of two reasonably good sized coins he had just procured.

The two young men stepped off the train eagerly. They were anxious to stand upon such a Western spot and breathe the fresh air of the West. This they did.

After canvassing the town, as to the best place to eat a large breakfast, and after finding the principal hotel still closed for the night, Percy and Bill placed their knees under a table in a restaurant and enjoyed the fat of the land to the extent of grape-fruit, oatmeal, ham and eggs, toast, coffee and wheat cakes.

"Well," said Percy, as he expanded himself in proportion to the breakfast he had just eaten, and struck a match to his pipe, "that should hold us until dinner time, anyway."

Shortly afterwards Bill and Percy boarded a shabby train 
with several wheels long worn flat. They bounced along over the prairie country until they reached Frantic. When the young men had finished taking a good look at that town they decided that it had been well named, and soon as possible they boarded another "flat-wheeler" for Cody, Wyoming.

We passed through a great expanse of country. There appeared a number of green spots-irrigated farming was fast turning the wilderness into a veritable paradise. In the distance we could see the Rocky Mountains.

"The country is growing more interesting in the distance," said Bill; "I wonder what sort of game live in those mountains now ?"

"I understand we are to see, and right shortly. Isn't that Cody across the river?"

The train rattled up to the station about a mile or so from what appeared to be a collection of buildings, which were upon the townsite of Cody, Wyoming.

"Cody!" shouted a leather-voiced brakeman.

I looked out of the car window. I saw three anxiouslooking individuals and a few other people. The anxiouslooking young men were close to thirty-five years of age. A plump sort of a fellow, about five feet ten inches tall, with large blue eyes, and a florid complexion, looked a little unnatural in his high Stetson hat; while another, a well-built, black-haired, soldierly young man, not yet thirty-one years of age, with keen black eyes, wore a soldier's uniform. While the third, a well-sized young man, appeared to have relaxed into the ways of the West, and yet a critical examination would reveal that he too, still possessed a trait of the East. The three young men got on the car.

"Well! My friends! Floyd and Joe," shouted Bill, as he caught their extended hands.

"And this is my friend Percy," exclaimed Floyd.

"Yes, Floyd and Joe, meet Percy Field." Floyd and Joe grasped the hands of their friend, Percy, as they turned to meet another genial sort of fellow.

"Percy and Bill, this is our friend, and your guide, Bill: 
this is Hal-Hal Evards," and everybody shook Hal's hand, and we blocked the doorway so that the other two passengers had to go out the back way. On becoming so well acquainted we all got into Hal's automobile and started for Cody and The Irma Hotel.

\section{CHAPTER IV.}

We arrive at The Irma Hotel. Our trunks are sent to us there a little later. We are booked for dinner.

This hotel is maintained by a daughter of Buffalo Bill-his daughter Irma, a comfortable looking woman of possibly, shall I say thirty summers, for the daughter of Buffalo Bill? At any rate, however, as she has almost passed the age to play the part of an extremely youthful heroine in literature, I shall have to leave her to preside, and preside with dignity, too, over The Irma Hotel.

This hotel is located on the corner of two of the principal streets of Cody. It is a commodious two-story frame edifice built in keeping with the town, yet a little better than the town could have had had it not been for its namesake, the Honorable Colonel William Cody. On the south side, and immediately abutting upon the street, is a large porch, where, during good weather, a great many hunting stories may be heard; while on the other side, a shoe stand and The Irma Bar.

The walls, desk and almost every available space in the hotel and bar, and in fact the entire town of Cody, are decorated with pictures of the Honorable Mr. Colonel William Cody. The walls of The Irma particularly abound with his pictures. There you can see pictures of the Honorable Mr. Colonel William Cody as a young man; an Indian fighter; a middle-aged man; the pictures of him as a man late in life; a writer; a show man; a conqueror of the prairie; and a picture in a pose denoting almost every other 
kind of a Western hero. What little wall space there remains is covered with game trophies.

We strangers from the East had dinner and spent some time in studying the pictures and trophies.

"Thereare some fine trophies in the barroom," suggested Hal.

We then went to the barroom of The Irma Hotel. It is one of easy access to both the outside world and the hotel. I counted four entrances to it. From the size of the crowd that patronized the place, I could readily understand the necessity for the number of doors; and from some of the patrons, why the large front and back doors.

Of course, while enjoying the various works of art on the walls, and game trophies, it occurred to one of our party that our space required the purchase of some token of affection, such as a drink of some sort; and, as the crowd was composed of two very temperate young men from Kansas City and two equally as temperate from the prohibition state of Kansas, it can be easily imagined what we had to drink.

"You dudes," shouted Hal, "had better stop your drinking lemonade, soda pop and such, and go and pack your war bags. We have a long trip before us, and the boys at the ranch are impatiently awaiting your arrival," interrupting a discussion over the bar of the largest bull elk ever killed in the mountains.

"War bags, what are they?" inquired one of the dudes. "And what was that pretty little name you called your newly made friends, Hal?" asked Percy, as he finished his lemonade.

"Dudes," added Hal with a smile. "Dudes, that's what you will be called out here. In Montana they, the natives, call the hunters sports; here we have another namedudes. In fact, to be a dude out here isn't so bad; and, rather than dub you tenderfoot, or sport, we folks out here in Wyoming just call you dudes-we call the lady hunters, dudines; and your party, a dude party, and the guides, dude wranglers." 
"And we tough-looking, rough-looking boys-in fact, I am inclined to say ornery looking individuals-are to be known as dudes? What a pleasure it is to know ourselves as others appreciate us," spoke one of the dudes, concluding: "Hal, my dear friend Hal, can a dude buy a drink of -now, let's see, what is a dude supposed to buy?"

The dude was informed that that privilege still remained, and was almost expected. In fact, he was expected not only by the bartender and flies-and here I mean, to buy for the bartender and to buy for the flies or hangers-on. So it was that the dude who suggested, out loud, and, as I remember it, it wasn't so loud, either, was given a chance to buy; and to make quite an extravagant purchase, too, for it appeared that he was the box agent at a circus, which had been well advertised, from the number who gathered around him.

The dudes, however, were well pleased with the venture, as it brought so many of the hangers-on out from the walls that it gave a better view of the trophies and pictures of the Honorable Mr. Colonel William Cody.

"Say, if you dudes don't hurry, we'll be caught in the dark-of course, it is all right with me, but I am anxious to get started. You know we have a thirty-mile drive ahead of us-up the Shoshone Canon-and you dudes had better pack your war bags," repeated Hal, seriously.

"Pack our war bags for thirty miles up the canyon?" interrupted one of the dudes.

"Oh, no," added another, analyzing the situation painstakingly, and without any need; "you see, my dear dude, you pack your war bag and put the bag in the car, and then the car packs you and your war bag, see! Precisely so."

"Of course," laughed another dude, as he stepped to one side and permitted a rough sort of an individual to get up close to the bar.

"Yes; and certainly you see," he interrupted, and added, wobbling slightly: "Let us have a-n-o-t-h-e-r, and another. Let the car pack the war bag. Ha, ha! Let the car pack 
the war bag! It can do it as well as a mule, and Gawd knows a mule can. Say, Steve!" said our newly made friend, as he called a thirsty-looking person. "Want to ask you a question; hick-up, hick! Can a mule pack a war bag?" Steve didn't seem to care as much about packing a war bag as a drink, and quite aptly ended the argument by suggesting that he thought his friend was going to buy a drink.

"Here, Mister Bartender!" Our newly made friend pounded on the bar for an audience. "My dude friends, and a roughneck," pointing to Steve, "and myself want a drink. If you are damn quick about it you might take two yourself-the quick-er I get you drunk the cheaper it will be for me, and my dude friends-so, gentlemen, roughnecks and dudes, what will yer pleasure be?"

The dudes suggested that they would take the same as before. The hospitable stranger told the bartender that he would have WHISKEY, with a thump on the bar that almost bounced the glasses off of the bar, and the nose of the bartender, while the other friends suggested unmistakably that they would take the same. They poured it out of the bottle themselves until their glasses were full to the brim at twenty-five cents per glass.

"For the love of Gawd! You are a queer lot of dudes!" our new host added in astonishment, as he drank with one swallow his little needed drink and surveyed the soft drinks of the dudes.

"Say, stranger," put in Joe, after Hal had made another suggestion, "we have to go now," and with a smile, "If we don't see you again-well, when we meet you, it will be soon enough. Good-by."

The dudes hurried away to pack their war bags. There was the neatly packed trunk of Bill and the neatly packed trunk of Percy. Their wives had packed these trunks, oh so neatly. Everything was in its proper place. It would be a shame to destroy the neatness of these trunks; yet Bill and Percy were in a hurry. They had been urged to hasten any number of times by Hal. They opened their trunks 
and took out their hunting clothes and put them on. As these war bags were to be carried on the backs of mules, and their contents would be thoroughly mixed by the movement of the mules, Joe held the war bag of Percy open, and Percy picked up the tray of the trunk and poured everything which was in the tray into the war bag, and in like manner picked up the trunk and emptied it into the war bag. His citizen clothes were then carefully folded and placed in the trunk and the trunk locked. It was then ready to be carried to the trunk room of The Irma, where it would remain for the next month. After doing this, Percy sat down on his war bag and lit his pipe and smoked. Bill had just started packing his war bag. He was wondering where he could put his various necessities, when $\mathrm{Hal}$ told him that it would take about forty mules to carry his outfit into the mountains. The two, Bill and Hal, then sorted his necessities, which were far less than Bill had thought, and put them in the war bag of Bill.

"Aren't you dudes ever going to get your war bags packed?" asked Percy, as he calmly smoked his pipe, adding between puffs that he supposed as the guide was in such a rush he expected the dudes had better pack their war bags downstairs. Floyd, Joe and Percy, and in the course of a short time, Bill, swung their war bags over their shoulders and started downstairs.

When Percy reached the first floor, he was met by his newly made friend, who had bought a drink for practically all of Cody and the dudes.

"I say," sputtered this friendly fellow, as he placed his hand upon the shoulder of Percy, "shall we have another drink before you go? Or shall we have several? It will make the long ride easier, and your nerve a trifle steadier. Say, boy, don't you know you are out where the West really begins? Come on!' he added, giving Percy a friendly nudge. Hal.

"Oh, come on! Percy. Bid your friend good-by," shouted 
"Now, aren't you the dude?" added the thirsty one, squinting through a pair of bleared eyes, slightly unsteady on his feet. "Well, if I were the dude, I'd tell that smart chap to go to hell. Come on! Let us have a-n-o-t-h-e-r!" Percy thanked him for his generosity and stepped out of the door and into the car.

Joe was stopped by the same individual, and Bill and Floyd, and in this way all of the dudes were tempted by the greatest enemy of the West.

The people of The Irma Hotel came out onto the porch to bid the dudes farewell. We shouted them a fond adieu as we drove away.

\section{CHAPTER V.}

We turned the car around and drove up Main street. On our way we were hailed by a messenger, who ran out from the curb. He informed Hal that we had broken a spring. We stopped. The mechanics of Cody gave a hand. They brought out from a garage a clamp which they put on the spring. This clamp was a temporary repair, yet it held the leaves of the spring secure. While this mechanical work was being done, the dudes thought of something they wanted and went to the drug store.

"I think I want to take alother fishing pole with me," spoke Floyd, as he interrupted a pleasant man, the proprietor of the store whom everybody appeared to know by the name of "Doc," and whom we rather envied for his fishing experiences.

"A what?" shouted dude Bill, peevishly. "A what? Surely, my dear Floyd, such a sport as you are will not dub the fishing rod with so common a name."

"Oh, no, far be it from me to do such a thing as that," replied Floyd affectedly, "but I must confess that the language of my youth still remains a part of me, and while I 
enjoy fishing and hunting and sporting around with you dudes, pardon me if I do not use the proper lingo, my dear Bill-now, what is it that I want?"

Bill said something about a fishing rod, while Percy suggested that Floyd could use one of his; and Doc, not particularly enjoying the idea of Percy permitting Floyd to use his fishing rod, turned on the victrola, which presented a full jazz band on parade. Bill, of course, was fond of music and a jazz band and decided that we should take the victrola with us so that we could have the jazz band in the far away mountains; and Doc, not having sold the extra fishing rod, didn't think it would be a bad idea. Bill was just in the act of buying the victrola and all of the records necessary for our pleasure, when he was reminded that everything we took with us had to be carried on the backs of horses and mules, and that, perhaps, under all circumstances, we could get along just as well without the jazz band and the victrola.

"Let us have an ice cream soda," cried Floyd, "it may be the last one we will have for some time." The invitation was accepted by all of the dudes and Hal believed he would take, what he called, a double sundae.

By this time a cold rain had begun to fall. The road was getting slick, yet away went the motor car and the dudes on a most perilous ride.

"What is the river, Hal?" shouted Percy.

"The Shoshone-Big Stinkum, as the Indians called it." When we dudes got a whiff of its sulphurous odor we could quite readily understand why it had been so named by the Indians.

The motor car proceeded to toboggan down a hill which the dudes thought was the sicepest they had ever gone down in their lives in an automobile without chains on the wheels.

"Don't you think we had better put on chains?" shouted one of the dudes nervously.

"Oh, I think we can make it," replied our driver. 
"You think?" gasped another dude.

"And what if you don't?" thought another. Yet what cared the dudes for the perils of the road. They were on their way to the mountains in search of big game and were willing to give what they must.

We struck the bridge at the foot of the hill safely and drove on through the foothills. These foothills were sparsely covered with sage brush and bunch grass. We drove on up the canon into and between two mountain ranges which formed the banks of the Shoshone river.

After almost sliding off the top of any number of high ledges and falling into the Big Stinkum river, and probably Kingdom Come, we stopped and put on our chains. By this time, however, the sky had cleared, the rain had ceased to fall and the air was fresh and cold.

"Hal," shouted one of the dudes as loud as he could, so that he could be heard over the roar of the Shoshone river, which rushed by and down, "what is the name of that old pile of rock, which looks as if it might be inhabited by rattle snakes, and any number of man's most deadly enemies?"

"That's Rattlesnake Mountain. I was particularly anxious for you dudes to get an early start-the travelers, dudes and tourists say that this is one of the most beautiful drives in the world. On ahead is the Shoshone dam. I think it is one of the wonders of the world; and, perhaps, you have never heard of it," announced Hal.

Here we met a Ford car, full of tourists. We lost our breath when we saw how close to the outer rim of the ledge its wheels went.

"Gee," cried Floyd, "driving in this canon gives a fellow the creeps."

"Yes," laughed Hal, "and especially when you meet a green driver-yesterday I met one, and he just stopped on the brink, and almost sent himself and family on that long, long journey. I had to back several hundred yards down before I could find a place for him to pass." 
We then came to a place where the distance between the mountains became very narrow. The Shoshone River roared as it passed through the tunnels made in the mountains, which had been provided with the construction of the dam, so that the amount of water maintained in the lake ahead of the dam could be regulated; and from its roar a traveler could easily imagine there was a storm brewing on the other side of the mountains. We followed the road, which had been cut out of the rocky sides of the mountain, in places through tunnels, until we saw the Federal Dam. We stopped our car, and ran it into a small cutout in the side of the mountain, which had been made expressly for the purpose.

We saw an immense concrete dam, reaching across the expanse between the two mountains, which formed the banks of the Shoshone River, damming the river, so that a wonderful lake of cold, pure water was formed ahead of the dam, the dam being above the sulphur springs.

From the natural conditions-the way Nature had left the river and mountains originally-it appeared as if everything had been especially planned for this masterpiece of man's handiwork. Ahead of us, and on the other side of the dam, the mountains stretched forth and made room for the Shoshone Lake.

"How immense," shouted Floyd, "is this dam!"

"Let us go onto and across the dam," cried Joe.

As we approached the dam Percy saw a sign which was placed there by the Government, and read aloud, as if he were thoroughly informed as to the facts.

"Floyd," said Percy, "this dam was placed here by the Department of Interior of the United States Reclamation Service. It is the Shoshone Dam. Think of it-it has a height of three hundred and twenty-eight feet; a thickness at the base of one hundred and eight feet; a thickness at the top of ten feet; and the length across is two hundred feet. It has a capacity of four hundred and fifty-six thousand acre feet, with an area water service of ten square 
miles. It has a maximum width of four miles and a maximum depth of three hundred feet. The work on this dam began November, 1905, and was completed in 1910. It cost us, our Government, $\$ 1,354,000$."

"Thanks, Percy-for a minute I thought you were right smart on the wonders of our country, but I see you have merely been reading the sign," said Floyd, giving Percy a friendly kick in the seat of his trousers.

"Say, Hal," shouted another dude, "is this dam in use?" Hal informed us that it had never yet been used.

"Let us walk across the dam," suggested Joe. Everybody started across. We then walked down the long, long flight of steps, which led to the base of the dam. It appeared as if we would never get down, and when we finally did, we thought we would never get up again. Our hearts almost stopped beating from the exertion.

We got back into the motor car and drove on. The way from the dam to the ranch, our destination, was not so steep. The pass widened. On one side lay the Shoshone Lake, and approaching it from both sides were vast grazing slopes.

We drove on until we passed Wapiti postoffice.

We stopped at Frost and Richards's ranch, and there we met the justice of the peace, an Honorable Mr. Justice Foster. The Honorable Mr. Justice Foster, justice of the peace of Wapiti township, Park county, was a pleasant man. He had a pleasant job for the Honorable Mr. Justice Foster. It was the writing of alien hunter's licenses for the dudes. These licenses gave the dudes the privilege of hunting in certain localities of Wyoming-stating them, providing we were accompanied with a guide each; and for this high and important privilege we paid the Honorable Mr. Justice Foster the sum of fifty dollars apiece. The Honorable $\mathrm{Mr}$. Justice Foster, having received a new fifty-dollar bill from each dude, introduced us to his family and friends, who were there, and after they had wished us a great deal of success he wished us equally as much luck. 
We were told to keep the licenses and to present them to any game warden who might desire to see our credentials.

After attending to these matters of state, we climbed back into the automobile and drove on. We arrived shortly at the homestead of Mr. Hal Evards. Here we were met by his mother and wife, both very charming women. They suggested that we had better have a little drink. We did. It might have been cocoa, and it might have been tea, but whatever it was, it was taken with due appreciation. While enjoying the drink and showing our gratitude, Hal left his living room, a mighty comfortable place, and went to get some dishes and cooking utensils which we were to take with us on our trip; and, after each dude had nearly smothered the hostess with his appreciation of the said little drink, we looked about the room and found it to be full of trophies. We admired these very much, and upon the return of Hal, were assured that we would doubtless have equally as many to take home with us after the trip.

The mother of Hal seemed to know more about the necessities of the dudes than the dudes, and after going over their various needs, inquired if we were all warmly dressed.

"Well," said she, in a motherly way, "I always like to have my boys dressed so that they can stand the weatherkeep a boy warm and well fed, and he will be all right in the mountains."

We assured her that we were, and after $\mathrm{Hal}$ had told us that we would be very well fed, as he had attended to that himself, we bid the family good-by and started for our final drive for the night.

We drove a mile or so on up the canon. We turned to our right, and turned into a large gate, which led into the ranch of Freeman and Shull. This road leads to the ranch house. It wound its way through the ranch. In places the road was very narrow and rutty. We were going down a slight incline. Our front wheels were in a rut. Our driver tried to turn out and was very much surprised to find that the steering gear of the car would not work. 
"What's the matter, Hal ?" shouted Floyd, as he got out of the car.

We all got out and found that the steering knuckle grip had pulled off of the bar which turns the wheels.

"My, how lucky we are that this did not happen when we were going around some of those high ledges," shouted Floyd. We all felt that we were exceedingly fortunate. With aid of a monkey wrench and a box of matches the machine was repaired by the dudes and we drove on through the dark. We had fairly good lights on the car, yet it was very dark and the road turned so much that the lights were of little use. Of course, Hal knew the road. We drove on, and after climbing a very steep hill, and turning a very sharp curve, we were greeted by the barking of a dog and a friendly but gruff salutation of $\mathrm{Mr}$. Hardy Shull.

"Here are the dudes, Hardy," shouted Hal.

"All right-glad to meet you, dudes; get out and spend the night. Hal, take 'em to the bunk house-oh, yes, everything is ready-we'll get away from here about five o'clock in the morning," added Hardy, laughing; "the boys are all asleep. Hal, find the dudes a place to sleep," said Hardy as he turned and went to bed.

We were then conducted by our guide to another portion of the ranch yard, and into a low two-roomed log cabin. A lamp was lighted.

"Here, there, Shorty-the dudes," shouted Hal.

"Glad to meet you," cried Shorty, as he raised up in bed. "Dudes, you are a little late for an introduction, I'm Shorty Kelley; that fellow over there, who is still asleep and snoring, that's Ed, the cook. Ed, you old - wake up here and meet the dudes. And that fellow over there is Hurricane Bill."

"Now, guides and roughnecks-all friends of ours-I want you to know our names," shouted Bill. "This is Jae, Joe McCandless-boys, you have my permission to call him 
Joe ; and Percy, Percy Field; Floyd, Floyd Hipple; and I am Bill, dude Bill. We are to be all boys together-Bill, Floyd, Joe, Percy-Shorty and Ed, Hardy, Hurricane Bill, Hal, and all of us."

"All right, Bill," added Shorty, "you and Percy take that bunk over there; and Joe, you and Floyd that one over there; and Hal, you will find a bunk over there," and with this suggestion Shorty tucked the covers around him and did nothing more until morning excepting snore.

In a very few moments, and with no more to do about it, the dudes went to bed, and being tired, were soon fast asleep.

\section{CHAPTER VI.}

Morning came right away. The dudes got up, dressed and washed-washed in a wash pan out of doors in the cold, fresh air.

"Here, you dudes, come and get it before we spit in it!" was the summons we had to breakfast. It was a breakfast of oatmeal, coffee and ham and eggs; and large, thick slices of ham and as many eggs as any dude could eat-potatoes, hot biscuits, butter and preserves, and milk for those who liked milk to drink. The dudes ate until they were well filled and Bill passed around some cigars. The dudes proceeded to fill the kitchen and dining room of Mrs. Hardy Shull full of fine smoke, while the guides pulled their chairs back with a snap and ran to the corral. During our breakfast, Mrs. Hardy Shull presided. She was a good looking, redheaded young mother of possibly twenty-five summers. She waited upon the table and her beautiful baby girl; while Hardy acted as cook and head waiter.

The dudes made a fuss over the baby-they all vowed she was the sweetest little flower of the West they had ever seen; and then Mrs. Shull smiled, while the dudes excused themselves and stepped out into the great out of doors. 
We found the ranch house resting snugly on the slope of a mountain, and to the left of it, the bunk house. Between the bunk house and the ranch house ran a beautiful little mountain stream of cold, fresh water. Back of the ranch house stood a range of sorrowful old gray mountains, which appeared to be grieved over the fact that they were not as stately looking as the ones across the valley.

From the front platform, or porch, of the ranch house we saw a number of horses in the corral-a number saddled, and Shorty Kelly hustling around with all kinds of business. Hardy was busy, too, and so was Ed, and it was with a great deal of pleasure that we watched these men work.

There were twenty-seven animals selected to carry the dudes and their provisions into the mountains. We were assigned to our horses according to our weights. Percy drew a large gray horse, Floyd a buckskin pony, Bill a gray and Joe a sorrel. The other horses and mules were used as pack animals. Of course, Hardy had his black horse; Shorty, a big rangy heavy animal; Ed, his pretty little mare; and Hurricane Bill, an Indian pony.

In the course of an hour or so we were mounted and with one loud hurrah we started from the ranch for parts unknown to the dudes.

It must have been amusing to see the dudes mount their horses. All of them had ridden more or less in the low country, but no bronchos. They had ridden for an hour or so, or a half hour, but not all day. At any rate the dudes were able to climb upon their horses without assistance. We were soon traveling toward our happy hunting ground.

The morning air was fresh and invigorating. The sun shone brightly and everything appeared to be happy and gay.

We rode up the Shoshone canon all day long. We were going into the vicinity of what is commonly known as The Jackson Hole country. 
"Hal," asked Bill, as he rode up close to him, "why is it that this country is commonly called "The Jackson Hole country?"

"Well," said Hal, "in what the old timers out here called 'the good old days,' there was a bunch of bandits who lived and operated in this district; they did their raiding down in the low country and then took refuge in the mountains. Old man Teton Jackson was the ringleader; he 'holed up' there-it was his hole; and ever since it has borne his name."

Just then one of the pack mules took a notion to depart from the train and Hal spurred his horse on over what looked to be such a precipice that one of the dudes thought we were going to lose one of our guides, while another dude, to strengthen his nerve took the same plunge and after a rough ride landed safely near the bottom of the hill.

Ed rode ahead of the line. He led a mule and all of the other animals just naturally fell in line and on we went to the music of the guides and Shorty Kelly, the horse wrangler, as they used a little cow rhetoric on the pack train.

While Shorty, early in the morning, had dressed for dinner, breakfast and all day, it may be pleasant for us to consider him and his attire.

There he stood on his toes. It seems he was always on his toes, in high heeled boots, with spurs almost as long as his feet, "rearing to go." Of course these spurs were dear to his heart, having been presented to him by one of his millionaire friends, another dude; a pair of corduroy trousers, stuffed in the sides of his boots. He wore a hickory shirt. He covered the back of his head with a large Stetson hat, big enough to use as an umbrella, and tall enough to make a short legged man look imposing. Shorty was well muscled. He was all shoulders and arms; and while his legs were long enough to "bounce about" anywhere, and everywhere, with agility, yet it appeared, from a casual observance, that they were not long enough to sit astride a 
horse, yet Shorty was a horseman, through and through, and rode the highest and biggest horse in the pack. He had a very pleasant voice-could sing or swear with equal versatility; and had the reputation of being able to shoot a gun with such accuracy as to take off the lower joint of the ankle of a gnat at, say two hundred yards, without ever disturbing the upper joint of the said gnat. He was originally from the East, but with him it had been so completely swallowed up by the West that I don't think he could ever again be claimed by the East, excepting as a hero. He, like a good many other heroes, had come from there in his youth.

We jangled along the road which led up the canon. We crossed the Shoshone River and followed a shelf on one side of the mountain, used as a road. Sometimes the rock of the mountain overhung the road, and it would make one feel dizzy to look and see immediately above him an overhanging mountain. Whole sides of the mountains appeared to be leaning, and about to fall; yet they have stood the strength of the ages, and from their massive appearance, have a fair opportunity to remain unmolested for any number of centuries, yet, they, like everything, shall in time disintegrate.

Immediately below us ever rushed the river, hissing, boiling and dashing itself against the rocks.

Across the river we could see every now and then snall ranch houses and a strip or so of irrigated land. As the road led by the river the valley narrowed and the mountains became very rugged.

We rode and followed the pack until noon. We dismounted and the dudes were served with a lunch, whion consisted of a large home-made bun, bacon and cheese.

Notwithstanding the fact that the dudes had eater : heavy breakfast, it being well displaced and digested by their ride, they were ready for another meal. It was a little harder for us to get off our horses at noon than the getting on them in the morning, yet we were only beginning to feel 
the effects of the ride. We all took a long drink out of the river, ate lunch, and remounted.

All along the road we found places which the state had provided for tourists to camp, and about them there were signs, suggesting that those using the camp sites be good woodsmen and put out their camp fires.

This road which we were following led to the southern entrance of the Yellowstone National Park. There were any number of automobiles passing from both ways, and now and then a big yellow tallyho of an automobile would come dashing down or up.

"Of all the wild drivers," shouted one of the ciudes, as a big car dashed by, hardly slowing up to insure the safe passage of our pack train.

"Here comes another!" cried a dude, nervously.

It appeared to us that they were rubbing it in on the guides and horse wrangler.

"Let me have your gun, Bill," shouted Shorty, "I'll fix these —_ , if they can't pass our pack right. Some of these —_ tourists think they own the whole state of Wyoming; by G-_, and Shorty jerked out a high-powered rifle and awaited the oncoming machine, while the dudes awaited whatever would happen. It came to be, however, fortunately for all parties concerned, that the driver of this car was a gentleman and he drove up and stopped and gave us plenty of time to get our pack by.

On the stopping of the car out bounced a well-tanned somebody, who looked something like a man and something like a woman, with a kodak, and proceeded to snapshot our party. She satisfied herself by taking our pictures. One of the dudes then-I won't say which one, as I might mean each one-threw her a kiss, while the said individual, upon such a salutation, put her kodak upon the running board of the car and proceeded to bring smiles to the pack by using both hands in throwing back what I presume was her appreciation of our greeting.

Shorty replaced the high-powered rifle and removed his 
hat, blushed to his ears and bid the individual a fond goodbye.

A carload of fat Jews passed, and any number of Fords bounced along, all shaking and rattling the store teeth of a number of old, sunburned faces. These faces bid us good cheer and were pleasant to encounter and study; yet they were becoming a pest, for each time some of our mules would leave the pack, and the horse wrangler would have to get them back in line.

We rode on around and through the mountains and the canon, using this automobile road, which was in very good condition. It appeared that every time we would go around a good-sized mountain we would run into a different kind of weather. On one side of the mountain the sun was shining very brightly, while on the other it was raining, and yet, when we would go around another, it would be sleeting, and then we would come back into the sunshine. Ther were any number of storms blowing up and down this canon.

The dudes were constantly changing their clothing, putting on and the taking off of their hunting coats, their leather coats and raincoats, while the guides and horse wrangler rode along upon their mounts and enjoyed themselves to their fullest extent, the ride and their ability to swear.

"That was quite a rhetorical expression," suggested one of the dudes to Shorty, after he had called a mare mule almost everything bad in the world for leaving the pack and chasing up the side of the mountain.

"A what!" shouted Shorty, somewhat exasperated.

"A rhetorical expression," repeated the dude, continuing. "Doubtless, my dear Shorty, you believe in hyperbole, or taking advantage of such when speaking to a mule."

"Oh, yes," added Shorty, smiling, "we believe in using a little power now and then."

Shorty, Hurricane Bill, Hardy, Hal and Ed rode along with the ease and comfort of experienced horsemen, but 
the dudes-well, the dudes constantly shifted their positions from one side to the other, riding with first one leg over the saddle horn and then the other, vainly searching for the easy way, which comes only from experience and practice. Percy vowed that his ears would be sore from the ride, while Floyd suggested that he possessed something else, which was nearer the saddle, that bothered him more than his ears.

Our ride up the canon led us past the Palisades of the Shoshone. These Palisades are imposing walls of brown stone, which have been formed by the winds, rains and snows of the ages, so that they resemble, if you would be kind enough to draw upon your imagination slightly, ruins of old castles and fortifications. There they stood, and shall stand, for the centuries to come.

We also passed a mountain which had an opening in its top; this we were told was called "Window Rock."

We rode by another mountain which stood uniquely in our minds, in that it possessed something different from any other section of our country, or any other portion of the world, as far as that is concerned-it maintained a holy city. This holy city stood high in a mountain pocket-far, far away from harm, and the jibes and jeers of this old wicked world. The elements had so cut and carved the rock that it resembled a great cathedral where an innumerable throng worshipped silently, ever standing or kneeling as their creator intended, never joining in that great amen ever chanted mysteriously by the wind.

Leaning tower stood on ahead of the dudes. It looked as if it might topple over at any minute.

"Do you see that leaning rock over there, Joe?" said Hurricane Bill. "One night there was a cow puncher, who had a 'wee drop too much' - he put a log up against it and propped it up, and then hurried on to Wapiti and told his friends that the mountain was falling over and would have had it not been for him propping it up."

On up the canon we rode until about 5 o'clock. We en- 
countered all sorts of weather, rain, hail, sleet and some sunshine. All of us were chilled to the bone.

We arrived at what is commonly known as Libby Flats. Libby Flats are a number of pieces of flat ground of a valley located between the two mountain ranges. This is a very good place for grazing. Here we pitched our camp, which consisted of our piling our luggage under a tree and the setting up of a camp stove. The guides and horse wrangler unpacked the mules and horses and put our beds on the ground. Ed assembled his camp stove, which looked like two cracker boxes, sitting end to end upon each other, with a stove pipe in one end of one of the boxes. He was very busy getting supper. In the course of much swearing on the part of the guides and horse wrangler, as they unpacked the pack train, and a great deal of stirring about on the part of the cook, dinner was prepared.

Our dinner consisted of clam soup, bacon and eggs, bread and butter, pickles, corn and coffee. The bread was in the shape of large hot buns, reasonably well cooked. On these buns we piled a lot of butter and jam, and with the soup, bread, eggs, bacon, corn and coffee, we had a good dinner. It was served in tin pans-some of it, hand to mouth.

A short distance from our camp lay what is known as Holm Lodge. This is a summer place. The altitude here is approximately seven thousand five hundred feet above the sea level. The air tonight was cold and chilly; and thie dudes, being slightly shivery, readily acquiesced in the suggestion of one of them-and I'll not say which one, as I might mean each one-that we have a "wee touch of something warming," which he poured out of a bottledoubtless for the purpose of counteracting the altitude and the dampness. The "wee touch," having before dinner met with such universal approval, was again served at the close of the festivities-so it came to be that the dudes quickly forgot that they had ridden all day-had been very tired and sore-and promptly accepted the suggestion of Hurri- 
cane Bill that we go up the road which led to Holm Lodge. and see what was going on there.

We went to Holm Lodge under the chaperonage of Hurricane Bill. We found Hurricane Bill to be quite familiar there, upon being escorted by him to that rendezvous.

The distance wasn't very great, yet it was all up hill and at such an altitude that it was a great effort for all of the dudes. The dudes, however, were an adventurous sort and pushed on, regardless of what might happen to their hearts. They had left their sweethearts at home, so what cared they for their hearts.

We found Holm Lodge to be a very large log cabin. One end of the cabin was furnished as a general assembly room or lobby. It had a large fireplace, over which hung the mounted head of a bull elk. The walls were covered with trophies. The lodge also had a pleasant porch and at one corner of the porch was a spring of cold, pure water. Around the lodge were a number of tent houses, which accommodated the summer folk at bed time.

We walked up on the porch. Upon looking through the window of the lodge we surveyed the situation. We found in the far end of the lobby the immense fireplace and its cheerful rays illuminated the faces of a crowd of summei people. They appeared to be enjoying themselves very much.

The door of Holm Lodge was fastened, and locked at night, by an elk horn lock. The handle and the lock were all made from the horns of elk. Its latch string was always hanging out to Hurricane Bill and his friends. - We walked in-all of us carrying large caliber revolvers, dressed in the roughest possible costumes.

The four dudes and Hurricane Bill made themselves at home and took charge of the fireplace. My, but it was warm and comforting.

Everybody was enjoying the songs of a young lady who performed at the piano.

We were introduced to the hostess, a Mrs. Young, and 
then, having become so very well acquainted with Mrs. Young, by the introduction of such a distinguished character as Hurricane Bill, Mrs. Young told us that they were in the act of giving a dance and that she would be delighted if we would take part in it. She then introduced us to all of the guests.

Of course, the dudes all could dance even though they had ridden all day on horseback, and their bones and bodies ached; yet under all of the circumstances, they felt they should do their part, especially as Mrs. Young, a friend of Hurricane Bill, had so requested them.

The pianist struck a very lively ragging one-step and the dudes with their partners stepped of $f$ with vim and vigor.

The first dance was a sort of a race. It was wild and furious. The dudes and the summer folk puffed and blew, both on account of the dance and the altitude. Their efforts brought the bloom of youth to the faces of each while down their cheeks ran large drops of perspiration.

"Yes, Miss —_, said one of the dudes, as the said Miss, a very charming young personage of possibly twenty summers, was escorted over to a chair by a pleasant but puffing dude, "I really enjoyed the one-step, and you!" he added, as he mopped his brow.

"You did?" she said and smiled, as she looked as if she realized the truth of his expression, but doubted his sincerity; yet, notwithstanding, was going to accept the same and appreciate it.

"And where are you from?" asked the dude. She told him that she was from New York. The dude vowed that he had always found New York to be a grand old place, and that while pure mountain air was one thing, the bright lights were another-she was a long ways from home, and out there in the wilds, someone should watch her step, and it might as well be her newly made friend.

Right in the midst of four particularly blissful moments, when the four dudes were enjoying themselves to their fullest extent, the hostess stepped in the center of the room 
and announced that we would have an old-fashioned Virginia reel.

The reel proceeded with fury. When all of the summer folk and dudes were completely out of breath, it was suggested that everybody gather about the piano and sing; so the party, being out of breath, whispered the ragtime words of "I'm From Dixie," until they were in breath, and then with a determined effort to please, almost shook the trophies from the wall.

All of this time there was a very dignified old gentleman, with a long, grizzly beard, sat by patiently. He stroked his beard and looked very much as if he didn't approve of dancing. In fact, he looked as if he didn't approve of a great many other things and especially one of the dudes. Being so disposed he soon fecl asleep and upon being suddenly awakened by a high note of one of the apparent songsters, almost fell out of his chair: and he, having done such an undignified thing, and having committed such an outrageous social error, gathered up himself, and what remained of his dignity and started to bed. He didn't go until he had called one of the charming young women from the floor, very much as if she were still a mere child. The young woman explained to her father that she was going to dance "one more" dance and then retire; and the father, upon receiving such a satisfactory explanation, said goodnight and went to bed.

"And is he your father?" asked the dude, rather astonished.

"Yes, and a perfect dear, too! Yet he is getting a little old. He has forgotten how he used to dance and enjoy himself-but he is so good to me; and when he isn't tired he is such a good pal. We go everywhere together."

The dude, of course, was glad that the man with the grizzly beard was not her husband; and upon his telling this to her, she laughed in a jolly way and gave evidence to what some may call the pearly teeth; the enchanting eyes of blue; the slightly tanned pink cheeks: and as she coyly 
winked behind a dark eyebrow and pertly curtsied, showing the top of her well-dressed bundle of black hair, she told the dude that he was so rough and tough looking that she had really begun to like him. This made the dude realize that he was a married man and, as he blushed through his smiles, he was cautioned by another dude who was doing the same thing, that he had better watch his step. Of course, all of the dudes did.

"I suppose you boys are hunters?" she said earnestly.

"Nope, we are dudes," replied the rough-looking individual.

"And aren't you?" she added, smiling; oh, so sweetly.

"Suppose we are-that's what they call us-and after bouncing all day on that broncho of mine I feel I'm not much of anything."

"Oh," said she smiling, "it might be the altitude. Do you feel a little faint? Or as if now, let's see-I've some of what I carry for father-would a mere dash of it please?" and then she smiled so sweetly that the dude rather envied her father, and suggested that there was plenty of water at the spring at the corner of the lodge. From that time on this particular dude was able to cope with the altitude and all his surroundings.

"Do you see that column of smoke over there?" asked the dude, after having directed his companion in that direction. "That is our camp-and tomorrow we leave the beaten path, and most of the world, for the mountains."

"Oh, what a wonderful trip there is ahead of you. I wish I were a man and could go, and if papa wasn't so afraid of his heart I would go anyway."

"His sweetheart," remarked the dude, jokingly. The miss smiled and showed her pretty teeth-and all out there in the moonlight, too-and then the music began another one-step. Away danced the dude and his cheery companion, whom he told confidentially that he thought her father must be the most fortunate man to have such a good fellow with whom to travel. 
"I'd rather-you know, I'm in a terrible predicament, Mister Dude. Why, I'd rather dance with you than anybody in the world, yet I find you so interesting that I want to hear more of your trip, and you-come! Let us sit down. I know you must be very tired." And they found a comfortable seat.

"Tell me, did you ever see a real live bear?" she asked.

"Oh, yes, many a bear," and the dude winked at another dude across the room.

"Was it really alive!"

"Of course, the keeper fed it twice a day," answered the dude, smiling. And the pretty miss suggested that he must indeed be a wonderful dude.

"Say, Mister Dude," said she, again smiling, "do you know any bear stories?"

"I don't know any bear stories," said the dude, as he winked at another dude, motioning for the other dude to leave him to his fair companion, "but once a friend of mine was fishing out here in these very mountains. He had wandered off from the gang, and his guide, and was away from everybody and everything but the wild things of the forest. $\mathrm{He}$ was hiding behind a big rock between a mountain stream and another large boulder immediately behind him. Well, he was fishing and having right smart luck. Every time he would pull a fish out he would flip it over behind the big rock back of him; and, of course, he thought that he would climb over there presently and pick them all up. The fish kept on biting, and he kept on pulling them out and flipping them over the big rock, until he was very much surprised to find that his line was caught over there. He held fast to his fishing rod, reeling in some of the line; and, upon climbing over the big rock, his hair just naturally raised his hat from the top of his head; and there-well, what do you think he had? It was nothing short of a big fat bear. The fisherman raised his trusty weapon and-"

"The next dance will be another Virginia reel-every- 
body get their partners," shouted Mrs. Young. Everybody" did and on went the dance.

The crowd danced until they had their fill of dancing; and, like all other pleasant gatherings, had to disperse. The charming companions of the dudes were excusing themselves, saying good-night; and, oh, so sweetly. Isn't it wonderful how nice some people can make themselves when they are a long, long way from home, where there is no one to complain or criticize?

The hour had grown late. One of the dudes and Hurricane Bill had thought of their beds upon the ground at Libby Flats, and had hurried away; doubtless, they did not care for such a blaze of social splendor.

"Say, Floyd and Percy," said Bill, "I want a bed here for the night-wonder if they have any good ones." Floyd and Percy suggested that we might ask Mrs. Young. We did and were shown by her to a tent house where we found a pair of fine double beds.

How comforting it is to lie down at the end of a strenuous day in a good bed. Can you imagine anything better for these tired dudes? The air had grown cold and frosty. Our dancing had warmed us to a superheat. The heavy blankets as well as the bed were indeed appreciated.

"Bill, this is thoughtful of you-I thank you," said Percy as he blew the light out and jumped in bed. Floyd also thanked Bill, and Bill felt very well pleased over his bright idea, for were it not for such, we would have been lying on the ground on Libby Flats.

\section{CHAPTER VII.}

The cold gray dawn of the morning of August 28, 1917, came early to the dudes; and especially to dudes Floyd, Bill and Percy. Floyd had attended to that by yelling, "Powder River!" into the ears of the other two dudes while 
they lay snoring. "B-r-r-r!" they cried and shivered as they slipped into their hunting clothing, after a refreshing night's sleep. All of the dudes vowed that the thin air was as cold as real winter, and after much shivering and loud talking, the dudes awakened, among others, the proprietor of the establishment, paid their bills and hurried down to their camp.

The mountain side was frosty. We saw our camp in a distance. Ed was standing over the stove, and an odor of cooking java permeated the pure mountain air.

Shorty Kelly had rounded up the horses and mules, which had been grazing in the flats.

"What kind of cakes are these?" asked Percy, after the dudes had finished a bountiful breakfast of oatmeal, coffee, bread (hot biscuits), ham and eggs, fried potatoes, cakes.

"Sour dough," was Ed's reply.

"You know," interrupted Shorty, as he gobbled down three or four more cakes, "we always carry the sour dough in that black mule's ear."

"What a handy place," suggested one of the dudes, while the guides delighted in magnifying the fact, but the dudes ate through the whole argument and a dozen or so more cakes, and didn't care where the sour dough was carried.

As our guides and horse wrangler were packing for the road, the dancing partner of one of the dudes arrived to see us into the mountains, and I dare say, would have, had she not come at the precise moment that a certain ornery animal, named Pappoose, "spilled her pack," and then all of the guides and horse wrangler spilled a lot of mountain rhetoric. The dudine, as she was called by the natives, smiled and suggested something about the artistic temperament of the horse wrangler, paused long enough to have a picture taken, and then, to the music of a mountain canary, rode away.

"Harken unto the music of the mountain birdie!" shouted Shorty, as he tightened the ropes on a pack mule, and the dudes discovered the mountain songster to be noth- 


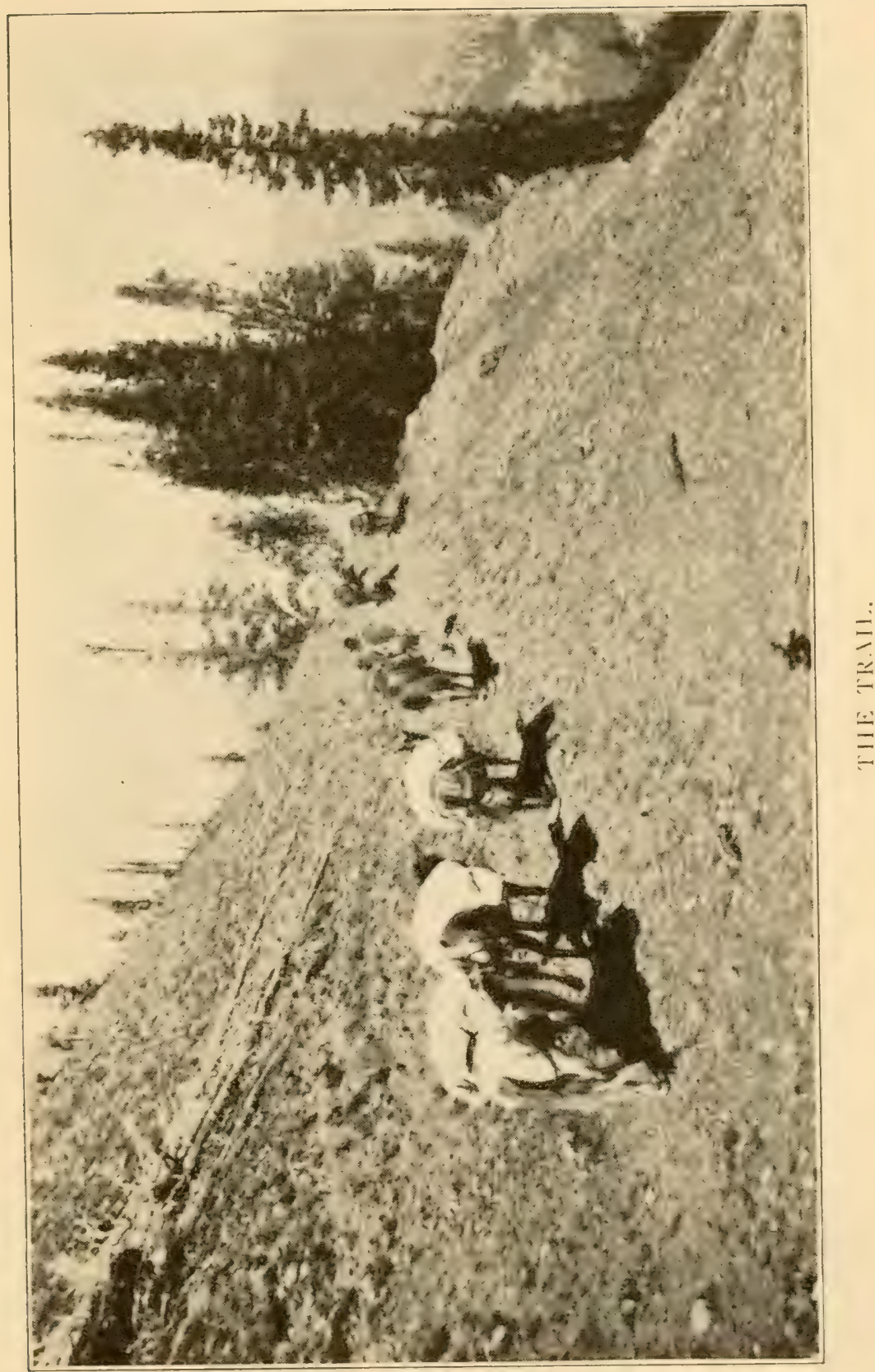


ing more than a mule, doubtless, giving the dude the general "hee-haw" for his success with the dudine.

By 9:30 breakfast was over, the mules and horses were all packed and the dudes were, with the greatest effort, on the backs of their horses, still headed for parts unknown.

We rode up the valley a few miles and then turned our pack into the mountains. We followed a trail, just wide enough for a horse to walk. Occasionally we had to push the horse over to one side to avoid being rubbed against a tree. We passed through a number of wooded parks which nature had especially constructed for the wild things of the forest.

On up we rode, riding at a steady climbing walk, up a winding trail into and through heavily wooded mountains, where, from time to time the chipmunks or squirrels would scurry over the trunks of fallen trees which had gone down in some storm. Some of them had fallen across the trail, and over these our horses would bound.

We rode around the sides of mountains, following a perilous trail. It often overlooked great precipices.

We followed the meanderings of Eagle Creek, winding and twisting our way through the mountains all day. Close upon the hour of five we arrived at what we were told to be Eagle Creek Meadows.

Now Eagle Creek Meadows lie between two mountains, a small but beautiful valley. The altitude here is higher, perhaps fifteen hundred to two thousand feet, which was the extent of our climb during our journey that day. The entrance to these meadows was closed by a heavy wood, and through this wood ran Eagle Creek and our trail. After passing through the wood our pack stopped and we dismounted. It was by far the hardest for some of the dudes. All of them, excepting possibly Joe, were very tired and sore.

The guides and cook busied themselves with camp. Our supplies and saddles were piled under a tree. Our beds were spread upon the ground. 
Our beds consisted of first a heavy tarpaulin, a pair of quilts, a number of blankets-enough to keep us warm-and then the tarpaulin was long enough so as to go under the bed and cover the top of it. In this way we had a place to sleep for the night. These beds in the morning were doubled and packed on the backs of our pack animals.

After this preparation for the night the dudes decided that they would go to the creek and take a plunge.

"Now, ain't that like a bunch of dudes," shouted Hardy, "always wanting to take a cold plunge. Well, I'll be d-d-you'll get a good cold one, all right. Just help yourself, the door to the bath is always open out here, but few go in."

The dudes, however, were not afraid of cold water and went merrily to the river with towels and soap. They pulled off their clothing and were about in the act of taking a dive when one of them cautioned the others as to the depth of the pool. Then the dudes stuck their toes in instead.

"In the name of all the holy Saints at once-whoopee! She's a cold bath," shouted one of the dudes, and his appreciation was echoed by all in voices loud and shivery.

"Why, the water is so cold, it just pains you,--doesn't even feel cold. Oh, br-r-r-r!" cricd another dude. Dude Floyd then pushed dude Percy in, and dude Joe jumped in to prevent being pulled in, while dude Bill sat on the bank mightily well pleased with having his clothing on.

"Aw, come on in, Bill-the water's fine," cried Joe, shivering, his teeth nearly chattering a tune. So Bill pulled off his clothes and slipped in gently, oh so gently, and dipped into the limpid water.

"Oh, how wonderful!" shouted Bill as he finished putting on his woolen clothing.

"I'm as fresh as a flower," echoed the voice of Floyd in the faraway hills, while Joe suggested that a little of 
"sech" went a long way. Bill vowed it was a man's bath, and the dudes, upon returning to camp and meeting the guides, were told by the guides that the idea was all right but the taking of the bath was worse to take than medicine.

The dudes were feeling so fresh that they suggested a walk through the woods, and the guides immediately acquiesced, our party, excepting our cook, who remained to get supper, went into the woods.

"That Shorty certainly is a 'bouncing boy', in the woods," shouted Floyd as he returned to camp, after having been out with Shorty. "Whew, it makes you blow and sweat," he said as he wiped his red face, and added that the altitude affected him very much.

"And me, too," shouted Percy. "I have run many a race, but never knew I could breathe like I did after taking a few rapid steps. My, it sets your heart a thumping." Joe suggested that Hurricane Bill was a regular mountain mule, while Hardy and $\mathrm{Hal}$ were likewise complimented. The dudes, however, were now content to sit down on the ground and have their supper of bacon and eggs dished out to them. We also had hot coffee, hot soup, hot biscuits and canned peaches.

After dinner dude Bill passed around a box of cigars with gold bands around them and some equally as fine cigarettes, while one of the dudes contented himself with a certain meerschum pipe.

"Shorty, have a cigar," urged Bill.

"No, Bill, I thank you, but I don't smoke," replied Shorty, grinning and blushing considerably as if he were actually ashamed of his virtue.

"Don't smoke?" answered Bill, quite astonished, "I'd hate to offer you a drink."

"Well," said Shorty, "it would be all the same."

"Don't smoke or chew, or drink?" shouted Bill, bewildered. "I'll be d-d, say, boy what do you do?" And Shorty blushed again and vowed that while he 
didn't have any of those habits suggested that he was a horse wrangler and could hold his own at "plain cussing." Bill said that he really believed that Shorty could from what he had heard from him while handling the pack train.

"Why all the virtue, Shorty?" inquired another dude.

"Oh, I don't know, it isn't any particular virtue-I just have found it won't work. I've had all of the bad habits, I suppose-from 'cussing' to drinking-but I've quit everything but 'cussing,' and a horse wrangler just naturally has to speak to a horse now and then, so a horse will understand, - that — of a Pappoose, you'd have a hell of a time getting him to hold a pack by saying dude words to him-now wouldn't you? Why, he'd kick a lung out of you."

"Say, boys, I'm mighty glad to hear tonight out here in the wilds this lesson of Shorty's. Bill has shown us that he is really virtuous, and solely for the reason that it is best to be that way-Shorty refrains from doing wrong because experience teaches him that he will be injured by his wrongful acts. I think a lot more good could be accomplished in the world by this way of urging a fellow to refrain from doing wrong, than because if he does not do right, he will not be 'as holy as thou art," "proclaimed one of the dudes, who looked very much like he was going to start an argument.

"Well," added another dude, "what difference does it make-let us go to bed. Come on! I'm going-why, I wouldn't start an argument here now for a feather bed; and God knows I could use just such a bed."

Ed had thrown a timely suggestion into our midst by snoring. He was just in the act of swallowing his tongue. Everybody was tired, so to bed we started, while Hardy ended the philosophizing with the statement that he didn't care why a fellow should do right, but that out there in Wyoming he had better, or he 
would get something knocked out of him, or shot in or out of him, if he didn't.

The dudes hunted up their beds. They had been somewhat carelessly cast upon the ground. The tarpaulins were all covered with frost, yet the dudes, little used to such roughness, pulled the covers back, their shoes off, and soon were fast asleep.

\section{CHAPTER VIII.}

Morning came shortly. The dudes were awakened by the declaration of immediate war upon an erring mule. Shorty Kelly had just finished rounding up the horses and mules. Ed had quit snoring long ago and was busy with breakfast.

"Now, Joe, I'll leave it to you if that isn't productive of a little mountain rhetoric," shouted Percy as he held before the two of them a frozen sock.

"Why, you big chump! don't you know enough to put your socks under your pillow," said Joe laughing, "and, besides, when you do that, you might not be bothered with the smell of the horse or mule which carried the bed during the day."

"Much obliged, Joe-being I have lost my sense of smell, and can't smell a mule anyhow, I'll put my socks, after this, under my feet." And Joe said that he guessed that would be all right, sug yesting that I was about the only one to please in the matter anyway.

The dudes stood around the cook stove, stretching, grunting and warming themselves.

"Here, you dudes had better hurry up, and get your breakfast. We cross the divide today," shouted Hardy.

The dudes hastened to wash. They found a skim of ice on the water bucket and after a fresh plunge into the river, or wash pan, as the dude desired, the dudes were busy at a sport dear to their hearts.

"Maybe you dudes had better sight your rifles," said 
Hal. As all the guides thought it best, we sat a box about fifty yards away and fired at a spot. We found each rifle perfectly sighted.

After the usual hustling, bustling and swearing, on the part of the guides and horse wrangler, our pack was made.

Our trail followed a wild mountain stream which was constantly growing smaller as we climbed and its waters rushed on by with a dull monotonous roar which ever seemed to caution us to beware.

About noon our trail became so steep that we had to dismount, walk, in a crawling climbing fashion, and lead our horses. Every now and then a mule would leave the line of pack. The horse wrangler or guide who was nearest the animal would burst forth into a blast of profanity; and the broncho or mule would generally, upon receiving the admonitions of the man of the west, slowly turn his head and jump back into the pack; yet sometimes, while they appeared to understand their noisy injunction, they had notions of their own. In a case like this the guide or horse wrangler would let out a few more withering blasts of mule language, spur his horse on in the direction of the disturbing element, and the intruder would soon be back in the trail.

The ascent was so steep and the abyss below so great that the dudes often turned their heads and looked toward the mountain rather than risk becoming dizzy from looking down; yet, occasionally, one of them would take a look into the depths, immediately over the trail, where had his horse slipped, oh so slightly, it would have been the great beyond for him. We rounded ledges, our horses walking on loose rocks, in places where it appeared to me no human foot could safely tread. The air was rapidly becoming so rare that we could go only a few steps until our hearts would beat and bound as if they would break. Every now and then we would have to stop for wind. We stopped any number of times. 
On one of these stops we ate our lunch, which consisted of a large biscuit and a piece of cheese. With this refreshment we climbed on. Our horses and pack animals appeared to realize that the trail could not last forever up. They wanted to go on and have it over with, and on we went.

We were now in a new and strange land of snow and ice. We found the air extremely cold and fresh, yet both man and beast sweat profusely.

"How long has this snow been up here?" asked one of the dudes, blowing heavily and pointing to a pocket in the north side of the mountain.

"God only knows," was the reply of the guide. "We had a lot of snow last winter-more than usual, but as to just how long that bank has been there-oh, well, it is like the mountains."

"Say, down there, Bill!" yelled Floyd, "don't you wish you were up this far?" And Bill wished he was up where Floyd was, although Floyd was only three or four horse lengths ahead, yet to gain the position of Floyd meant a struggle over the loose rock and around a boulder, which looked mightily as if it would come tumbling down and bury him forever.

We climbed on up the trail, or followed the head of the pack. The trail which we were following was only a small path, traceable in places. Into this path at various intervals ran game trails.

"These mountains are just as full of streets and thoroughfares of their own as a city is of streets and boulevards," remarked another dude, breathing heavily and sitting down to rest.

"Don't it make you a little nervous?" said a dude, pointing over the side of the mountain.

"Oh, not much," replied Joe, "yet I wouldn't want to slip," and just then a good sized rock rolled from its place and tumbled down and as Joe turned and winked the blood came to his cheeks. The stone rolled on down. 
we heard it on its way for a distance, and then saw it roll on down, but could not hear it.

"Well, sir," said Percy, after resting, "this horse of mine is as slow as death. He almost stumbled down on the automobile road a dozen times, but up here, he certainly does watch his step; and I'm mighty proud of the old gray after all, just take your time, old fellow, and bear in mind that this dude is in no hurry up here." And the gray mountain horse shook his head as if to say, fair enough, but keep on walking.

On we went. We climbed. We slid, caught hold of big rocks, and occasionally a small tree; and at times, we balanced ourselves between this world and the next.

"Hardy," shouted dude Bill, "do you ever lose a horse on one of these trips?"

"Yes, sometimes-" Hardy replied, and Hardy looked down towards Bill, and upon seeing Bill in a perilous position paused, and after Bill had climbed up to safety, Hardy yelled his reply.

"And sometimes a dude-" cried Hardy, laughing, as he climbed on as comfortably as one of the dudes would have walked down Broadway. The effect the altitude had upon the guides was not noticeable; and, especially, upon Hardy. He walked all of the way and stepped along merrily. Oh, my dear friends, shall we ever forget that rare specimen of manhood; his strength; his courage; his hardiness; his wholesomeness! His costume consisted of woolen socks; a pair of heavy shoes; overalls; a hickory shirt and a big cowboy hat. During all of the time I saw him in the mountains in the ice and snow I never saw him shiver. His body appeared as warm as his heart and he delighted in waiting upon what he called, "the tender plants."

We were all now wrestling with the most perilous climb taken by the pack train. We climbed on and up. Sometimes on all fours; sometimes clinging to a rock, which might have pulled out and fallen. All of the 
while Ed kept his place at the top of the line, leading a mule and riding-yet now he had dismounted, and the pack train followed him.

"Careful, boys," shouted Hardy, "the easier we handle the pack the better it is ; now everybody take their time."

Everything and everybody was deathly still. The dudes had quit talking, and the guides and horse wrangler had quit their swearing. I felt a little lonesome in this new land, and believed I could get along if the boys swore a little. In fact, I would have much rather have heard them swear than the heavy beating of my heart. I was glad to see the front end of the pack disappear over the divide.

Out there in Wyoming, on the top of the Rocky mountains, over the continental divide, rode the dudes. There was plenty of room on top although looking up there from a great distance it didn't appear to be.

We were now in the midst of the snowcapped mountains. Ice and snow were all about us. We had a magnificent view ahead and behind us-in fact, in every direction the scenery was wonderful, grand and immense. We looked down. There were the wooded slopes below, and the meadows; other mountains, a great panorama of natural wonders. Some of the mountains were swathed with clouds, while other white ships of the sky floated over the valleys and slopes, forming huge shadows below, which were constantly chasing themselves across the vast stretches. The wind was blowing up here. It was cold and icy. It seemed to be coming from somewhere, going somewhere, and on its way it cooled the hot cheeks of the dudes and helped dry the sweat which their journey up had brought forth.

Our hearts were beating rapidly. We were unaccustomed to life at such an altitude, possibly twelve to fourteen thousand feet.

We could have remained and enjoyed the many, many sights, yet the trail led on; ever on. We were now beginning to encounter the road down. 
The road down was mightily like the road up, only worse; and I can't say which I enjoyed most, the way up, or the way down, excepting that the road down made the heart beat less and was easier; yet the encouraging thought of ever going to the top was absent.

"Do we go down this ledge of rock with our horses?" shouted one of the dudes, as he stood bewildered and looked down, nearly losing his balance.

"Oh, yes, come on-you'll have a lot of thrills-why that's a boulevard compared to where you shall go when hunting. Come on, boy! Brace yourself, and watch your step," yelled Hardy.

The dudes did. They were sweating so that they had removed their hunting coats and leather jackets. They had tied them to their horses; and were now giving their hazard for what was in store for them.

Shortly after starting down the mountains, on the other side of the divide, we noticed a new mountain stream. It had bubbled out of a huge snowbank and was running down the mountain.

The trail which led down the mountain was practically the same as the one we had just come up on the other side. We followed the trail on down. We came upon some scrubby timber. We passed the scattering scrubby timber and rode into a forest of large spruce and pine trees. By this time the mountain stream had grown. It rushed along at a maddening pace, ever hurrying, like a great many people, to reach its level.

About 5 o'clock we made our camp on the north prong of Mountain Creek. This was indeed a beautiful place. We camped on the edge of a small mountain pocket, surrounded by high mountains.

The dudes were very tired, yet they were not as sore as they were at the end of their first day's ride. They had begun to be hardened. They slipped off of their horses with a considerable ease and pleasure. We unsaddled our horses and turned them loose to graze. 
We went to the river and washed our faces and hands. The water was icy. Nobody suggested that we should take a swim.

Dude Bill took out his fishing rod and some flies and walked the creek to fish.

We were now camping in the game preserve. While we all could have enjoyed camp meat, instead of ham and eggs, bacon, and food of that kind, still we felt that as we were in the preserve, the law should be obeyed. Our guns were not sealed. Possibly they should have been, but as it happened we left our camp at Libby Flats before the arrival of the forest ranger; and on this account we were not able to have them sealed. It was just as well-they were empty and were carried without being put together.

Ed busied himself with supper. In a little while his camp stove was puffing away in a normal condition. The smell of frying potatoes and cooking food filled the air.

Dude Bill returned to camp in time for supper. He was very tired, yet there was a smile on his face.

"I saw one of the most beautiful deer," cried Bill enthusiastically, as he helped himself to a bowl of soup.

"It was just around the bend of the creek. It was a beautiful deer-so very graceful. I watched it for quite a while. It was so pretty and innocent and seemed so unconcerned about everything-and yet it was constantly alert, perhaps watching for something, that actually-if I had had a gun, I don't think I could have possibly had the heart to have shot at it-my, it was a pretty thing."

"Of course, you would not," interrupted a dude. And then another dude suggested that it would have been against the law to have killed it anyway. "Well," added Bill, "it was a very pretty animal and I watched it until it went off carelessly into the timber."

"And you wouldn't have killed it had you had a gun?" asked Floyd, laughingly.

"I most certainly would not," Bill answered, looking rather angry to think Floyd would so question him. 
"Say, boys, sing!" demanded Floyd; and the dudes sang to that old familiar tune of Auld Lang Syne:

"It may be so, but we don't know,
It sounds so very queer-
We do not doubt your honest word,
But your ky-bosh don't go here.

AMEN!"

Of course, everybody joined in on the refrain and the mountains echoed and re-echoed with the grand amen.

"Anyhow, fellows, it was a beautiful animal," said Bill, "and the scene was immense."

"Here, Percy, have some more soup," shouted Ed. "If you don't step right in and help yourself, Percy, I am afraid that these roughnecks bane going to get ahead of you dudes." Percy laughed and suggested that he thought that he was able to take care of himself, even among these (pointing to the dudes and guides) roughnecks. He, however, accepted the additional bowl of soup.

"My," shouted Shorty, as he bit into a large, thick slice of ham, "I would certainly like to have some camp meat."

"So would I," shouted Hardy, "but just let me catch any of you 'roughnecks' or dudes with any," and Hardy looked rather serious and seemed to mean just what he had said.

"As to the dudes," vowed one of them, "I want to say that we have no intention, or desire, to kill any game in the preserve, or anywhere, before the law permits; and I don't think the guides have any other such notion."

We had a good dinner. Everybody was contented. We simply pulled away from the place where we were served on the ground to another place on the ground and made ourselves comfortable. Isn't it grand to be able to roll around on the ground and have no fear of soiling your clothing?

"Percy," whispered Joe, confidentially, "come along and let's get some boughs and we will have a fine bough bed tonight." 
"All right, Joe," said Percy quietly, adding that he thought that it would be wise not to make the bed on any pile of rock, or frozen manure, or logs or stumps.

"Come on, Percy, bring your pruning knife," cried Joe, going in the direction of some small spruce trees. The two dudes slipped away from the others quietly and went off to the edge of the creek with a tarpaulin. In a short time they had a large quantity of spruce boughs. We then got two logs and placed them together, leaving room for our bed to go in between them. We took the boughs and placed them with the butt ends toward the bottom and lying each one on top of the other, thus forming a mattress. We had about three inches of boughs under our bed. Of course we were not so particular about putting the boughs down under our feet, although, had we, we would have found our bed much better and warmer.

"There," said Joe, as he finished arranging the covers, "when we come in tonight we'll have a good bed."

IVe walked over toward the stove. On our way we found Floyd and Bill. They were dickering with Shorty. Shorty had stretched his bed underneath a tree and was blowing up a pneumatic mattress. With this pneumatic mattress Shorty had the best bed of anyone in the mountains. It was soft and comfortable. It was very easy to handle. It could be carried on the back of a mule very easily by letting the air out of it. And then, when you would arrive at the place where you would like to camp, the mattress could be inflated and everything would be ready for your bed. Shorty was just blowing it up. After he had blown it reasonably full of air, and some of the dudes had tried it, I think Shorty could have sold the mattress then and there for a fabulous cash price. Shorty smiled at the various offers. He said that he was afraid if he would sell it to one dude all the rest would feel slighted; and, rather, than incur any hard feeling he would dispose of the matter by keeping the bed for his own comfort.

(A pneumatic bed is a very important piece of equipment 
to have when traveling in the mountains. Had we but known of the many, many rock piles on which we were to sleep, I am sure we wauld have all purchased one of these mattresses, which could be bought at any sporting store for approximately twelve dollars; yet we didn't, so could not enjoy its comfort in the mountains.)

"Don't you dudes want to take a walk over to the big meadows? Perhaps we will see a herd of elk or deer," shouted Hardy. Of course, the dudes all wanted to go, so we walked across the creek, one of us falling in, wetting his feet and legs to his knees, and after a short walk through a dense wood of spruce and pine trees, came to a clearing. "Here is a dandy place-just keep still. Don't smoke, and we might get to see a big bull elk," whispered Hardy.

We laid down upon the ground and were very quiet. The air was cold and crisp, yet not too cold to be pleasant with hunting clothes on. The stars were just beginning to show their bright faces. Hardy told us that he thought perhaps we were too late to see any elk, yet as it was such a good place, we might see any number. We waited in this hiding, which we occupied at the edgc of the meadow, for a considerable length of time. We were disappointed in not seeing any elk or deer. Finally we got up and walked around in the meadows, and there we found any number of places where elk had bedded down the night before.

On reaching camp, Joe and Percy went around to their well-made bed and got into it. Floyd and Bill had to first find their beds and then, after finding them, find a suitable place to put their bed.

Did you ever lie down and sleep on the ground in the mountains away from everything, excepting the wild animals which live there? This our party did. And now that we reflect upon our venture, tell me, please, what wild animal prowled in our midst? We were away from civilization, away from the answer to a call for help. If we were to be protected, we had to do it ourselves. Our guns were unloaded-the law of our country demanded this. Did the 
framers of the law think more of the wild animals than they did of their citizens? Of course not. Yet he who goes into these places must take such risks. In our immediate vicinity were mountain lions, grizzly bear, black bear, bob cat, mountain coyotes and wolves. Had we but been able to see in the dark places in the nearby wood, we might have seen a huge grizzly stand erect on his hind feet, sniff the air-and maybe, for all we know, he might have walked in our midst and smelled of our beds. At any rate we were not harmed by any of the wild animals and slept peacefully until morning.

August Thirty,

1917.

\section{CHAPTER IX.}

We arose this morning at an early hour and found the usual skim of ice upon the water bucket. It was thicker than usual; and while we might have had colder weather, we believed that it was on account of the altitude. We had a heavy frost last night and our tarpaulins were covered with pure white.

"Joe, that was a wonderful bed," shouted Percy, as he put his feet into a pair of warm socks which had spent the night under his bed.

"Yes," answered Joe, "Can see the application of the old rule: 'how you make your bed, so you sleep." So Joe and Percy dressed. All we had to put on was our socks, trousers, shoes, our leather coats and hunting coats.

Oh, how wonderful it is to awaken in such a place. Our newly grown mustaches were filled with ice. IVe went to the mountain stream to wash: how invigorating! The water is cold, fresh and pure; and at times you may slip into the water, while standing on the rounded rocks and get your feet wet; and when you do, your feet appear wet to the bone with the icy water; yet in a little while they dry and 
you never remember of your wetting. It is so much different in the low country.

"Oh," ejaculated Floyd, who was just getting up, stretching the kinks out of his back and hips and grunting, "Bill, I think this is the rottenest bed we have had since we have been on the trip-why, it is right over a pile of rock." Bill got up and he too grunted and stretched himself and rubbed his back and then his gray whiskers, which were beginning to show, giving him the appearance of a veritable tramp, yet he was called "Dude Bill."

"Well, I'll be __, shouted Bill, as he looked to where dudes Percy and Joe had slept the night before. Joe suggested that there were plenty more of the boughs left on the trees, and that if Bill and Floyd would think about the matter the night before, they could enjoy a great deal of comfort.

We had breakfast that morning in the usual way. It consisted of oatmeal, ham, bacon and eggs and hot biscuits. We had visions of mountain trout when Bill had left with his fishing rod, yet Bill had seen a deer in the wild; and, of course, he having become so interested in the deer just naturally couldn't fish; so under the circumstances we forgave him and made the best of it with the ham, bacon and eggs.

Our provisions were again put upon the animals. We were soon jogging along on to what we expected to be our permanent camp.

We rode on through the mountains. We crossed the southern portion of the Yellowstone National Park. We had been in that portion of the park for some time. On our way we saw a big bull moose. The moose had been lying down out in a meadow. At first all we could see was his paddles. He finally got up and then we saw the full sized animal. He turned and looked at us, grazed and walked off into the timber.

The dudes and $\mathrm{Hal}$ rode ahead and took their fishing equipment with them. About noon we reached what looked to be a good place to fish. We fished for a few hours and 
caught a number of trout. Bill got so interested in catching a fish that he fell off of a bank of the river into the cold water. My, but it was cold. It didn't make much difference to him. He simply went on about his business and soon dried off. It would have been different in a lower country. yet here no one ever thinks of catching cold. Of course, too much exposure will cause a person to have pneumonia, and pneumonia in this altitude would be very severe indeed.

After catching all of the fish we could carry comfortably, we mounted our horses and galloped on to the trail. We followed it for some distance at a lively gait, and caught up with the pack train. We crossed the boundary line of the Yellowstone National Park. It was marked by the erection of a number of poles at intervals of possibly three or four hundred yards. We crossed what is known as Atlantic creek, rode on, and forded the Yellowstone River at a place where it was about one hundred feet wide. The water was running very rapidly and the dudes rode across with their feet over the pommels of their saddles in order to keep their feet out of the water. Upon reaching the other side we had to dismount, as the bank was so very steep, and near its base there was quicksand.

We were now in an open hunting country, although the law upon elk did not release our guns until the first of September. There were any number in this very vicinity. We needed camp meat, yet our desire to be real sportsmen and obey the law, prevented us from violating the game laws.

We rode on and joined the pack train. It was winding its way on toward a dense wood, following the meanderings of Atlantic Creek. We rode into the wood and stopped our pack train. It was late. We had to camp somewhere, and this, while it was the poorest place possible to camp, was our stopping place for the night. The guides and horse wrangler unpacked the tired stock, and turned them loose to graze.

Ed prepared supper and Hurricane Bill the mountain 
and rainbow trout, which the dudes had caught out of Yellowstone River. In a short time we had a good supper of fresh fish. The fish tasted very good. We were hungry and ate our share of everything.

This was indeed the worst place we had camped since we started on our trip. It was on the banks of Atlantic Creek. The creek ran by with its monotonous dull roar. The ground was boggy about camp.

We were very tired. Our guides built a campfire and the whole party sat around the fire. Hurricane Bill was sitting on his feet, warming his hands. Now Hurricane Bill has the reputation of having killed more big game than possibly any other man in the West; and, of course, with that reputation goes an innumerable throng of experiences.

"All right, Hurricane-now is the time to tell us how you roped that old grizzly bear," urged one of the dudes.

\section{THE ROPING OF THE SHE GRIZZLY.}

"Well, boys, it wasn't very much," began Hurricane Bill, as his dark brown eyes sparkled. "Well, I did rope a grizzly bear; and I expect you dudes, like a good many others, would like to hear me tell about it-" and then he took a puff at his pipe and looked into the fire, as if he were calling back memories of the past, and with another drag: "It was in the fall of '98-it was, myhow time does pass-now nearly twenty years ago. I was working for a cow company in Colorado. We were gathering up beef. We had gathered up all of the cattle in the pastures and were working in the gulches. It was in Wilson's gulch. We had been rather whooping it up-gathering up these cattle. I had just let out an extraordinary whoop, when something attracted my attention. 'There's a bear, boys,' says I. It was an old she grizzly bear; quite a large one. She was just taking her time, standing on her hind legs and appeared to be pretty well of the notion that she had about as much 
right there as any of the cow punchers. There were some trees and very little fallen timber. Well, none of us had a gun. We didn't have anything of that kind in our possession, so I says, 'here goes, boys, we'll rope the bitch.' She started up the side of a ridge, and as she topped the ridge I drew down on her with my rope. My horse wasn't a bit afraid of her and as she went over the ridge I caught her by the hind feet. Then this other fellow, my partner, he threw his rope. You know these grizzly bears have a great deal of 'savy.' Well, when he threw his rope, it struck all right but she caught it with her forepaw, one of them; and then the rope slipped down over her shoulder-she tried to hold onto it. The rope tightened-he rode up a bit, and I held up, and we stretched her out. We then had a bear; and you know sometimes when a fellow gets a grizzly, well, he does have a bear, there is a question of what to do-we had old sister grizzly on the end of our ropes.

"Of course, we had her all right-and we had roped a grizzly, and then came the question as to how to handle her after we had roped her. 'Well,' I says to my partner, 'say, you ride around that tree, and I'll draw my rope tighter and we'll keep her stretched out.' He kindy looked a little sheepish and said finally, 'all right.' $\mathrm{He}$ rode on around the tree, and then he tied his rope. All of the time I was sitting on my horse keeping her stretched out. Of course, my horse wasn't a bit afraid of the bear. It was just like roping a steer. My horse reared back upon his haunches, and held the rope taut so that the bear could not do a thing. After we had the bear in this position I pulled out my pocket knife, and I said, 'here,' to my partner, 'you take this knife and cut the bear's ham strings.' Well, he seemed to hesitate, he was a little bashful. I guess he had a right good reason to be a little bashful, because if that rope would have slipped and that old she bear gotten loose, under those circumstances, well, I expect she would have made it 
right interesting for two cowboys at that time. 'Well,' I says, 'here you take this pocket knife of mine and walk up and cut her ham strings.' Well, I remember particularly, that when I said ham strings, that boy's eyes certainly did open wide, and you could have knocked them off with a stick; or, 'you had better take this knife, or get on this horse, but if you get on this horse, the horse might move and that would cause the rope to loosen up, and in that way we might let her go, and something might happen to us.' Well, he braced himself and took the knife, walked up and cut her ham strings. Of course, during this operation the old bear let out some of the most terrifying howls I have ever heard in my life. When he had cut the ham strings we had her in tow, at our mercy - she couldn't do anything to us. We then hiked out and got a gun, and shot her. She had a right fine pelt."

"Say, Hurricane, didn't you feel a little skittish?" asked Percy.

"Well, now," answered Bill, "I don't know but that I did, but you know, that was when I was young - there was so much excitement, and everything. We did it so quickly that we hardly knew what we were doing."

"Bill, would you rope another grizzly bear, if you had a chance?" inquired another dude.

"Oh, I suppose so, yet I believe I would think a considerable about it. Of course, under the circumstances, it wasn't so bad, yet I can't help but think we were just a little bit foolish out there, not having any gun; still, there was a tree there handy-we tied the rope around it and stretched her out. Everything worked all right, but if something had have happened; or if the rope had have slipped, well, I guess there would have been two cowboys knocking on the pearly gates."

A stump was thrown on the camp fire. It was full of pitch. As it burned, it sputtered and the eyes of another cow puncher grew bright. 


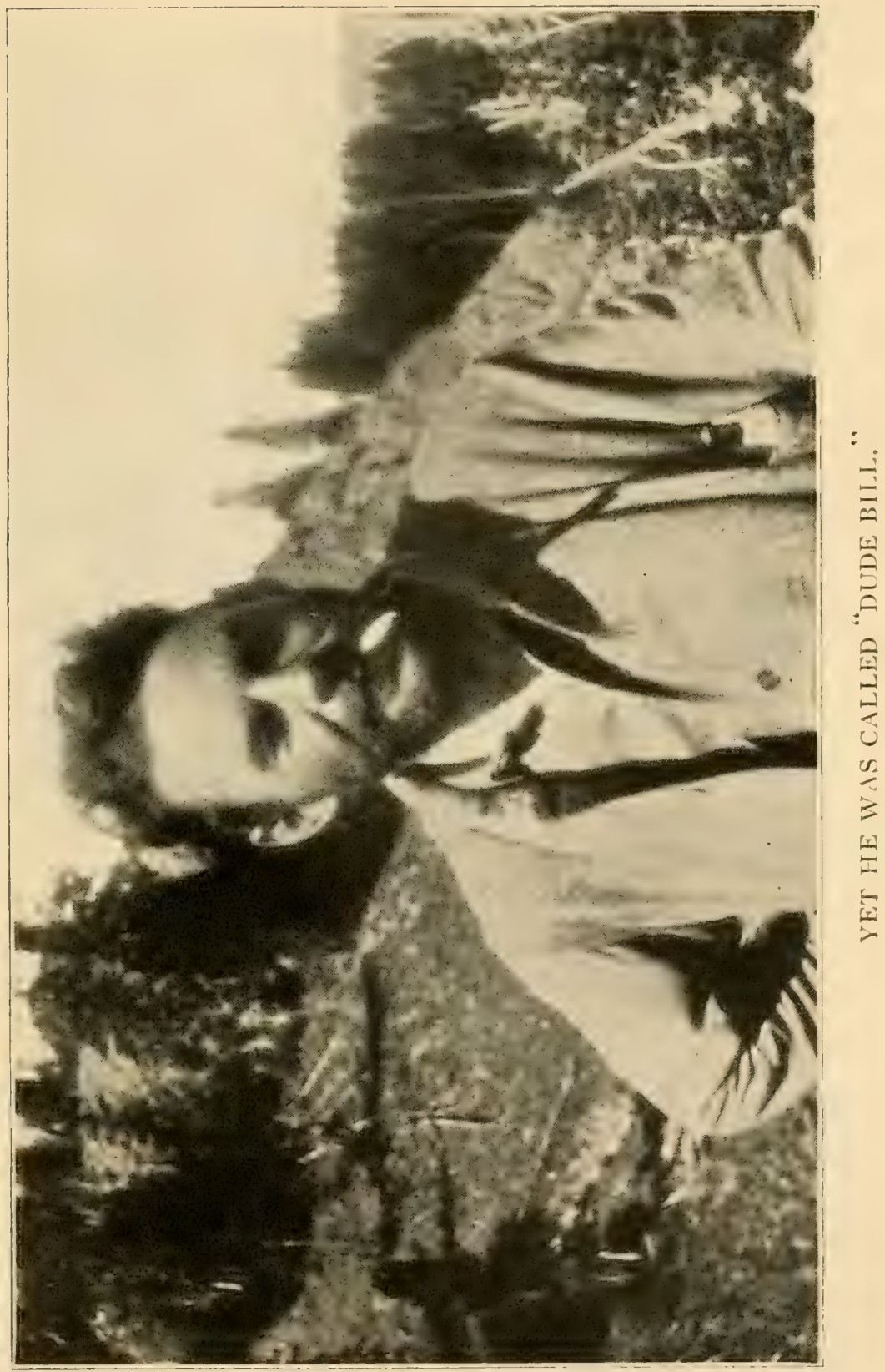



"Well," said Shorty Kelly, "I had a little fun once. I roped a big old gray wolf. My, but he let out a whoop when the rope struck him. Oh, how he bounced into the air! Whoopee! It was up and down. He was a big old wolf. In a little while I had him dashed to pieces. It was all over and there wasn't any trouble about it. He was just as mild as you please." And then Hurricane Bill added that he had had a lot of fun when he had roped a bob cat, and that the bob cat was jerked around in about the same fashion.

"How did you feel," asked one of the dudes of Shorty, "when you had a wolf on your rope?"

"Well, you wouldn't think much when you had a small animal like a wolf, or a bob cat-you know a horse is right strong and you can just jerk the eternal daylights out of anything like that-just let him bounce along on the ground a while and he will soon be peaceful and quiet; give him a few good stiff jerks, well, you will be safe enough all right."

"The best race I ever had," continued Shorty, "was when I roped an antelope. This one had one of its legs shot off, yet it was able to give me one of the merriest chases I have ever had. I finally got her roped all right, and tied down. It wasn't much after I roped her."

Hardy came with a large arm of wood. He threw it upon the fire. In a little while it was burning very brightly. The old pitch stump sent out a hissing spray.

"What's all the yelling and howling we hear over there in the mountains?" asked one of the dudes, evidencing some alarm.

"Oh, that's old Mr. and Mrs. Coyote, having a little party, I suppose. You will hear another bunch answering them presently," replied Shorty, smiling as he noticed the effect upon the dude.

We listened, and as the campfire flickered and the old stump sputtered, we heard the coyotes answer. Their answer was a fiendish blood-curdling challenge.

Shorty Kelly had been looking into the fire for some time. He had been whittling a stick. Doubtless the weird yells 
of the wild, to Shorty, like the songs of an old-time singer, brought back to him memories: the pure, sweet notes, the pretty faces of youth; the harsh and shrill yellings, scenes of tragedy.

"You come up with a good many strange things in the woods; and up here in this country, sometimes you have some thrilling experiences. One time when Ned Jones and I were up in the Park there was a mean old bear up there. He must have been shot, or something hurt him somewhere, for he certainly had a grudge against all the world and everybody. We were in camp. This mean old bear just came a-loping around where we were. He seemed to be in the notion of helping himself to somebody. As he came by Ned he threw a pillow at him, and after that Ned rolled up in the covers. Old Mr. Bear came right up to him. Ned says, 'He nabbed me; he nabbed me;' and old Mr. Bear bit him right through the thigh. He picked up the bed and ran off to the timber with it."

"Ugh," said Floyd, "he was a mean old bear."

"Oh, he wasn't the only mean one up here. Why once there were three freighters. They were camped at Turbid Lake. They had three wagons loaded with baled hay and vats. Two of the freighters slept on top of the wagons and one underneath. About midnight a big grizzly came into camp and grabbed the fellow under the wagon and started off with him. The two on top of the wagon yelled as loud as they could and threw sacks of oats and bales of hay on him, as he was dragging the fellow by the wagon. The bear let him go and the two men told him to come around to the wagon tongue and they would help him upon the load. $\mathrm{He}$ got to the wagon tongue, and each man took hold of his hands. They were lifting him up. The old bear made a run and grabbed him when he was nearly on top. The bear pulled him away from them and ripped him open with his claws, so that he died the next day some time."

"Why, didn't they shoot the bear?" asked Floyd.

"We were in the Park. You know we never shoot any 
bears in the Park. It is against the law," Shorty said as he spat into the fire.

"Well, I'll be d-, " interrupted Floyd. "I'll be darned if I'd be traveling around through the Park without a gun."

"Maybe you wouldn't, yet here you are right now in the midst of a bear country, in just such a position. If a mean old bear was to come up to you this minute, what could you do? Nothing. Just try to get away or stand up and let him box you up the side of the head; and you might slap back at him. Maybe you might, but if he hit you a good square one you'd never slap back at him or anything. I'll warrant that, they are so cussed strong." Floyd grunted, as if to say, "Well, I'll be," and Joe whispered to Percy something about as to where he had put his revolver. Percy informed Joe that it was some place in his war bag.

"All right," said Joe, "it can stay there as far as I am concerned. I haven't any time to fight a bear with a revolver tonight. I'm going to bed in a little while. I'll just naturally take my chances."

"Come on, Percy, and let us go to bed," shouted Joe after looking for a smoke, and failing to find it.

"All right, Joe, where's our bed?" Percy replied, as the two tired dudes went in search of a bed. They struck a number of matches and went moping around through the woods, looking for their bed. They found it and spread it upon what they thought to be the ground, got in between the blankets and went to sleep.

"Ed," said Floyd, after deciding that he had just as soon sit by the fire as to be cold and damp in bed, "did you ever get ahold of a cub bear?"

Ed rather smiled and proceeded to tell Floyd that he had been in a number of camps where they had had cubs.

"A cub bear. I just wish I could give every enemy I have, if I have any, a cub bear. Why they bane the meanest and orneriest animal that ever lived."

"Why? What's the matier with a cub bear?" asked Floyd. 
"Oh, nothing bane the matter," answered Ed, looking angry toward his friend, Floyd. "Oh, nothing bane the matter with 'em, yet everything bane the matter. Why, the little devils will yell and cry all night long, as you never can imagine. The most miserable night $I$ ever spent in camp was when they had a couple of cub grizzlies. They are the worst I ever saw in my life-if you dudes were to get any, I think, I bane 'yump my yob.'

Flayd laughed, and hoped Ed didn't have to "yump his yob"; yet he hoped we would catch a cub.

"What do you do here in the winter time," asked Floyd of Shorty.

"Oh, I generally trap-trap coyotes, fox, and anything of that kind. I make a very good living at it. It is a sort of 'holing up' for the winter, and then when spring comes we start out on our summer parties."

"What about trapping coyotes-how do you do that?" inquired Floyd.

"Well," said Shorty, "that's quite a mystery. You have to be right foxy to catch them; they are very smart. They will come and walk right around your trap, and step over it, yet they will not step into it, if they see it. You have to fix it so that they can't see it, and don't know where it isyou have to be right smart to do that, I'll tell you."

"That you do," interrupted Hal. "I have had quite an experience trapping coyotes, and believe me they are the most foxy animal that I have ever met up with. They are a great deal cleverer, I think, than the fox himself."

"Shorty, you were speaking about a mean old bear awhile ago ; did you ever have any of them ever bother you?"

"Yes, indeed. I dislike to admit it, but once I had an experience with a grizzly which r-a-t-h-e-r 'got my goat." " There was another mean old bear that came into our camp about midnight. He grabbed Ed Jones, the cook. When he grabbed Jones, I got out of bed, about eight feet away from him and yelled. We both yelled. I could not find anything to throw at the bear-and I'm right glad that I 
couldn't, for had I, it might have made him peeved, and he probably would have come for me in a minute and killed me. I picked up a 'tarp' and shook it at him and yelled as loud as I could. Finally he started to go away, but he went toward Ned Frost, and Ned hit him with a stick of wood over the nose, then he grabbed Jonesey. We were yelling as loud as we could, but as he (Jonesey) was in bed the bear was biting the bed clothes most of the time. As it was, the bear tore both of Jonesey's knees clear to the bone. I went over to my saddle and got my gun and as you know you are not allowed to have a gun loaded in the park-ivell, anyhow, under the circumstances, I loaded it, right or wrong, and started through the timber to get my horse that was picketed in a park quite a ways from camp. By that time the knees of Jonesey gave out and he could not walk, so he wanted the gun, in case the bear came back, as he was helpless. Well, I gave him the gun, and that was one time, boys, Shorty Kelly was scared. It was dark as pitch in the timber and I think I saw a big grizzly behind every tree. Yes, I'm a little ashamed to admit it, but I was just a bit scared, but I didn't have anything to protect myself with and that grizzly was about as big as any I ever saw."

"Shorty, what did you do with him?" asked Floyd. "Did he die?"

"Oh, no. We fixed him up the best we could and then took him up to the Lake Hotel and the Doctor took care of him."

"What's a matter; aren't you fellows ever going to bed?" shouted one of our party who had been kept away from the sweet land of dreams, what he thought to be, long enough.

The campfire burned low, and presently our camp party was fast asleep. 
August Thirty-first,

\section{CHAPTER X.}

We were awakened this morning in our carelessly laid beds by Hardy. He was chopping down a dead tree which he expected to use as stove wood. There was plenty of other wood lying on the ground, but he was so full of pep that he had to do something.

All of the dudes vowed that they had spent the worst night they had ever experienced, although I know none of them thought or dreamed of anything until morning.

We all went down to the creek and took a plunge. This plunge consisted of the dudes washing their faces and hands.

We had breakfast this morning in the usual manner, excepting we had rainbow trout. The rainbow trout tasted very good. It had been caught the evening before by the dudes.

In a very short time our horses were saddled, stock packed, and we were on our journey. This time we followed a prong of Atlantic Creek. Atlantic Creek winds its way through a great many mountains, in which were elk wallows, bogs, and all sorts of water growths.

"Isn't it queer, Joe," said Percy, as the two dudes rode along together, "to find all of this mud up here in the mountains?"

Joe thought it was, yet upon looking over toward the snow-capped mountains he could readily understand why all of the water.

As we rode on we passed two other camp outfits. We were informed that they were hunters and were anxiously awaiting the first day of September, when they expected to hunt bull elk.

We rode until about eleven o'clock. We passed through a great many clearings and forests. At this time we left all form of trail and rode into the mountains, which were very rough and wild indeed. We followed our guides. They led 
us on through the forest, around the mountain sides, through many more beautiful parks, the formation of which may be of interest. These parks are generally upon the slope of a large mountain. During some of the winters past this slope and another steep slope immediately above have become so filled with ice and snow that the weight of the snow and ice caused itself, when the thaw came, to slip off and come dashing down the mountain. These ice slides, or small avalanches, when they come dashing down, take with them everything in their path; whole forests are cut off and wiped out, they being carried on down the slope. After nature has performed this job of clearing, the country is leveled of $f$ by the winds and rains, and the grass seed takes root and grows; and here we have a park especially created for the creatures of the wild.

"This certainly is an elk country," said one of the dudes to a guide. He was informed by the guide that it was one of the best places in the world for them; practically, the best place in the world at the right time of the year.

"There is plenty of grass here, and then the altitude is high enough to be cool," said one of the guides, "and there are not many flies. Yet I see a number of these, what we call 'no-see-'em flies.' They might drive the elk higher up' into the mountains-perhaps, up there," pointing, "around those rimrock. They will come down here tonight, possibly, and that's when they bed down, after they get through grazing," added Shorty.

We continued our journey on through the deer and elk parks, climbing to a higher altitude, always following a mountain stream, until we reached a high pocketed valley, about snow line, where we decided to pitch our permanent camp. Here we dismounted and unpacked. We erected a cook tent, a dude sleeping tent, and three teepees for the guides. We found, where we had decided to camp, a number of dead trees. We cut these trees down so that in case of a storm they would not blow over on our tents. While we were arranging our camp we looked over on a mountain 
side across the creek, a few hundred yards, and there saw a bull elk. The elk stood in an opening a short time and looked at us curiously. He satisfied his curiosity and bounded into a patch of trees.

All of the dudes were tired of travel. We had been traveling steadily since the 24th day of August. We were now at our permanent camp and in the midst of the hunting country. Our guns were not sealed, yet it was the thirtyfirst day of August and the law of the state of Wyoming did not permit us to hunt elk until the first day of September. We spent the afternoon about camp, getting our rifles ready, oiling and cleaning them and preparing and assorting our ammunition, so that we would be ready to go for a hunt early the following morning.

"Now, doesn't that call for profanity?" shouted Percy, after he discovered that the clerk at the shoe store had put in the wrong size pair of shoes which he had especially purchased for mountain climbing. "Why, they are an inch and a half too short," added Percy, very much vexed.

"Percy," said Ed, pacifyingly, "that certainly bane too bad-you can use my overshoes. They will keep your feet warm." And Percy thanked Ed, who, having looked very much as if he could wear the shoes which would not fit Percy, was presented with a pair of heavy mountain shoes.

The guides then drove some hobnails into the shoes of the other dudes, and prepared them for a climb in the mountains.

"We'll have to be as quiet as we can, boys," said Hardy. "Let us not disturb the elk if possible, and tomorrow we shall hunt."

"Have you heard any of them bugle, Ed?" asked Shorty. Of course the dudes all wanted to know about the elk bugling. Shorty told us that this was the time for them to bugle; that elk had times for everything; a time when they bugled; a time when they grazed, and a time when they bedded down; and that if we were to catch any particularly big elk, we would have to always study the nature of the 


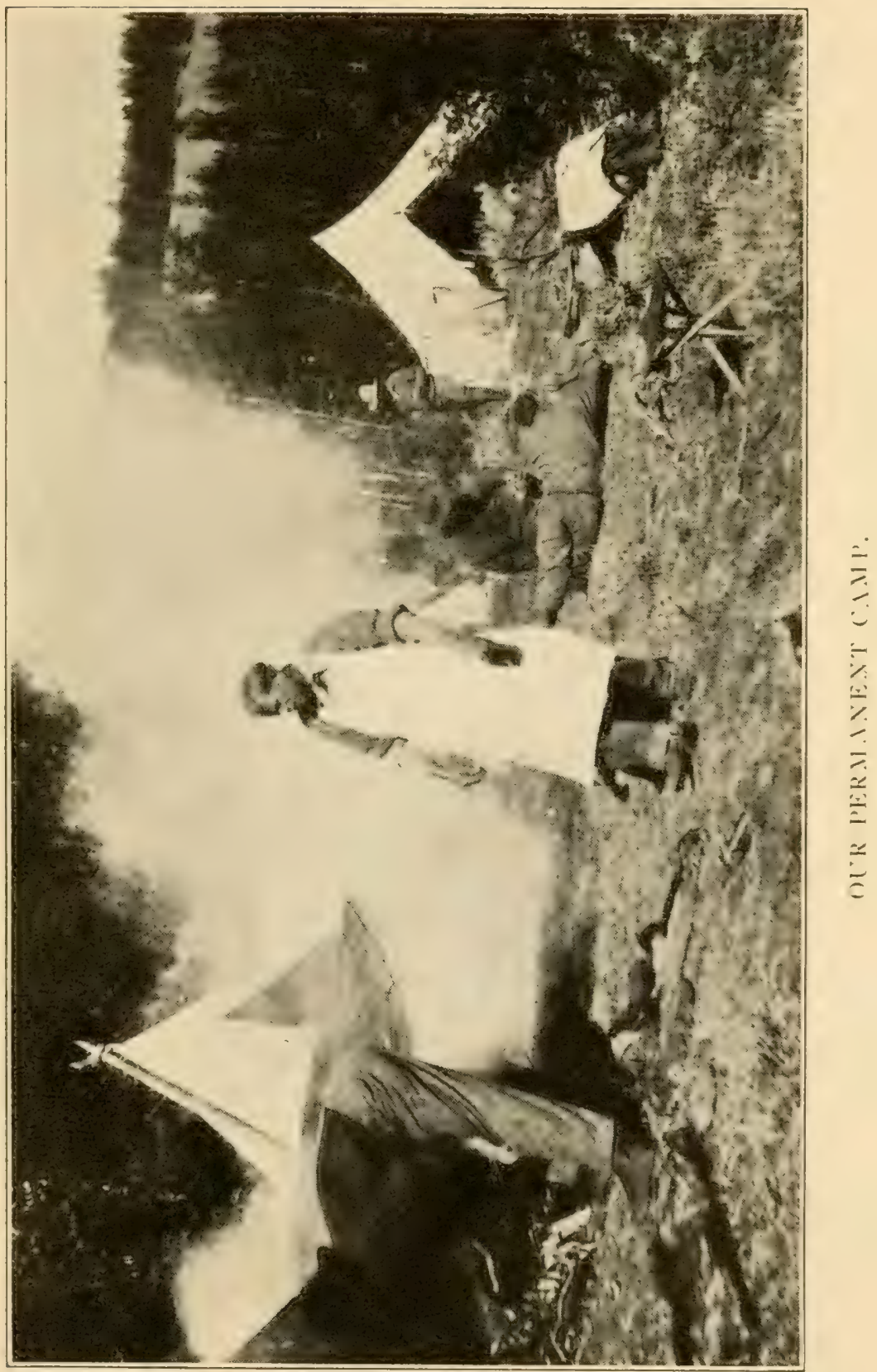


animal, and learn his ways and that then we might find them.

"Why, hunting is just as much of a science as anything else. You have to know animal life; have to know what they enjoy, what they do, in order to know where to find them-and that's just what we guides do out here in the mountains. We will show you elk of all sorts, and if you can shoot a gun you will undoubtedly get some very good prizes, for they are in this country," said one of the guides.

Shorty had a two-fifty Savage rifle. He had cleaned and oiled it thoroughly. Hardy, a Newton; Hal and Hurricane Bill, Winchesters; Joe, a thirty-thirty Winchester; Floyd and dude Bill, thirty-five Remingtons; Percy, a thirty-five Winchester automatic.

"What kind of a gun's that, Percy?" cried Shorty, as he looked at a pretty little rifle with which Bill had presented Percy.

"Why, that is a thirty-five Winchester, automatic," said Percy, examining it. "I don't like the looks of the size of the shell. It appears to me that there is too much lead for the powder. It looks to be a wonderfully quick operating gun, but I believe it is too small, don't have powder enough."

"Why, at two hundred and fifty yards, with that gun, Percy, I'd just as soon try to kill an elk instantly by spitting at him. You can't have any luck with that-the bullet is too heavy for the powder," said Shorty earnestly.

"Now, isn't that a bit of lu . k-my shoes won't fit, and my rifle is too small. Oh, well, such is life. Yet, I'm inclined to think that my luck will change, and I shall have to be very particular, and if I do, perhaps, I shall bag the biggest and best trophy. That's the way luck generally runs. Shorty, do you think I had better take it in the mountains with me?"

"Oh, yes, you had better take it along with you. You will have shots with it. If you can shoot straight, why, of course it will bring down some big game if you hit it in a fatal place. If we see any fine prizes, I'll let you have my gun, but it's too bad you have that little old gun with you. 
Didn't Hal tell you in his letter what guns to bring with you?" And Percy informed Shorty that Bill had told him that Bill knew just what to get-didn't want Percy to have to bother with the matter; and to avoid making a mistake he had purchased the guns, and yet, through a mistake, had bought a thirty-five Winchester automatic, thinking it the same as the thirty-five Remington automatic.

"Of all the guns, the Newton is the best," said Shorty. "Of course, you can kill most anything with that little gun, but I wouldn't want to have to try to kill a bear with it; yet you could kill a bear with it, if you were to hit it in the backbone, cut the spinal cord. That is about the most effective place to strike a bear. If you run onto one you had better take a good deal of pains, if you shoot at him at all. Yet just cut the spinal cord and you will be safe."

Dude Percy looked rather downcast, yet, he having shot a rifle in years past with a considerable niceness, took heart. He was glad to hear what Shorty had to say and, in a perilous moment to come, it served him very well indeed. It is wonderful how much valuable information a person can pick up if he just listens to those who know more about things than he does.

"How do you know where to find these elk?" inquired Percy of Shorty.

"Oh, why I know where to find them all right. That's my business. You'll find them right up there on that mountain over there, right close to timber line, in the edge of it, just out of the way so 'no-see-em' flies will not bother them; where it is cool and the air is fresh. You are bound to find them up there. We'll go up there tomorrow and we will more than likely find a whole herd of them, and if you will watch very closely you will see how they operate. You will find that a herd of elk always guard themselves by having out sentinels. There is always an old cow, at each end of the herd, when they are grazing, on duty; and then a cow on each side. Now, whenever these cows hear anything out of the ordinary they give the alarm and that turns the 
whole herd in search of safety. These old cow elk are very wise. They watch; they watch for grizzly bear, mountain lion, or anything which might harm them, and hunters. They can smell you. When you see an old cow stick her nose up in the air and sniff, then the elk, if they can get your wind, will be going from you. They can also see well. You want to be very careful not to let them wind you. Get your wind as we put it-for if they do, you can't get a shot at them very easily."

"Where do you say the bulls stay?" asked Percy.

Shorty told him that they generally stayed off by themselves, unless it was the time when they were running with the cows, and that at this particular time they would gather up as many cows as they could carry in their herd and would go along with them.

"About that time, you will hear the elk begin to bugle," added Shorty, as he picked up an ax and began chopping a tree down for stove wood.

"What's bugling?" inquired dude Bill, who was standing around listening.

"Why that's their challenge. The old bull elk on one side of the mountain will bugle out his note of challenge to another bull, on the other mountain. It is their way of proclaiming that they are king of all they survey. These big bulls have deep bass voices. The little bulls have high voices; we call them squealers. If you hear a squealer, why you can generally always tell that he is not much over a five-pointer, but if you hear a big deep bass bugle, that seems to come from way down deep on the inside of the animal, why, that's a big bull, a big six-pointer."

We spent the afternoon in this way, and, after having about the usual supper, walked into the mountains. We found a great many tracks of elk and bear, a number of fresh tracks. From these tracks it seemed as though the woods were simply full of elk. We didn't see any at this time.

We were given our first instructions as to how our guides 
wanted us to conduct ourselves in the mountains while hunting. We were told that we were not to smoke, or use tobacco in any way, for the reason that the wild things in the mountain would smell the tobacco smoke a great deal quicker than they would the ordinary human being. We were told that we were to walk along, and keep close to our guides, and keep quiet and not to talk, because the wild things of the mountains could hear as well as smell, and not to shoot at anything until the guide told us to shoot. We were cautioned about shooting at the first elk that we would see, as it might be a chance to get a small one and let a big bull get away.

We made some permanent beds for the dudes, and filled them well with boughs. We had reasonably good places to sleep, yet, while a bough bed sounds all right, I must confess I prefer any of the worst kind of mattress beds to them. They are softer than a rock pile, yet are hard enough after a day's tramp in the mountains.

The dudes and guides played a few games of pitch after returning from our walk, yet the pitch game, while it was played with much care and study, and a considerable swearing-by, of course, the guides and horse wranglers--grew monotonous and we went to bed to dream of the big game we were to kill the following morning.

September First,

1917.

\section{CHAPTER XI.}

Prompted by our keen desire to go hunting, we awakened this morning very early, long before the sun had shown its face aver the mountain tops. We were given, after eating breakfast, a large biscuit and a hunk of cheese. Each dude and his guide went into the mountains in search of a prize elk.

The morning was cool and fresh. We had had a frost 
the night before and the ground was white. Shorty and dude Percy walked up the creek which ran by our camp site. We walked for five or six miles up and into the mountains, until the creek grew very small. As we proceeded up the mountains the heart of Percy beat very rapidly, and the altitude affected him so that he could take only a few steps without having to stop and rest.

"Come on! We'll take this game trail here and follow it on up," cried Shorty, "and find out what it leads to."

The ground was literally covered with elk tracks. It seemed as if a great herd had just passed ahead of us. The tracks were fresh. We followed these tracks on up the creek. They led into the timber, and then back into the game trail and back across the creek, and then again into the forest. Upon finding that the tracks led into the woods Shorty told me that it was useless for us to go any farther. as we would be unable to find any of the elk in the mountains at this particular time of the day. He thought that we might happen to run onto some, yet it would be best for us to go back to camp for lunch and wait there until three or four o'clock, and then start on another hike. We did this and returned very footsore.

Up to date we had been served bacon and eggs, ham and eggs, and then bacon and eggs and ham and eggs. It was getting very tiresome. Dude Percy was beginning to feel a little uneasy as to the matter of supplying the camp with meat. "What if none of us are successful in bagging any big game?" thought he, with visions of feasting three timcs a day on bacon and ham.

"Cheer up, Percy-tomorrow you will have plenty of fresh elk tenderloin. We shall have all of the meat you can possibly eat, and a lot more," said Shorty encouragingly.

On by one the dudes and their guides returned to camp. They, too, had seen a great many tracks, but had not had a shot at an elk, nor had they seen any elk. They were very tired. We were served supper in the cook-tent.

During our absence Ed had made a table out of pine 
poles, which he had cut from poles about three inches thick, cutting them in two in the middle and then flattening the ends so that they would lie level on a cross-piece, being in such shape that the top of the table would be supported by cross-bars or poles laid into notches he had cut into four additional poles he had cut for table legs. Over this Ed had spread an oil cloth, and on this table we dined in style.

Dude Bill started a game of pitch. Everybody joined in the game. It was exciting for a while, yet very soon the dudes being tired, it grew monotonous, and everybody went to bed.

September Second,

1917.

\section{CHAPTER XII.}

This morning the dudes slept late. Their keenest desire for hunting had been worn off by their long tramp in the mountains the day before; yet, in due time, they were up and went again into the mountains.

Shorty and Percy had walked and climbed all morning. They had seen evidences of bear, coyate, deer and elk; and tracks of the last two mentioned animals, yet they had not seen any elk.

"Well," said Shorty, after stopping for Percy to rest and get his wind, "I suppose we had better go on back to camp. It looks as if we will not get any elk for several hours-they have gone into the timber again. We had just as well go back to camp for lunch."

Percy was feeling very tired. His feet were wet. His shoulders were aching from carrying his rifle. He had carried it first upon one shoulder and then upon the other, until now he believed he had a boil upon each.

Shorty and his dude walked along slowly back down the mountain side and in the course of an hour or so they reached camp. Everything was quiet and gloomy. Ed was 
busy cooking. He inquired if we had any meat. While we were informing him Hurricane Bill and Joe came in and told us of their experience in seeing tracks, yet no game. Bill and Hal came trudging in. They, too, had seen a great many traces of game but had not seen anything worth while. The dudes were all very tired and rather dejected. They laid down upon the ground and rested.

"Well, you dudes had better sit up to your dinner," shouted Ed. "It bane getting cold very shartly."

The dudes complied with the request of Ed, and were served a very good dinner of hot soup, hot corn, hot bread, black coffee, and the usual meat-ham and eggs.

"Oh, h-_!' cried one of the dudes. "The same yesterday, today-shall I say forever: ham and eggs?" Shorty and all of the guides vowed positively that we should not, yet the dudes were beginning to feel quite dubious.

"Say, you dudes," shouted Percy, as he struck a match to his pipe, "our meat is beginning to run pretty low, and, while we dude hunters do not need any stimulant, yet I want to make a suggestion. I want to offer a prize for the first dude who kills a five-point elk, or better. Say we make it fifty dollars. Say that each one of the dudes turn into a general pot fifty dollars, for the dude who is successful enough to bring in the first five-point or better bull elk. Do I make myself plain?"

All of the dudes thought that dude Percy had made himself exceedingly plain, and, of course, as all of them expected to win the prize, very cheerfully offered to pay their portion of it.

"Hardy, did you hear that?" shouted Floyd to Hardy, as he proceeded to drink another cup of coffee.

"I surely did, and I think, Floyd, you had just as well begin to figure on what you are going to buy with that money, for I am going to take you out where you will have a good shot at a bull elk right away."

"Say, Hal! Where's Hal?" shouted Bill. And Hal showed his head around the corner of the tent and asked 
what was wanted. Dude Bill informed him of the prize and told him that he would fifty-fifty with Hal. Of course, then all of the dudes offered to do the same thing.

It was agreed that the time should be taken of the exact moment each dude killed his elk by the guide and that the first dude to bag a five-pointer or better should receive the prize.

All of the dudes were filled with the keenest of anticipation. Joe and Floyd said something about the best fivepointer or better which a dude would want to have mounted and take home with them. Dude Percy said that he thought that as the possibilities would be that he would not get to kill but one he was going to take home the first bull he killed; however, as each dude was going to kill the first fivepointer or better, as soon as lie got into the mountains, no further disposition was made of the prize. The dudes very quickly disappeared from camp. They all went in different directions, into the various mountains.

Shorty and Percy had decided to go back up the mountain stream, which flowed by our camp. Floyd and Hardy had decided to go up that stream a few miles and then to take a game trail off to the right, crossing the stream and going up into another mountain, and there they expected to find their bull. In order to do this Floyd, Hardy, Shorty and Percy all walked along together up the stream. It was a gradual climb. In places the road was muddy and snowy; in other places we climbed over loose rock, around boulders, and then through some fallen timber. We were walking up a game trail and approaching an opening, a small game park high on the mountain side. Floyd and Hardy were in the lead. I looked immediately ahead and saw Hardy nudge Floyd, and point. Upon looking in the direction in which Hardy was pointing, we saw a beautiful bull elk standing. His right side was facing us. "Go ahead and shoot, Floyd," whispered Percy. Floyd cocked his gun and raised it. $\mathrm{He}$ took aim-fired! He fired again, and again. Percy raised his rifle and fired. The elk bounded into a timber patch, 
and yet acted as if he had been hit. He went on toward the top of the mountain.

"Come on, Floyd, let's go up into the mountain and get that bull," whispered Percy, as he put in another load in his rifle. Percy and Shorty ran on up to where they thought the elk had gone. We went over loose rock, up, in a very high altitude. It was fast telling upon the heart of Percy. He had to stop to rest. Floyd did not seem to hea: Percy, or at any rate went in another direction. Percy and Shorty ran on after resting. After climbing a few hundred yards, which seemed to Percy a very long, long way, they came into another opening, or clearing, and upon looking up and over a number of rocks, possibly a hundred and fifty yards away, they saw the bull elk. He was standing there looking a little dazed.

Have you ever hunted all day for something, and then, upon finding it, become so excited that you could not shoot it? Well, now, this was the case with Percy. He had climbed high in the mountains on his quest. He had found it. He had a most excellent opportunity to bag a large bull, yet he was breathing heavily. He was nervous and excited. He raised his gun. It weaved from one side to the other. He fired!

"You didn't even hit the mountain," whispered Shorty, disgustedly. "Try it again, old boy-now calm yourself." Percy fired again, and this time, while his ball hit the mountain, it did not hit the bull elk, and then Shorty gave Percy a friendly "cussing," and Percy said something about his gun, and borrowed Shorty's rifle.

"All right, take my gun. You can't blame it on that gun, if you don't hit it," Shorty said, laughing, as he handed Percy his gun. Percy took the rifle, which he had never shot before. He was breathing heavily; still nervous and excited. If there ever was a young man in the world who had the "buckaggie," Percy had it and the worst kind; and the sad part of it was that he was beginning to realize that he could not control himself under the emergency. Notwith- 
standing this, he raised the rifle which Shorty had let him have. It wavered, yet not so much. He took aim-fired. This time there was a splash in the mountain side immeciiately below the heart line of the bull. The bull then bounded, made a couple of jumps. Percy fired again. This time it was with greater caution. The elk collapsed and rolled down the mountain side.

"That's the time you got him. Don't shoot again, Percy ---he's as dead as he will be a thousand years from now," shouted Shorty, smiling. "By thunder, you can shoot a gun -but of all the "buckaggie!" " And then Shorty laughed until he was nearly out of breath and stood on first one short leg and then the other. While Shorty was laughing Percy gained his wind, and the two started for the place high in the mountain where the elk had fallen. The path Shorty and Percy took led over a number of large boulders, and loose rock, around several yawning gulches. Percy could only go a few yards and then he would have to stop. Shorty went on. While Percy was getting his breath, resting, looking up the side of the mountain, he saw that Shorty had already reached his prize and was rolling it down the mountain side. The bull had just rolled up against a large rock and lodged. Percy climbed on up to where the elk lay.

There before Shorty and his dude lay a magnificent animal. It was as big as an ordinary mule. It was fat, and had every evidence of having just previously enjoyed good health. There was a little trickle of blood coming from the neck, while quite a current of blood flowed from a place behind the left leg, immediately in front of the heart. There was a hole there about as large as a lead pencil would fill.

"Come, Percy, give me a lift," shouted Shorty, and the two took hold of the hind legs of the bull and turned him around, pulled him out from behind the rock and rolled him on further down where he lodged behind another boulder.

The excitement of this dude over his conquest ran high. He was careless with his step. He had taken off his leather 
coat and hunting coat. He had tied them around his hips, tying the arms of each in a hard knot, around and in front of him. He then hurried on down to the bull. On his way he slipped and rolled and was stopped at the edge of a ten or fifteen-foot drop by his coat catching on the end of an old tree. He recovered and walked on carefully.

Floyd and Hardy came to the scene.

"It's a five-pointer, all right. There! One, two, three, four, five-it has five points," said Hardy. "It's not a very cood one, but it has five points all right on each side."

"I wish to congratulate you, Percy," said Floyd, "but I am anxious to know if any of my bullets are to be found in the elk."

"All right, Floyd; we'll just look and see."

In the meantime Shorty had taken out his hunting knife, and had cut into the animal for the purpose of bleeding it.

The two dudes then examined the elk carefully. They found a hunk of lead in the neck, and upon picking it out it appeared to be the bullet of a thirty-five Winchester automatic.

"That's your first bullet, Percy," said Floyd, as he handed him the bullet. "Keep it as a souvenir; the first bullet you have ever shot into a bull elk."

"I can readily understand how I happened to hit the bull in the neck. You know my gun is very hard on the trigger, and I pulled it off to the right, the first time I shot at the bull."

Shorty and his dude then rolled up their sleeves, above thieir elbows. Hardy and Floyd left in search of another bull.

"There, Percy; hold those front feet apart," said Shorty, as he started an incision down its front. Percy took hold of the front feet and held them apart. The two of them then cleaned the elk, and propped it open, and left it in the mountains to cool.

They took out the liver of the bull, so that we would have some fresh meat at camp. They also took out the heart, and 
through the center of this heart they found a rifle hole large enough to put three fingers in. The two-fifty Savage bullet had gone through the heart and then it appeared to have exploded on the other side. It was the notion of Shorty that the elk had met instant death.

By this time the shadows had crept down the slopes of the mountain range which lay between Shorty and his dude and their camp. Behind these huge mountainous banks of green, and peaks of desolation, the sun was rapidly sinking, sending flaming banners across the sky. It had begun to grow dark. Percy carried the rifles and Shorty carried the liver of the elk, which, possibly, weighed fifteen or twenty pounds. They walked on back towards camp.

"Come on, Percy. You won't have much time to stop and blow," cried Shorty to his weary dude. "We must hurry, or we will be in danger of being caught in the dark. It will be dangerous for us to be here then-you are liable to stick your eye out any minute or fall, so come on!"

Percy picked up the guns and hung them over his sore shoulders, and started on. They walked, and slid, and walked some more, for a mile or so. They came to a clearing and sat down and rested. While resting they heard a six-point bull elk bugle. It bugled a number of times.

"Do you hear that challenge?" said Shorty. "Now, let us not say a thing about this and tomorrow morning we'll slip up and get that bull. He must be a dandy specimen."

"All right," whispered Percy.

Oh, how tired he was! How his shoulders ached! He thought the rifles would surely crush him.

They walked on until they reached a deer park and there they sat a while and watched something, which turned out to be a large white rock. They thought it was another bull elk, as they always look white against a dark background. They got up and walked on. Oh, how his back and shoulders did ache, yet he was very happy. He had been successful. He had obtained a prize and camp meat; and then he was very proud to think he had killed the first bull elk on the hunting 
trip. Of course, he didn't know that it was the first one, although he felt it must be. His luck had surely changed. "Powder River!" shouted Joe. "Show blood, Percy, if you want us to believe your story," greeted Percy and Shorty as they came into camp and presented themselves for inspection. Notwithstanding the fact that Percy and Shorty had stopped at the mountain stream and had endeavored to wash the blood from their hands and arms, they looked as if they had been in one of the most villainous murders. They were bloodstained from head to foot. So they went down to the mountain stream and washed with soap and cold water.

Upon our return to camp we were served with hot soup, coffee, ham, biscuits, hot corn and tomatoes, and then we had some raspberry jam for our hot biscuits. It was indeed a pleasure to see Shorty eat jam and biscuits. My, my, what a capacity that boy had for jam and biscuits! How he did enjoy a large hat biscuit, covered with butter and jam! He stopped his biscuits and jam, and cut off a few slices of fresh liver. He fried them. It tasted very good as a change. Of course, all of the dudes had a taste.

"Well, Percy," shouted dude Bill, "tell us all about it." Of course, Percy had to tell again how the elk had been killed, and when Percy had finished telling how he had been seized with a fit of "buckaggie" and could not, for a moment, control himself, to the extent of hitting the mountain, he was amused to hear the dudes sing that grand old tune:

"It may be so, but we don't know

It sounds so very queer.

We do not doubt your honest word,

Yet, your kybosh don't go here.

\section{AMEN !"}

"Yet he shot him right through the heart," shouted Floyd, laughing. "I suppose you did it on purpose? Just naturally picked out the heart and then put a keyhole in it." And Percy vowed that that was just the thing he had done. 
"Ready, boys, sing," shouted Floyd, as he led, in a sonorous voice, the above song.

"Well," said Percy, "that's the story of how it happened; but what did you dudes do?"

Joe had been sitting quietly by. An air of disappointment appeared to hover over him.

"What time did you kill that bull elk, Percy?" asked Joe.

"It was just a few minutes after four," answered Percy. And then Joe said that it wouldn't have made any difference, as he had seen a couple of real good bulls about six o'clock. He told the dudes that he and Hurricane Bill had tramped into the mountains a long way; and that he was very tired.

"Boys, that Hurricane Bill is some goer. He'd just keep on going, and whispering back, 'Come on, Joe; keep right behind me, Joe.' We would go up one mountain and down another, around one side and down another, and then up. Finally he said, 'There, Joe; see that!' I looked and saw the end of an elk. I fired. Just then I saw another one. Bill says, 'There he is, Joe; shoot again,' and I shot at another one. The first one just seemed to stand there. I thought I had struck him in a fatal place and I would wait a moment for him to drop. Why, I could have knocked the eternal daylight out of him, but I was going to get the two of them. Well, I shot the second time at the second bull and expected to walk over and find my first and second bulls. I walked over to where my first bull should have Leen, and he wasn't there. I then walked over to the place where the second bull should have been, and he wasn't there. I couldn't find any trace of blcod, or anything. I can't understand it, as I thought I hit the bull squarely. Well, we didn't get anything, but it certainly gives you a thrill when you take a shot at a bull elk in the mountains. I can readily understand how a fellow would get the 'buckaggie,' all right. I didn't seem to have any of that at the time, did I, Hurricane?" said Joe, as he turned to Hurricane Bill.

"No, Joe," Hurricane Bill replied, "you never had the 'buckaggie'-why, boys, Joe never seemed to get tired, he 
just kept a-coming. He didn't have a very good shot. Each time he shot, the elk looked as if it had been hit. The first one, I believe, had Joe thought that he had not struck him in a fatal place he could have shot again. Well, Joe, that's too bad; tomorrow we'll go out and see if we can't get a real good bull."

"Bill," inquired one of the dudes, "dude Bill, what kind of luck did you have?"

"Well, I have had a good deal of scenery. I went high up into the mountains. Way over there on that mountain side over there. Way over on top. Hal and I went around some of the most hazardous rim rocks I ever saw in my life."

"Why, that dude was about to commit suicide this afternoon, by accident, of course," interrupted Hal. "He was going to jump from one rim rock to another. Why, it was several hundred feet. It didn't look that distance to him and he was just going to jump when I cautioned him."

"That's the way of it, Joe, and when I think about it, it almost gives me the shivers. I was standing right on the edge of the rim rock, just ready to jump-it was a long ways down. I saw the bottom-it seemed quite close-I was going to jump when Hal yelled, and thank goodness! Outside of that I saw some wonderful country. I saw a number of tracks and real fresh ones, to , but I didn't see any bull elk. We certainly did go a long ways and I am mighty tired. Come on, fellows, and let's go to bed," said Bill, grunting as if he were very tired.

Dude Bill stepped out of the cook tent to take a look at the weather. It was threatening. It was cold and chilling. He turned presently and passed around the cigars and cigarettes. The dudes and guides had remained in the cook tent. Ed had lighted it with candles.

"Joe," said Hurricane Bill, encouragingly, "you don't need to feel so badly about not getting those elk. We'll go back out there in the morning, where you shot, and perhaps, somewhere, we will find the first bull-you undoubtedly killed him." 
"We'll try and do it," answered Joe, "but upon thinking it over, I might have missed him altogether, yet I shot right at him. I thought I had killed him at the time, yet, maybe I missed him-I had to shoot very quickly; and then I tried to get the two of them. The next time I shoat at a bull elk I am going to keep on pumping lead into him until I knock him down. I am not going to take any chances."

"I guess that's the best way to do," said Hurricane Bill. "These elk are very hardy; they can take a lot of lead. You have to strike them in a vital place to knock them down; and if you don't knock them down they will get off in the timber and you will lose them."

The dudes were all tired and sore, so they went to bed.

Dude Percy was so tired and stiff he could barely get his clothing off, yet he was very happy. He had been successful, very successful in killing the first bull elk. As he went to bed he wondered if his trophy wauld be there in the morning, and how he would ever find it; and would some old bear come along and devour it, or eat enough of it to spoil it.

\section{CHAPTER XIII.}

The third day of September came out there in the mountains at different times to the various dudes. To one at a very early hour. There was Joe; he was a farmer and used to being up and doing early in the morning. He was usually up early, yet, this morning, he slept late. There was Percy. He had told Shorty the night before that he would be up early and that they would go out in the mountains and get the bull which they had heard bugle. There was Floyd-Floyd and Bill-they both had enjoyed a useful night's rest, after a long tramp in the mountains the day before. And then there was Hardy. My, what a hardy 
sort he was. He was always up and doing; up early and late. He had time for everything and everybody.

This morning had Joe and Percy been awake at an early hour they could have seen a very hardy individual stop at the door of the dude tent and walk over to the bed of Floyd and awaken him. They could also have heard him whisper to Floyd that if he would get up he would find a bull elk a short distance up the creek. Of course, under all of the circumstances, Floyd, upon receiving such an invitation, got up and dressed. This was no very big job, as all he had to do was to put on his socks, his shoes and his hunting coat. Floyd then grabbed his thirty-five Remington automatic and the two started out into the frosty air. They went up the mountain stream which flowed by our camp a couple of miles.

Floyd and Hardy walked on quietly until they came to the edge of the timber at the mountain park through which Shorty and his dude had passed the night before. At the edge of the wood across the park, possibly one hundred and seventy-five yards away, they saw a beautiful twelve-point bull elk.

"Powder River! Wapiti!" shouted Floyd as he awakened Joe, Percy and Bill, upon returning to camp. There was a smile upon his face, and he beamed first at one dude and then another, as he drew something white from his pocket.

"Say, boy, aren't these tusks dandies!" cried Floyd as he presented a pair of bull elk tusks to the other dudes for examination.

"That is a wonderful pair of teeth," said Hurricane Bill, "I'll wager that bull has a fine head."

The tusks were passed around and everybody proclaimed that they were the best set they had ever seen. How Floyd was pleased!. He was delighted.

"Well, Percy, I didn't kill the first five-pointer, but I've certainly killed the first six-pointer-and I have the most wonderful pair of antlers I could imagine. It is a beautiful animal, boys."

"Floyd, I want to go up and see him. Let us all go up 
and take a picture of it. I know it will be one of the best trophies we will get on the trip. Those certainly are fine tusks. Look how well they are marked! They have an eye on each one, and see how they are worn down," spoke one of the dudes. Floyd smiled again and looked mightily well pleased at what he had done.

"Floyd, tell us all about it. Tell us how it happened," said one of the dudes.

Floyd smiled and said that it was a simple little thing; that all he had done was to go out in the mountains and shoot it.

"Come on now, Floyd," demanded another dude, "tell us all about it."

"Well, boys, it was all on account of Hardy: he came around to the dude tent this morning, while the rest of you were asleep. He told me that if I would go with him he would show me a fine bull. We went out into the deer park, right up there, just a little way, about two miles, you know where it is, Percy?" (And Percy said he knew.) "Well, we walked on up there and there about one hundred and seventy-five yards away I saw the bull. Hardy pointed him out to me. I took aim and fired. I think I fired two or three times. I believe I hit the bull each time. He then walked over to a tree. I fired again and downed him. I believe the first shot would have killed him, as he bled so. much from it."

All of the dudes joined hands, and, gathering around their friend Floyd, sang the usual refrain, suggesting that it might all be very true, etc., while Floyd declared that he had given the dudes a true account of how it happened and that we could go and see it up there ourselves.

We hurried through breakfast. Shorty caught some mules and our saddle horses. We could have ridden up to where Floyd had killed his bull, yet we were so eager to see the bull, we all walked up the creek as if we were going to a fire.

The sun was shining very brightly this morning. The 


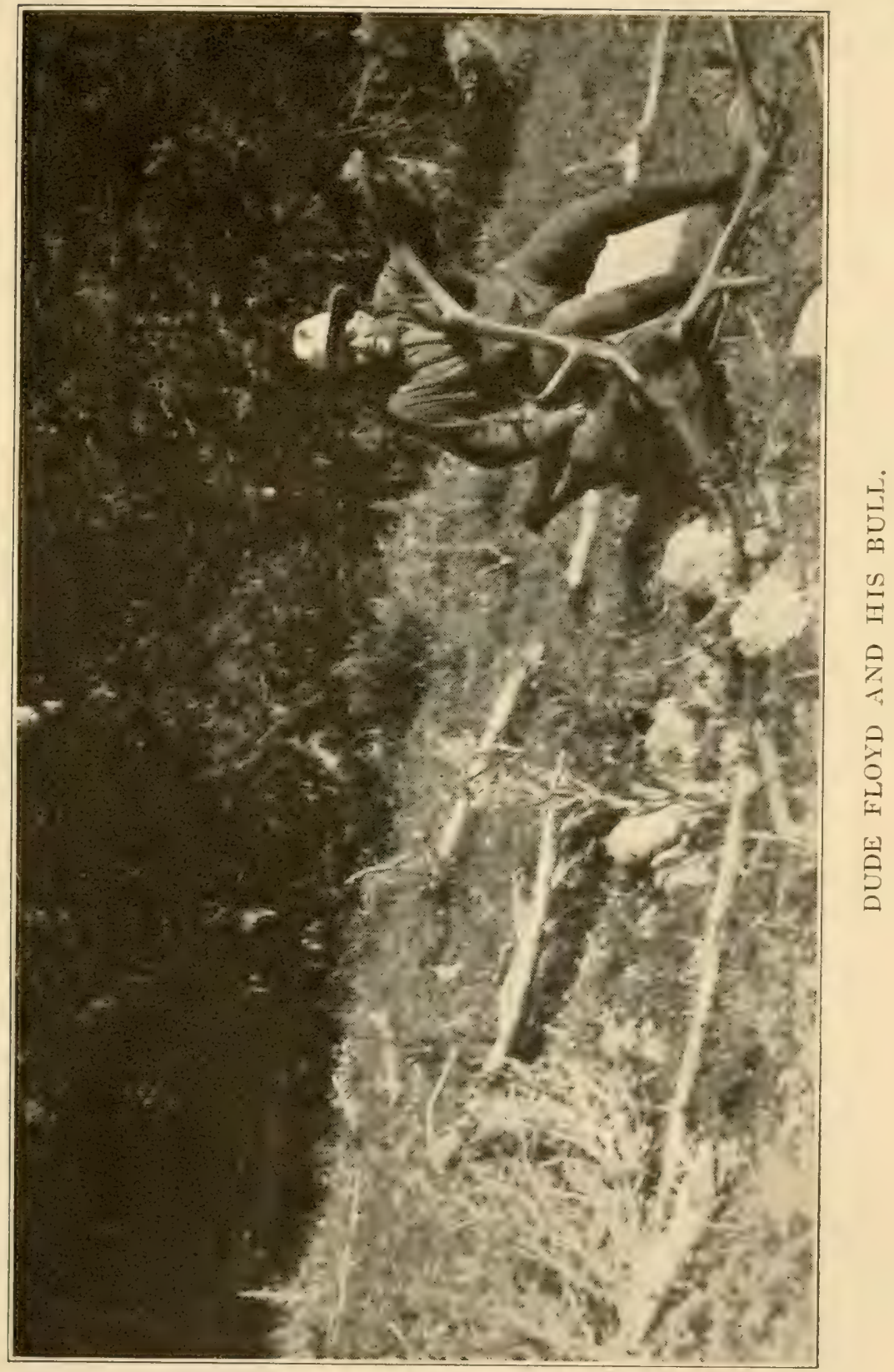



air was cold and fresh. Snow lay on the ground on the north side of the mountains. We walked on up to the deer park, and there we saw a magnificent specimen. There was i twelve-point bull elk lying upon the ground, dead. Of course, it had a pretty head-it was a wonderful specimen, and we could indeed use the meat; and Floyd in the days to come will look upon it, over his fireplace doubtless, and enjoy the happy thought of that time in his youth when he was able to climb the mountains; that time when he was able to kill the prize bull elk, on the hunting trip in Wyoming, with his friends, Bill, Joe and Percy; but as I saw that beautiful animal lying there dead, with the flies gathering around its carcass, it rather grieved me; and I know it grieved Floyd and Bill and Joe, to think that in their sport, the life of this harmless creature of the wild had been taken. Of course, it had been cut open and cleaned. Hardy and Floyd had done that.

Hardy and Floyd busied themselves in preparing and taking care of their fresh meat.

By this time Shorty came along with the horses and mules and on rode Percy and Shorty into the mountains to find their bull. Shorty had brought his pet saddle horse, Dixie. for Percy to ride. Now, Dixie was a beautiful little mare. Shorty was very proud of Dixie, and he had let his friend Percy ride her. She was an easy rider. A pretty little black pony. They rode on up the mountain talking.

"Shorty, how do you know where to find this bull elk of nine?" asked Percy.

"Well, Percy, we'll find it, all right."

"I do not doubt that, Shorty, but how are you going to locate it? What do you go by?"

"It is like this, Percy. I know the mountains, you the city. If you had been to a house in the depth of the city, you could go there. It is just that way with me out here in the mountains. I know where to go. There would be more trouble for me to find a house in the city than the bull elk in the mountains." 
We came to a place in the mountains where the water had run down the mountain side and cut a deep narrow ditch in the ground, places about two feet wide and eight to ten feet deep. Upon approaching one of these holes, Percy thought that Dixie did not see the hole; and just at that time he jerked at the bridle rein. Dixie, not being used to such treatment, threw her head into the air and missed seeing the hole. She fell into the hole and rolled over on Percy. Upon the horse falling, Percy placed his hands on the pummel of the saddle and threw his feet into the air and away from the horse, yet the horse rolled on his left arm. He got up very happy to find that he could move it. Shorty stopped and got of $\mathrm{f}$ his horse and took hold of the left arm of Percy, and examined it to see if it was broken.

"Come on, bay, you are not hurt much," cried Shorty. "You had a right narrow escape-now just give Dixie a chance and you'll be safe enough. Why, she wouldn't have fallen had it not been for your jerking her. I broke her tender mouthed-just go easy on the rein, and you'll be all right."

Percy got back upon Dixie and on rode Shorty and his dude into the mountains. They rode until they came to a place where it was impossible to ride further horseback. They then tied their horses and mules and climbed on foot. They took a saw with them and a hand ax; and in the course of an hour or so they had the elk quartered and carried down to the horses. It was a job-carrying all of this meat down from the high place in the mountains; and then it was another job tying it upon the back of the mules.

The law of the state of Wyoming is very strict in this, that it requires all of the hunters to care for any of the game they kill in the mountains. They are to take the meat to camp and use it. It is a felony in the state of Wyoming for a person to leave a bull elk carcass, or the carcass of any big game, in the mountains to waste. Of course, we needed the meat and we brought it all in, as well as the head and antlers. The hind quarters on the back 
of one mule and the forequarters on the back of another mule.

Shorty and his dude rode on back to camp. They reached camp about noon. They had done a big day's work.

Floyd and Hardy had returned to camp with their meat. We now had all of the meat we could use for the next several days, and some to jerk.

IVe sat down to a dinner of fried elk tenderloin. Now, fried elk tenderloin is a very good meat to eat in the mountains. It is not as good as corn-fed beef, but it is about as near that kind of meat as any meat I have ever eaten. It was very good. We all enjoyed it very much. We ate any number of pieces at a meal.

"How many pieces of elk meat did you eat, Shorty?" asked Floyd. And Shorty smiled and said that he had eaten six or seven that he knew of, yet he didn't remember exactly; and that it was so very good, he would just help himself to another piece.

We were slightly lonesome for dinner. Joe, Hurricane Bill, Dude Bill and Hal were not with us, they having remained in the mountains.

"Well, Shorty, how do you prepare a scalp?" asked Percy as he took a good seat to view the operation, after our lunch had thoroughly settled.

"It is a hard thing for me to tell you. Come over a little closer and you can see." Percy walked over closer and sat upon the ground while Shorty whetted his knife.

"The first thing, you skin it over the shoulders, leaving the head; then you skin around the horns, like that, see," said Shorty, as he stopped to illustrate and sharpen his knife; "and then you take your knife and cut the skin away from the skull, the head and the lower jaws as well, being very careful when you cut the skin around the eyes; next over the nose; see," and Shorty held up the specimen.

"Just a minute, Shorty; let me take those tusks out," shouted Percy. Percy took out his pruning knife and dug the tusks out of the right and left front sides of the lower jaw. 
Shorty went on preparing the head of the elk and soon had removed the skin of the elk from the head.

"Why, they are very good teeth," said Shorty, meditatively, as he passed them over to Ed, who had stopped his work to examine the tusks. Ed took them and studied them carefully, saying that the teeth "bane much better than the heads bane," also stating that while they were not as good trophies as the tusks of Floyd, yet they were a very good pair.

"My goodness, Shorty, that's a big job," said Percy, as he noticed Shorty was again working on the elk head. He was now fleshing the hide, cutting the meat off of the hide: and then the skull had likewise to be fleshed.

"Yes, it is quite a job to prepare an elk for the taxidermist. The better it is prepared, the better mount you will get," and Shorty kept on cutting the flesh away from the skull, so that his dude would have a first class mount.

"Of course," added Shorty, "after you take the skin off of the top portion of the mouth and the skin off of the jaw, then you take off the lower jaw-like this," and Shorty pulled the lower jaw off and apart, "and then you cut out the tongue; and then you can take a saw and separate the skull, so that you can carry it on horseback."

"Say, Shorty," shouted Percy, "what's a matter with the hide? Can't we use that? Have it tanned?"

"Well, it would make a pretty good rug, but you see you have taken off a great deal of it for the mount of the head and shoulders. If you do not care to mount the head of the next elk you kill you can have a rug made out of the hide. Yet the rug would not be as good as a bear, or a fur animal."

The preparing of the heads took most of the day as far as Floyd and Percy were concerned. They were very tired, and were very glad for the opportunity to rest. Percy found a very comfortable seat on the bed of Shorty and a book which Bill had brought with him. Floyd also found a book, and these two dudes read most of the afternoon, while the other dudes did the hardest of work imaginable- 
hunting in the mountains. Of course, any number of times Floyd and Percy would get up from their books and take a look at their respective trophies. After the heads were skinned out the hides had to be salted, the salt rubbed into the hides. The skulls also had to be salted. With this preparation the hides were stretched out to dry and the skulls and antlers piled in a convenient place near camp.

"Joe, did you have any luck?" shouted Percy as Joe and Hurricane Bill came to camp. The two were tired and did not appear particularly elated, although there was a smile on the face of Joe.

"We saw a great many things," said Joe, continuing: "a bull moose-these bull moose are rather peculiar. They don't give a rap whether they give you the road or not. They have a notion of their own about their rights, and look a great deal as if they know that they are protected."

"The cows," interrupted Shorty, who had come up to the dudes to hear the news, "will give you the road, but the old bulls, they have a different disposition."

"We were out there in the woods," Joe spoke on, "in the mountains, and there stepped out old Mister Bull Moose. $\mathrm{My}$, he was a big animal. He had a magnificent head and paddles. I could have killed him easily. He was standing there, standing still, looking at me. I had my gun all ready, when I heard Hurricane Bill say: 'Joe, don't shoot. Don't shoot!' I stopped and recalled the law upon the Bull Moose. I stood there and watched old Mr. Bull Moose-he didn't care whether I did or not. While I was watching him he walked off casually into the timber. I'm mighty tired, boys; we've tramped and climbed everywhere."

"Whew !" cried dude Bill; sighing wearily, as he reached camp, "this has been a terrible day on me, fellows. I'm dead tired. We have been up one mountain and down another. When we were on top of the mountain we could look down and see elk, about a mile below, and then when we would get down where we thought they werc we could see them 
up above. It was up and down, up and down. Oh, my goodness! I'm all tired out."

"You bane hungry, Bill?" said Ed, pleasantly. "You bane better sit down and have a hot bowl of soup. It bane very nice." Bill dragged himself down to the river and washed. Upon his return he was served a hot bowl of oyster soup and supper.

This oyster soup was made from canned oysters and "tin cow," and while it may not have been the best oyster soup in the world, yet it tasted very good.

"Well," said Bill, stretching, "you boys can play pitch, go hunting or anything, but this dude is going to bed shortly. Suppose Percy, that lucky sport, has had a big bull come up and eat salt out of his hand? You haven't? Well, I'm surprised. Gee, fellows, I'm tired. This chasing the bull has almost got my goat today."

All the dudes, while they were very tired, were able to eat a large dinner, yet, after dinner, they sat about the camp fire listlessly a few moments and one by one went to bed.

\section{CHAPTER XIV.}

Oh, how comforting and soothing the bough beds were to the dudes. How they were enjoying themselves sleeping this morning. It would indeed be a shame to awaken them.

"Here, you dudes," shouted Hardy, "going to sleep all day? Wake up, Percy! Get up, Floyd, Joe and Bill." And as the dudes raised themselves from their warm beds, stretched and yawned, they saw the face of Hardy. He was standing over them laughing.

"Come on, Percy!" shouted Shorty, "come on!" Will Percy ever forget that everlasting come on; how it taunted him. It was ever, come on!

"All right, Shorty; just let me get some of the kinks out of my back. Oh, my goodness. I'm stiff and sore this morning," his dude answered as he stretched himself. 
"Come on, Percy. We'll go in the mountains in a different direction today. Why, you rested all day yesterday," urged Shorty, having forgotten the half day he and his dude spent in lugging the elk from the top of a high mountain. "Come on, boy. I've caught up the horses. We'll go for a ride ; come on!"

The dudes got up, slid into their trousers, socks and shoes. Breakfast was ready, and from the way they ate, they were ready for breakfast.

Dude Bill had grown slightly disgusted with his hunting country, so he and Hal, Hardy and Floyd had prepared a pack for a trip into some distant mountains, where they expected to spend the night and be ready to hunt early the following morning, while dudes Joe and Percy believed there was a great number of elk in the nearby mountains. "Good luck, Joe, you and Hurricane, Bill and Hal," shouted the remainder of the party to their friends as they rode away with their pack, which consisted of two teepees, supplies and beds.

Immediately upon the departure of these dudes Floyd and Hardy were seen whispering together. They were ready for a trip in the mountains, and so were Shorty and his dude; and in different directions they rode away, while Ed remained to do the camp work.

Shorty and his dude rode into and over the top of the mountain range, which was at the head of the creek that flowed by camp. As they neared the top the climb became very steep. The altitude affected Percy very much. He would have to stop every few yards. Nearing the top, he was about to give out from exhaustion, and would have had it not been for the suggestion of Shorty, urging him to hold onto the tail of his big horse.

"There, Percy, catch onto his tail; hold it tightly, and he'll pull you up. Oh, he'll be too busy to kick, and then, if he were to, you can dodge. There, catch hold. Now, come on!" Oh, what a picture. There was Shorty's dude- 
and a right ornery looking dude, too-his whiskers had grown, so that his face resembled a large cuckleburr; his woolen socks were over his trousers, and the garters on the outside; his underwear about two inches above his trouser line; his hunting coats were tied around his waist, the backs of which were hanging over his hips and nearly dragging the ground; his woolen shirt was open two or three buttons, and he appeared to be in the act of sliding out of all of his paraphernalia, or being drawn out by the big horse ahead and the gray horse behind, as he held firmly onto the tail of the one and the bridle reins of the other. In this way we climbed to the top. Oh, how good did I feel to get on top. I was not so tired. There was plenty room on top, as there ever is everywhere. We rode on over into another mountain range, keeping, as nearly as possible, on the top and above timber line. After we had ridden a short distance we saw a herd of about one hundred and twenty-five elk, cows and calves, and a few small bulls, which Shorty called "spike bulls"-bulls not much over a year old. The cows were alert. They looked as if they were aware of our presence in the mountain. One old cow raised her head high into the air and sniffed. Shorty and I had slid off of our horses, tied them behind a pile of big rock, and were ourselves hiding behind another pile of rock. We remained very quiet and watched. Fortunately the wind was blowing from the elk. Presently the old cow elk quit sniffing the air and began to graze, and so did all of the herd. We saw the herd grazing in a long line of twos, threes and fours. At each end, and on each side, were cows, which were ever alert, while the rest of the herd grazed, carelessly wandering on. Finally one of the cows raised her head and sniffed the air. She gave an alarm. The herd became nervous and started walking here and there, or, as the guides put it, "milling around"; and then all of them started on an easy trot, following a leader, while one of the cows remained to ascertain exactly what the trouble really was. 


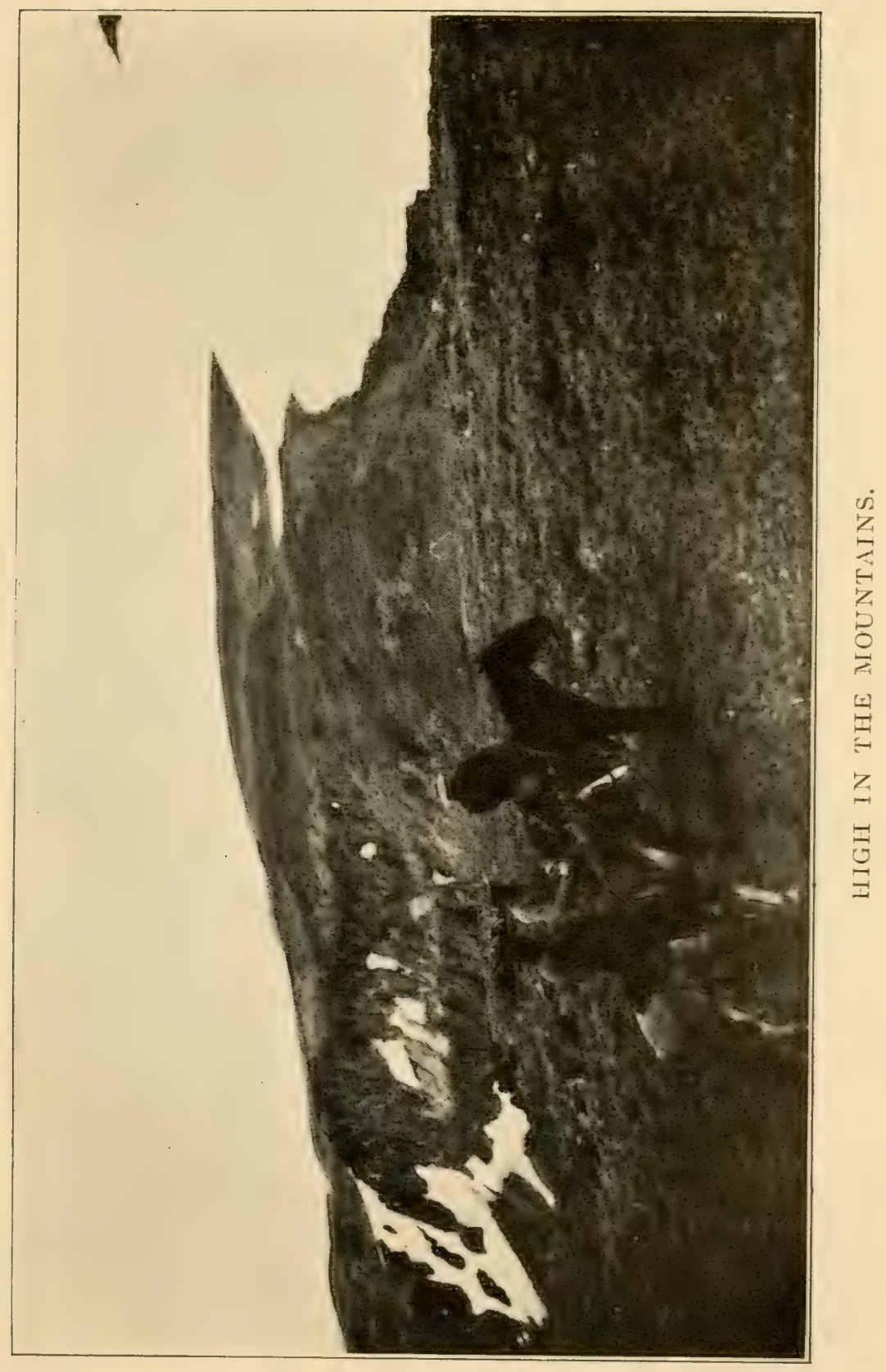


IVe went back to our horses and mounted, and rode on in the direction the herd had gone. We saw them after a short rile feeding on another mountain side in the distance in the same manner. As there were no large bulls in this herd we left them without disturbing them.

We were now in a wonderful place indeed, in the midst of snow-covered mountains. Huge banks of snow lay here, there and everywhere; and in just such a place all of the dudes went on many occasions.

Shorty and his dude rode on over the top and across the lutge bank of snow. It was frozen and solid. The top of it was covered with a coarse granulation of snow. We rode on for a number of miles and into another mountain range. The air was chilling and a cold wintry wind was blowing. As we rode we looked over and down; we saw a good sized bull elk.

"Come on, Percy, let us take a good look at that bull," shouted Shorty, as he turned his horse and galloped down the side of the mountain. The mountain side was very steep, and composed practically of loose rock. Shorty soon reached the place where he had seen the elk. He turned and yelled back to his dude, and then galloped on. The dude rode on down, very glad to find his old gray did not care to further risk their lives at any livelier gait than a trot. This mountain side went down for perhaps a mile, to the basin of what I was told to be the Snake River of Idaho. As we rode on dow 1 the sun shone just the same as it did when we were on top, yet it gave out a warmth which bade us good cheer. We came into a beautiful deer park.

"What a dandy place for elk," whispered Shorty; "let us tie our horses and rest a while, and in a short time we may see a great bull." And his dude quickly acquiesced.

We laid down on our backs in the shade of a small spruce tree and went to sleep. The dude of Shorty was awakened by the snores of his guide, and thought that they might have been a warning of some wild animal, yet upon awakening 
found everything peaceful and quiet. The big horse of Shorty had untied himself.

"There goes your horse, Shorty," whispered Percy, as Shorty awakened; and Shorty replied that the horse had gone for a drink and would return and hunt us up after he had a drink. The horse walked leisurely to the river, took a good long drink and sniffed the air, turned, and walked directly up to where we had been sleeping.

We realized that we were a long, long way from camp, hurriedly mounted our horses and started at a gallop. Up the steep mountain side we climbed after we had reached it. We had forgotten the distance we were in the mountains. We rode on and on. It was growing dark, yet we always had time to stop and examine a fresh track. There were a great many-bear track and elk track-tracks of large bulls. The sun had begun to sink behind the mountain range in the west. It was growing cold, dark and dismal. We were winding our way back. We rode on up to the top of the mountain and then started down in a different direction. We encountered a great deal of fallen timber. It was quite dark, and riding through this fallen timber gave dude Percy any number of thrills.

On down and through fallen timber, and around a rocky slope, rode Shorty and his dude. The dude had let his horse have the rein. He was trusting more in him than any other power. The gray horse with his pack climbed on down. $\mathrm{He}$ came to a large log, lying directly across the mountain side and in front of him. The horse stuck his nose over it. It was about two or three feet in diameter. The horse jumped straight out into space, over the log. The dude lost his breath, but grasped the saddle firmly with his legs. As they went through the air he looked into space, and down, seeing the tree tops below. He wondered if he and his horse would ever stop. There was a sliding and grinding of small rock under the hoofs of the horse. The dude and his horse slid together. The horse reared back on his rump as he slid 
down-while the mind of the dude was in a whirl-and then the horse and his pack stopped.

"Safe, boy! Just as safe as if you were in the arms of Jesus. Oh, come on!" shouted Shorty, who had stopped and had watched keenly the flight.

Shorty and his dude reached camp in time to be served a dinner of elk meat, and the fat of the land. It did indeed taste good. How all of our party did eat.

Floyd and Hardy came in. Floyd was tired tonight, yet he wore a smile on his face. He had seen a number of elk-cows, yet he had not had a shot at any bulls.

"It bane look like we are going to have a snow," drawled Ed; "it looks like we bane gone to have the equinoctial."

Everybody hoped we would. Shorty assured us that it would not surprise him to see four or five inches of snow on the ground in the morning. It didn't make any difference to the dudes what happened. They were ready for what fate had in store for them, so let come what would.

"Let 'er snow," said Floyd, as he said goodnight, while his bunk mate voiced the same opinion, stating, however, that he would appreciate it very much if Ed wouldn't snore quite so loudly in the early portion of the night, adding that it reminded him of midnight at the zoo.

\section{CHAPTER XV.}

Floyd and his dude friend awakened this morning to find a wet, cold snow falling. The surrounding mountains were dressed in white. Everything was cold and still.

"Powder River! Wapiti!" broke the still morning and summoned the camp to attention.

"The wanderers return," shouted Shorty, while Ed saicl something about their bane in time for breakfast and that he bane suppos'n they didn't have enough supplies with them and would be back; and, as this was his notion, he had breakfast ready for them. 
The dudes and guides, as usual, ate heartily. After breakfast they smoked and wondered how long they would be confined to camp.

"Say, dude," shouted another dude, laughing, "didn't J hear you say something about taking a bath this morning?" And the dude said that he had expected to, and Hardy put in and suggested that the door to the bath was still open, while the dude looked about him and saw the snowflakes falling, and felt the chill of the morning air. Of course, the dude had suggested that he needed a bath-and I dare say all of the dudes did-yet this dude had admitted it; and having admitted it himself, he surely needed one. It would indeed be unkind to his friends to associate with them after having made such an admission, notwithstanding the fact that all of them may have needed the bath themselves; so the dude in question, rather than be assisted in the fulfillment of his purpose by a crowd of "jollying" dudes and roughnecks, decided that he would not let such a little thing as a snowstorm knock him out of his bath. So off went his woolen clothing, socks, coats, shoes and all. He tripped merrily to the river as nature had presented him to this old world, to take again the first thing he had ever received in life-a bath; and while it might be considered worse than medicine to take-and, to say the least, I think, it was a "wee bit" refreshing-yet on went the dude to his bath singing merrily something to the effect that while the water was fine the snow bath would indeed be divine.

"Now, I really will be d-d," shouted Mr. Hardy Shull. At this moment another dude stepped close to the side of the dude on his way to the river; and as the two dudes reached the water's edge, one dude gave the other a pushwell, the barefoot boy slipped, but before striking the water caught the other dude by the heel. So up went the feet and down went the dude. The falling dude, who was dressed warmly in hunting clothing, grabbed hold of a small spruce tree and hung on as if he were about to fall a mile.

"Oh, don't. Let go! I didn't mean to push you so far. 
Don't pull me down on those rock," cried the struggling dude.

"Aw, pull him on in," yelled another dude, "It will serve him right," and the barefoot dude gave the other a yank, while the dressed dude held on to the tree for what appeared his dear life, kicking dexterously with his other foot. The barefoot dude grabbed hold with both hands and started to twist, and as the face of one grew very red the other smiled, and the barefoot dude, upon realizing that he was standing in the icy water, and then, too, that he might carry the play too far for their ultimate pleasure, let go of the clothed dude and went on with his bath, while the other members of our party had a good laugh.

"Good morning, boys!" shouted the dude who had taken the fresh bath, upon returning to the cook tent, where he found the rest of the hunters gathered around the fire. $\mathrm{He}$ smiled a rich, healthy smile, and beamed on first one and then the other. "Aren't you dudes ever going to take a bath?" And the fresh dude struck the other one, who had scuffled with him, a friendly blow upon his shoulders, nearly knocking him and the cook tent over, interfering slightly with the business of the cook. The cook suggested that there was a certain frisky dude who bane so gay that if he didn't take care he would get a skillet hung over his head.

"Dude Bill," shouted one of the dudes, "tell us about your trip up in the mountains; did you have any luck?"

"Well," said Bill, after the gang had quieted, "we didn't have any particular luck, except we saw a herd of about fifty elk; another herd of about fifteen, all cows and calves; then we saw one fawn deer. It was a beautiful little animal. We didn't take a shot at anything. We were looking for a big six-pointer. We certainly had a good tramp. Say, boys, we were tired! And we returned at night to about the worst bed I have ever slept in; right over a big pile of rock; and I believe one of them is still sticking in my back," Bill added, as he stretched. 
After dinner it quit snowing and the air grew fresh and cold. The dudes had been sitting about the cook stove.

"Come on, Percy, let us go up into the mountains and see what's up there!" So Percy and Shorty started.

Hurricane Bill and Joe were seen talking quietly. They appeared always to be plotting against the things of the wild. They walked of $f$ down the creek.

Hal and Bill were pretty tired, yet they had an idea as to where they would find something interesting, so on they went, walking in the direction Shorty and his dude had gone the day before.

About six o'clock our party met at camp. We were all very tired. We washed and made ourselves ready for supper.

After dinner we built a campfire. All of the dudes stretched themselves out on the ground. Bill was smoking a cigar with a nice gold band about it, while the rest of the dudes smoked pipes. The guides, they were all smoking, excepting Shorty, and he whittled a stick, while Hal smoked any number of cigarettes.

"Oh, isn't a campfire grand! Say, fellows, I think this is a great picture. I wish I had some flashlight," said dude Bill, and we all did.

"I wish you could see your face, Bill," shouted Floyd. "Why, you are a veritable grizzly bear, you old, graywhiskered dude." And Floyd put a chunk of wood on the fire while dude Bill rubbed his face and chin, suggesting that he had grown a little beard today; that he had a shave this morning, yet it wasn't very close.

"Go on and shave, Bill," shouted Floyd; "see if I care." And then Floyd told us of a bet he and Bill had, that they were not to shave until they reached civilization, at the penalty of spending a new, crisp fifty-dollar bill on the gang.

At this point one of the other dudes suggested that we "rope 'em and shave 'em"; yet as the two appeared as if they could not possibly stand to win the bet, no violence was attempted. 
"What's the luck today, hunters?" inquired a dude.

"Well," said Joe, "I got my elk today. I got a six-point elk. I have a pair of tusks, see there!" and then Joe passed around a beautiful pair of tusks. All of the dudes and guides thought that the tusks were wonderful. Joe scratched off the little flesh which remained near their root and polished them by rubbing them on his trousers, and then very carefully put them back in his pocket and pinned it together.

"Come on, Joe; tell us how you did it."

"Well, Bill and I had gone way up into the mountains, just about where the rimrock begins. Bill just kept on saying, 'Come on, Joe; come on, Joe,' and I kept a-coming. First thing you know, he says, 'Joe, there he is,' and I drew down on him and shot. Bill says, 'Shoot again, Joe; you've got him, knock him down.' I shot again, and then I struck him with the ball over the shoulders and knocked him down. When I went up there, why, that old bull just raised right up and was going to paw me, so I put a ball through his head to put him out of his misery. Why, that old bull looked as if he would have kicked all of the daylight out of me, if he only could. We then cleaned him, propped him open. We've had an awfully hard day; we've certainly worked, Hurricane and I. It was a pleasure to see Hurricane butcher that elk. Say, boys, he's some butcher."

"All of these guides-they are butchers, cooks, horse wranglers, and most everything," interrupted Floyd. "Why, I noticed Shorty making bread, and saw Hardy cooking breakfast. And both the bread and breakfast were good to eat. They know something about everything out here in the mountains. Gee, they are a versatile bunch."

"What did Dude Bill do?" asked Floyd.

"Hal and I went up in the mountains. We went way up above timber line, and then we walked down over some loose rock, and around any number of boulders; and walked, and walked. We saw a good many tracks, evidences of bear. We saw one big bull's track, but we never got in shooting 
distance of anything. I'm getting awfully tired of my luck. I thought I was going to get a bull, but it looks like fate is against me. Say, Percy, you are awfully lucky; what kind of luck did you have?"

"It does seem that I have a good deal of luck," said Percy, looking as if he really believed what he was saying, as he took a drag at his pipe, shifted his position on the ground so that the smoke of the campfire would not choke him, continuing: "Yet maybe I should lay all of my good luck to Shorty, or," and Percy hesitated, as if to think seriously, "well, such has been my life today. I want to tell you fellows I never have received such punishment in all my life, in any capacity, as I have since I have been following Shorty around these mountains, in these old shoes. $\mathrm{My}$, if there ever was a fellow I had a grudge against in the world, it is that man who sold me the wrong pair of shoes. Oh, that little, old, short-legged boy can bounce along. It was always, 'Come on, Percy! Let's bounce along.' Shall I ever forget it? Never. And we had bounced, slid, climbed, ridden, and gone in most every bad and dangerous place I think there is out there in the mountains. Well, we finally got to the top. We had been riding very comfortably on top. We were a long ways up-so far up that Shorty had suggested that I may never get nearer heaven-and if that place is higher up and harder to get to than where we were, well, God help a poor sinner like me. Well, we were up on top. How grand it is to be up there and look about! From there we could see almost everywhere. However, we were never satisfied, ever riding on. We came to the edge of a terrible precipice. We dismounted; tied our horses back from the edge. We expected to see something and we didn't want to attract much attention. We crawled over to the edge and looked down-and oh, so carefully, did I look-we looked down and over, and in a high pocket in another mountain saw two immense bulls. They were about the size of Floyd's. 'Slide on back,' whispered Shorty, 'get on your horse and follow me. 
Do what I do.' We slid on back and mounted. Shorty turned and looked in different directions hastily, and then spurred his horse over what looked to be a great precipice. 'What,' I whispered excitedly, 'do we go down there?' Shorty urged me on. The way Shorty had gone led around the side of the mountain. It was a very steep side of a mountain of loose rock. It went down, ever down. Shorty came to a place where he dismounted. I got off. I tied my reins together in a hard knot and went on down, following Shorty. Finally we came to a place where the rimrock went down about a quarter of a mile, straight off and down. Shorty had climbed safely around a boulder, a very narrow path, up close to the mountain. He led his horse as he went and carried his rifle. I had my rifle in my right hand, the rein in my left. I had come to a place where horse and rider might fall into eternity. My horse hesitated-my feet slipped clear out from under me-and there, boys, your friend dangled, between this world and the next, rifle in one hand, my very life in the other, holding onto the bridle reins. I was afraid to scramble much, fearing I would pull my horse into my position and we would both go down into the abyss. Oh, but I almost did let go of the reins-they were nearly jerked from my grip (and it was a death grip, too), when my old gray horse-and Gad bless and reward him for his heroic act-he simply snorted and reared back on his haunches and pulled me back from the great beyond to a place of safety. And then, oh, so carefully, did I climb around the boulder, and oh, so carefully did I lead my dear old gray on.

"'What's matter up there, Percy? Come on! We'll miss the elk. Make that old gray devil step along,' Shorty cried to me in an under bieath. And while I knew Shorty meant no harm to my good friend, the gray, it rather hurt me to hear him call him an 'old gray devil.' On down, my good gray and I went, following Shorty. We slid, caught ourselves, and in the course of a struggle, which I know was just such as all of the dudes have had, we reached a place 
where Shorty thought we had better tie our horses. We tied them to a scrubby tree. On down we went and then we started up. I stopped at the edge of a rivulet which was forming from a snow bank and drank. Oh, how refreshing. I bathed my temples and face. 'Come on, Percy,' whispered Shorty, 'come on.' I stumbled on. My rifle was beginning to bear me down. My heart was beating heavily. I turned on the last ounce of will power and climbed on. We had reached the high pocket. 'There are the bulls,' whispered 'Shorty; 'come on; you want a better shot.' I went on a few steps, took aim and fired. I was within a hundred yards of the bull. I saw a little red spot come on the side of the bull. He walked slowly on up and then disappeared. 'Come on,' again whispered my friend Shorty, but this time, boys, my feet would not hold me. I sank down from my exhaustion, and tried to lie on the mountain side to rest a moment. I slipped and slid on down, and struck against a stump of a small tree. There I stopped. Shorty went on up and watched the bull go into another portion of the mountain. I regained my wind and looked about me. Immediately below was a rimrock-a drop of a hundred feet or so. There was a lot of room for me to slip by the tree stump, yet I didn't; and you dudes are not troubled with a mangled corpse-and why?"

"Percy, you have a hell of a time, don't you?" laughed Hardy, who added that every now and then they had to carry a dude back on a pack mule.

"Come, Joe," said Floyd, "tell us what you had to do."

"Well, fellows, I wasn't suspended over a precipice. I just went up and got my meat, and brought it all in; and Hurricane Bill and I got into some of the worst places I could ever imagine-"

"Boys, we have forgotten something; ready, fellows, sing," shouted Floyd, and the whole tribe joined in on that old, well-worn chant, suggesting that it may be so, etc., while Percy added that he was mighty glad to be joked and 
hear their voices; especially, happier than to be the cause of, maybe, a heap of sadness.

"Well," said Floyd, seriously, "I have just had a similar experience. Hardy and I went out into the mountains. Up above timber line, up on top of the mountains, and walked. We slid around some rimrock, and I tumbled; I lost my balance, fell down, not a mile or so, but a short distance, and bruised myself all over. I certainly had a rough time. We finally got back to camp. I am mighty glad to be here. There was a time when I had my doubts of ever reaching home again. Say, let us go to bed."

Dude Bill stepped forth, and the dudes formed a circle about Floyd, and around him they danced and sang; and the mountains echoed and re-echoed with the grand amen.

\section{CHAPTER XVI.}

The morning of September the fourth, nineteen hundred and seventeen, found the dudes sleeping late. They loafed around camp. Joe and Hurricane Bill went into the mountains to get their elk meat, returning about noon.

"I don't know what's the matter with these heads, the antlers, unless it is that the elk didn't winter very well," said Hurricane Bill, as we all gathered about the new trophy of Joe. "I think," he continued, "it is on account of the fact that last winter was very hard on them; and then it is on account of the fact that the ranches have been encroaching upon their country, constantly taking from the elk the low country where they used to winter. It is my experience that whenever we do not have a hard winter the following year the elk have heavier and larger horns. What do you think about that, Hardy?" Hardy and the other guides were of the same opinion, while Ed added that "they bane stay too high in the mountains."

We now had plenty of meat. We started to jerk the 
meat. We thought that by the end of our trip each ducle would be able to take home with him approximately four hundred pounds of jerked elk meat.

"Hardy, how do you jerk this meat?" asked Bill, as all of the dudes gathered around to see.

"There's not much to it, Bill," said Hardy, "it is very simple. All you have to do is to cut a hind quarter, like this, so that you can catch hold of a piece, about as big as your forearm, and then jerk it off. When you jerk it of $f$ the separating tissue forms a skin, and this skin, after you hang the meat up and smoke it, gets tougher; it protects the meat. Now, then, after you jerk a piece off of the quarter or loin, you run a cord through it and then we hang it up and smoke it." Shorty had already cut six poles, four about like table legs, and two about six or eight feet long. He drove the four into the ground and nitched the other two so that they would fit over the tops of the four. A smudge fire was built. The jerked pieces of meat were hung on the poles, and then we covered the poles and smudge with a tarpaulin, kindling the fire and then covering it with green shrubs and grass, which would burn slowly and smoke.

After jerking all of the meat we did not care for for immediate use, we washed, and were served dinner.

Bill and $\mathrm{Hal}$ had been plotting together against the elk, from time to time, during the morning. They decided to go out in the mountains. Shorty's dude was so tired and his feet were so very sore that he didn't care very much about going anywhere, yet just to be company for his guide he picked up his rifle and started, though he took a considerable time to get ready.

"Come on, Percy," shouted Shorty, who, as the men of the West put it, was "rearing to go."

"Oh, I'll be right there with you in a minute. Now, I want to tell you something, Shorty. I am tired, and sore and stiff, and if you are going to run all of the way, I think I shall stay in camp." And Shorty told him again to come 
on, and that they would take their time, so the footsore dude marched along.

Shorty and his dude limped on up a game trail, which led up the mountain stream to the left, one which emptied into the stream which ran by our camp a few miles down the stream. We crossed the mountain stream, climbing on up near timber line. On our way we saw a buck deer. Every few steps going up Shorty and his dude would stop and rest. They were hunting leisurely. They had climbed up a mountain side of loose rock. Here and there was a scrubby tree, or some small brush. At this particular stop Percy had so tired of hearing Shorty urge him on that he climbed a few steps ahead of Shorty and stopped to rest. The two sat down to rest. The side of the mountain was so steep that they sat down on their right foot and braced themselves with their left, resting their rifles across their right thighs. We were ready for most anything, and each one had little expectation of seeing anything at that moment. We were whispering about where we thought we would find a bull.

"Now, Shorty," whispered Percy, he having thoroughly regained his wind, "let's go on up the mountain. I am rested. Isn't it wonderful how quickly a climb gets your wind, and then how quickly you get it back," Percy whispered. Percy was in the act of rising. He looked up. He heard a sound which resembled an earthquake. All of the mountain appeared to be coming down on the dude. There, immediately above him, approximately thirty-five to forty feet away, charged a huge grizzly bear. Her mouth was open wide. She roared! The dude stood there and looked into her very jaws of death. They were opened wide, wide enough to take in the whole head of the dude at one gobble and strong enough to crush it. Her long white teeth glistened. Her tongue was pulled back; her lips raised so that the dude could see all of her teeth. She was all bristled, and her hoggish eye was fastened upon him.

Under these circumstances, my dear friends, what would you have done? 
Just as the sun had gone down behind the mountain range on the west, two tired looking individuals arrived at camp. They had worked hard that day at their sport; a dude had risked everything and now he was the proud possessor of the king of all trophies. Shorty was wrapped in the hide of a grizzly bear, while Percy had a large bundle on his back.

"Powder River!" yelled Percy, in his endeavor to call the dudes to see what he had procured. He dropped his bundle on the ground, and then helped unwind the grizzly hide from around Shorty and stretched it on the ground. Percy then stood and looked at the hide of the monster. It measured seven and one-half feet from the tip of the nose to where its tail might have been, and had an eight-foot stretch.

"Percy, my friend, I bane mighty glad you got a grizzly. She's the queen of 'em all. No better trophy will be taken from the mountains; you bane lucky boy. You know, Percy, they bane fast becoming "instinct," "said Ed, as he leaned back on his hips, resting the back of his hands, and gazed steadfastly. And then Percy and Shorty stretched out the fur, combed it out. We found the fur in excellent condition considering the time of the year, and decided that old Mrs. Bear had been spending a great deal of her time high in the mountains.

"Well, Percy," shouted Floyd, as he approached, "you look mighty dirty and happy; what luck?" Percy pointed to the grizzly hide.

"Well, I'll concede that you are the luckiest dude in the party. Suppose you killed the bear."

"That he did," shouted Shorty; "that he did. And here is her hide." Floyd examined her very closely, and Percy repeated that Ed had told him she bane rapidly becoming "instinct," while Floyd said that there appeared to be more "outstink" than instinct. Percy stood and viewed the trophy, looking seriously at her huge head and mouth.

"Well, Percy," said Floyd, "tell us how you killed it?" 


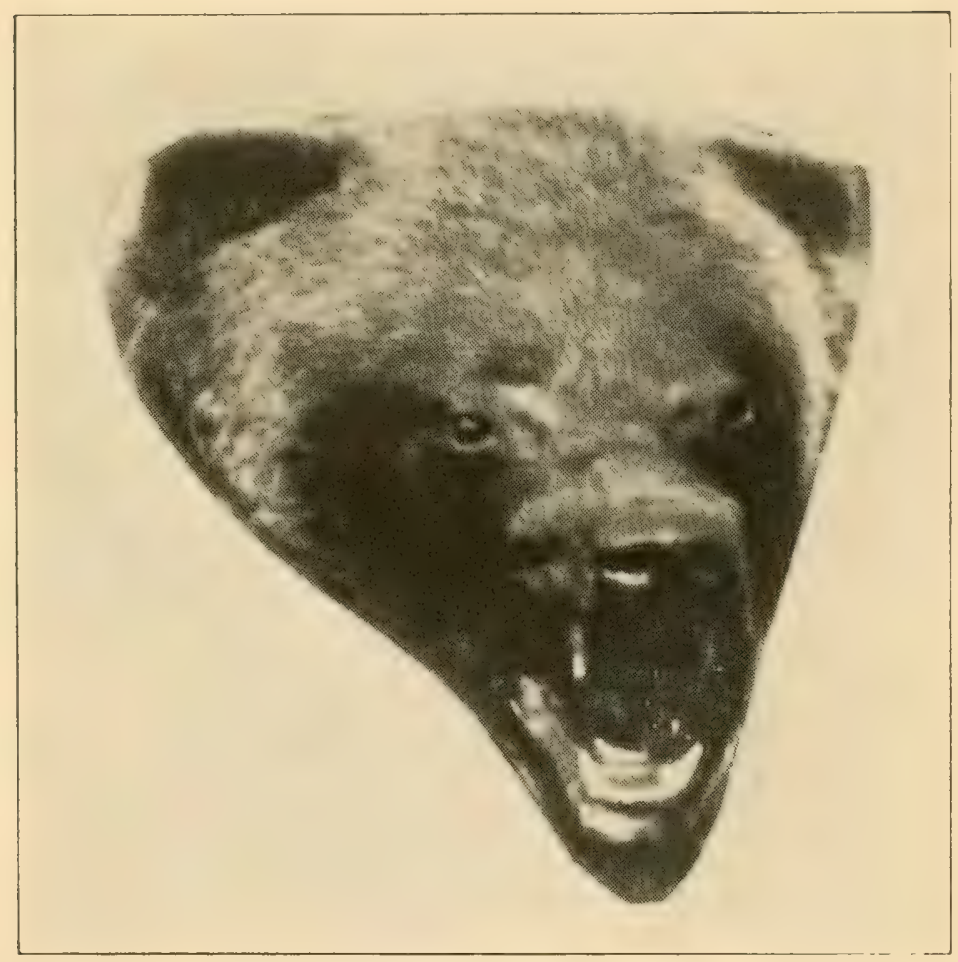

THE KING OF ILI, TROPIIES. 

Percy filled his pipe slowly, stood and stared at the pelt of the monster. He told his friend he would rather wait until the whole party were there, as he expected he would have to tell how it happened a great many times and that he might as well begin to lessen the effort.

"Well, Shorty," spoke Floyd, "you tell us."

"It was a very simple thing," said Shorty as he reared back on his hips, bracing himself with his wrists on his back, so as to well balance his high hat, "very simple. The old bitch charged on Percy and me. Percy raised up and shot her; and then we had one hell of a job. Come on, Percy, let us go to the river and wash some of this 'instinct' from us."

Bill and Hal came in.

"Percy, for the love of God, did you shoot that bear with that small gun of yours?" cried Bill in nervous astonishment.

"That I did, Bill," shouted the dude from the river.

"Well, I want to hear all about it, but I am so blamed tired. Come on, boys, let us eat dinner," said Bill as he took another look at the grizzly pelt.

The dude, who had an odor about him very kin to that of a grizzly, came from the river, singing, to the tune of "Goodbye, Girls, I'm Through," "I'm the happiest boy in all the mountain kingdom"; and he was.

"Boys, I know you bane having a great deal of fun looking at that grizzy bear," shouted Ed, "but dinner is getting cold." And Hardy suggested with his leather voice that we should "come and get it, before he spit in it."

Joe and Hurricane Bill had not reached camp, yet the dudes sat down to dinner.

We had an unusually good dinner. It was very similar to our other meals, excepting lunch. We had hot soup, fresh elk tenderloin, and the usual canned vegetables, coffee and a fruit dessert.

After dinner the guides built a large campfire. We dudes and guides laid down by the side of it and warmed our- 
selves. In the meantime Joe and Hurricane Bill had returned and dined. They, too, gathered around the bright fire.

"Now, Percy," said Joe, after he had taken a good look at the grizzly pelt, "tell us all about how you shot the grizzly."

"Well, dudes and guides, Shorty and I tramped over there in the mountains," began Percy, pointing in the direction of the old mountain, where he had met the grizzly. "We got up past the fallen timber. We were sitting upon the side of the mountain of loose rock. It was very steep. I had tired of hearing Shorty always yelling to me to come on, so when we stopped to rest this time I took a few more steps and stopped a little above him and to his right, slightly. We had been sitting there whispering about where we expected to find a bull. The mountain was so steep that we were sitting up on our right feet, bracing ourselves with our left, holding our rifles ready over our right thighs. Everything was perfectly still. We had not the slightest idea of being charged by a bear. I looked up on hearing a terrible noise above me. It sounded like the whole mountain was coming down upon me. Upon looking up I saw a huge grizzly bear charging straight at me from a distance of possibly thirty-five or forty feet. I raised to my feet and took aim. A very precise aim, and fired. Shorty did the same and we fired almost simultaneously. Instantly the hind legs of the bear looked as if they were paralyzed; they gave down under her weight. She slid, trying to brace herself with her front feet. I fired again as she slid by, striking her in the top of the neck near the base of the skull. About twenty-five feet above me there stood an old dead tree, and, as she charged she had to come slightly to one side of this tree. She took the left side of it, and as she passed it, was when we fired. She was very close when I shot the second time-went sliding by about fifteen or twenty feet down, and when she passed she was perhaps eight to ten feet away. Oh, how she roared! When the bullet struck her she let out a dull awful howl. She clawed around 
and died facing me. God, how she did growl and snarl. Will I ever forget her snarling mouth and terrifying appearance as she lay there! I kept my rifle sighted on her eye until she ceased to growl, and until after the death rattle hushed-until after her eye became glassy and she ceased to breathe. I was watching every move intensely. I didn't know whether she would get up and come at me or not, so I took no chances. 'Don't shoot again, Percy,' yelled Shorty, 'she's dead, all right.' I told Shorty that I didn't care to take any chances and he walked on around behind the bear with his gun in hand, and cocked. The grizzly was dead. She must have been an awful old sinner, for she certainly died hard, appearing to dislike giving up and being subdued by a mere dude. Shorty poked her with his rifle from behind. She did not respond. I knew she was dead. I then walked down a few steps and viewed the queen of all the mountain kingdom. You should have seen that head-you should have seen her all snarled-seen the hair standing straight up, her mouth stretched wide; her tongue all curled back and her lips raised, ready to gobble me down. It was the greatest thrill I have ever had. I rather enjoyed the strait."

"You may never have such an experience as that again," interrupted Joe; and Percy said that he doubted if he did.

"Shorty and I," continued Percy, "caught a-hold of her front paws and stretched her out. My, she was a monster! And heavy? Well, I say she was. We took a good look at her, and while we viewed her peaceful remains, we heard a cub bear crying. The cub was down below us. It was a very pitiful cry. I started on down toward the cry, with my rifle. Shorty called me back and told me that we would doubtless have no luck in capturing the cub, as he found that the mother bear had no milk, and that he thought the cub was a yearling and old enough to have sense enough to 'high tail it.' His cries became fainter and fainter. Shorty and I then sharpened our knives. It was a wonderful sight to see Shorty operate on that old 
bear. I could hardly believe she was dead until I saw him take his knife and make a long incision down her center. Every inch of the skin had to be cut off of the bear. Shorty and I were busy there for an hour or so, skinning the bear. After we had cut the skin off and taken off the head, Shorty said that we had better take some bear fat with us, so I took my pruning knife and cut about thirty pounds off of the two rumps. I then hung it over my shoulders and Shorty wrapped himself in the bearhide and we came on to camp.

"One of the most interesting things about the whole affair was the sight of the grizzly bear after she had been skinned. She looked like a great big old fat man. There were the hands. Of course, Shorty and I took the skin off the paws so that the joints looked like the hand of a human, and when we finished it, it looked as if we had actually murdered a human being."

"They certainly do look like a dead man," interrupted Hardy, as Percy stopped to light his pipe, while the quartette joined in sonorously:

"It may be so, but we don't know;

It sounds so very queer.

We do not doubt your honest word,

Yet, your kybosh don't go here.

AMEN!"

Shorty stepped out and said that it was true, and very true, while Percy told them that he didn't care what they thought about it, as long as he was able to hear them express themselves, yet he did hope each one of them would have the pleasure of living through just such an experience.

"Well," said Percy, meditatively, "there is one thing about it I haven't told, which considerably amused me. After the bear was dead, and I had walked down to her head, Shorty took a few steps up to where I had stood and examined my tracks. I don't know why he did it," added Percy, smiling, "and then he told me that he thought my nerve was very good, indeed. I felt very glad to hear that 
from Shorty, but I want to say here, boys, that I didn't have time to be afraid, yet I was very happy to have had Shorty by my side at the time. When we finished skinning the bear we examined her to find where the bullets had struck her. We found the shot of Shorty had struck her in the stomach and the first bullet I fired had severed the spinal cord; and that my second bullet had also injured the cord and lodged in the base of the skull. The first bullet went through the breast of the bear, near the shoulder, going into and through the spinal cord. This bullet was fired in the bear as she charged; the next one was fired at the time the bear slid by, striking one of the vertebrae and then glancing into the base of the skull," concluded Percy, as he presented the bullets and passed them around for the party to examine.

"Oh! What wonderful souvenirs. Percy, you are the luckiest dude in all the mountains. I rather envy you. I do. I hate to kill these beautiful elk. I feel I am killing something I hadn't ought to, but a she grizzy bear, charging on you-well, Percy, that is indeed the king of all of the outdoor sports," said Joe, as he returned again from looking at the bear hide.

Bill said that he thought Percy was mighty fortunate: and then Floyd, while Ed said that he bane mighty glad: and Hardy added that he really would be d-d. Shorty told Percy that he undoubtedly would be the only dude, and we, the only party, in the state of Wyoming to get a grizzly bear this time of the year. (We were.) Percy asked why.

"At this time of the year, these old bear stay high in the mountains. It isn't the time to hunt bear, and it is only one chance in a great many that a hunter gets a bear in this way. That's the way to kill a bear-just to have them charge you when you are not expecting 'em-when you have to shoot or be eaten by the bear."

"Shorty," asked Floyd, "what if Percy hadn't killed that bear, what then?"

"Oh, nothing much. Nothing much-there would have 
been a lawyer's widow in Kansas City and a dude and a horse wrangler knocking upon the pearly gates. That's all." And Percy trembled as he put a firebrand to his pipe.

"Hey, Bill," shouted Percy, desiring to hear no more of the bear, "what did you do today? See any elk?"

"I had a most magnificent trip. I went out into the mountains, way, way out, into the mountains. We climbed and tramped, and struggled and climbed, and tramped, and got away over on top of another mountain range and there we came to a beautiful lake right in the top of a mountain. I sat upon a big rock on top and looked down into this wonderful lake. It was a great picture. It certainly was immense. Say, fellows, isn't this wonderful country? Indeed it is. I saw a number of bear tracks, didn't see any bear, but-I am glad that you got a grizzly, Percy."

"Shorty," interrupted Floyd, "you know a considerable about bears, grizzly bears. Do grizzly bears always charge a person like this one charged you and Percy?"

"Oh, not always; in fact, they seldom do," said Shorty; "they are not always on a tear. They are somewhat like a person-if they are grouchy and you interfere with their business, you are apt to get into it, yet, ordinarily, if they do not have cubs around, they are like black bears. If you come up close to where they are and do not bother them, they will 'high tail it'; that is, they will run off and leave you. If you go to encroaching upon what a grizzly thinks is his or her business-look out! Now, in this case, the thing that made this bear charge was that we had gotten between her and her cub; she had gotten our wind. She had a yearling cub, and I suppose that she thought we would cause the cub trouble. I think that's why she charged us."

"What about the black bear, will they charge you?"

"The black bear?" said Shorty astonished. "Why, they are like a rabbit. They will run off from you-the black and brown-although I would not want to corner them. I think the black and brown bear up in these mountains are 
all of the same family-blondes and brunettes. The old grizzly is the king of them all. He don't have to take any back talk from anything, or anybody. He knows his strength. He is always rough and ready."

"How did the Indians ever kill these big grizzlies?" asked a dude.

"Well, I don't believe the Indians ever killed very many of them until they got a large rifle. I don't believe they ever killed them with a bow and arrow. They might with a knife, although I would doubt it. They rather worshiped them. They were more of a god-that's the way the Indians used to think of them-they were so big and powerful."

"Say, Floyd, where have you been today?"

"Oh, Hardy and I have been tramping around upon the mountain tops. We have certainly had some grand views. And, whew, what thrills! Hardy and I climbed in places where I didn't think a mountain sheep could navigate, yet somehow or other, we would keep on going. He would say, 'Come on, Floyd.' And on we would go. We went over on that mountain range right directly back of camp and walked all over the top. There we saw those three peaks, and at the bottom the lake-Jackson's Lake, and the Great Tetons. It is a wonderful scene."

"How far away were we from that, Hardy?" asked Floyd.

"I should judge we were about thirty to thirty-five miles away from that," said Hardy, after figuring the distance.

"It didn't look that far to me, but I suppose it was. The air was very thin up wherc we were, and then we looked right over there from the top of another mountain."

The dudes and guides were lying around on the ground, smoking and resting.

"Say, Floyd, tell us a story. I've heard so much about bears, I'm actually afraid to go to bed. Tell us a pleasant story; something different," requested a dude.

"I'm not much of a story teller," said Floyd, apologetically, "yet I have in mind a different sort of a story. It is so different from what you ordinarily hear in the moun- 
tains; one of these citified stories. Maybe some of these guides will appreciate it. It is about a vampire-a wicked woman and a virtuous boy. Think I had better dare tell it in the presence of these gentlemen and dudes?" spoke Floyd jokingly, yet with a touch of sincerity.

"You want to be right tender with all of us, Floyd, but go ahead. The sky is the limit; and that is a long, long ways up even out here in these mountains," shouted Hardy, who was lying on his back looking at the stars.

\section{RAPHAEL AND THE VAMPIRE.}

"Say, Bill, if you and Percy don't care to hear this parlor story, you can go to bed or-jump in the creek, but for the benefit of these dude wranglers," said Floyd jocularly and yet with the attitude of a man who is about to tell a story in the presence of his wife which she might not approve, "back in one of the big cities there lived a boy named Raphael. He was the only son of a very wealthy man who, as his mother had put it, while her husband had made a great fortune and home on earth, she had her doubts as to his spiritual achievements and the home to which he had gone; and she, not desiring to miss Raphael in that fair land to which she, in all events, was going, had decided that the life of Raphael should be pure; that he should follow the paths of righteousness forever. Raphael's mother, of course, was an idealist. She had reached a mature age, doubtless of such maturity that some of the pleasures of youth appeared vanity to her, and vanity of the worst kind; yet, notwithstanding, she was the only proper person, in her opinion, to direct the youthful mind and raise her young son. Under such an environment Raphael had lived from birth. He was now a man physically; and, he being a man, it had occurred to the mother of Raphael that it must be a part of his life to, at least, as she confidentially expressed herself to an intimate friend, have an opportunity of looking over into the forbidden land; of beholding its fruit; to 
know the ways of the world, and from the awfulness he would profit.

"It happened that next door to Raphael there lived a grass widow, a beautiful blonde-rather a buxom vampire. Oh, boy! she had her charm; and the good folk of the neighborhood vowed as much experience. Of course, the old women of the community always had something to say about 'that' blonde, and some of the younger ones as well, yet she was wanted for a purpose by Raphael's mother, and under such a circumstance, was the proper one. Although some of the neighbors did wag their tongues when his mother told them of her intentions, Raphael and the blonde, or 'that blonde,' as she was better known, behind her back, went out together. They went down into the city-to the wild and wicked city, visiting the haunts of the poor miserable creatures who dwell in such places. Why, think of it! They attended a theater, which, as a friend of the mother of Raphael had declared, was a 'blaze of licentiousness'; and then, afterwards, a cabaret which was equally unrestrained by law. There they wined and dined. In the late hours of the night Raphael returned home. His mother had been sitting up for him, waiting for her boy. She had been greatly worried, wondering what the wicked woman had done to her virtuous boy. She went to his room. She found him pacing the floor desperately. He had removed his coat and vest, yet he prepared no further for bed. " 'Raphael, Raphael,' cried the mother, 'what did that wicked woman do to my bay??

" 'Oh, mother, it is too awful for me to tell you,' Raphael replied, crying and wringing his hands.

" 'My God' cried the mother, from the depths of her soul, 'what did that wicked woman do to my boy?' and she burst into tears; went to her room, prayed to God to forgive her and her blessed boy. Upon finishing her prayer, she again returned to her son.

"Raphael had ceased to pace the floor. He had flung 
himself upon his bed. He was crying as if his heart would break.

"'Raphael-dear, dear Raphael, what did that wicked woman do to you?'

" 'Oh, mother, if you must know, she told me there wasn't any SANTA CLAUS!'”

Hardy, who had been listening intently, said that he now really would be $\mathrm{d}-\mathrm{d}$; while the other guides voiced the notion that Raphael must have been an insipid Bible-backed youth.

September Fifth,

1917.

\section{CHAPTER XVII.}

"I wish you would look, Bill, at these lazy dudes," shouted Floyd, as he viewed Joe and Percy sleeping peacefully. "Get up from there; breakfast is nearly over."

Joe and I dressed and went to the river. Upon returning we were served a hunter's breakfast. It was very good. We enjoyed it and ate heartily.

No one was in a hurry this morning. Everybody was very tired. We leisurely walked about camp. We found Shorty busy fleshing my bear pelt. He was going over the whole hide, cutting the flesh and fatted particles from the skin. He then skinned the head of the bear. The skull was then put in a large bucket and placed upon the stove. It was boiled until all of the flesh loosened from the bone and slipped off.

"You'll need that, Percy, when you go to mount your bear. Be careful with it, and not lose it," said Shorty as he sat down and commenced again fleshing the hide.

"How do you prepare the bear pelt?" asked Percy.

Shorty finished fleshing it and stretched it out on the ground with the flesh side up. He salted it. "You take a lot of salt, after having fleshed it, and rub it into the skin; 
when it is thoroughly salted you lay it out, or hang it up, to dry."

"Do you have to stretch it out on a board?" inquired a dude.

"No, you do not have to do that. Some folks use to think it was best to do that, but that was a mistaken idea. We used to think we had to stretch our hides upon boards to keep them from shrinking, but the up-to-date taxidermist does not want it stretched. They say that when you stretch the hide, that way, you pull them out of shape. The taxidermist will soften them, and the hide will come back to its natural condition."

It was extremely interesting to me to consider the skull of the grizzly, after all of the meat had been taken from it, and compare it with the head of the bear while the skin and meat were upon it. The whole head of this grizzly was about the size of an ordinary water bucket before removing the skin and flesh, yet, after taking these portions off, the skull would have gone into a number ten or twelve shoe box. It resembled a human skull only slightly. It was very narrow across the eyes, and the distance between the top of the skull and the lower jaw was very small in comparison with the size of the head, considering it with the head of a human. It had very powerful jaws. The distance between the jaws was great enough to accommodate the ordinary head of a man; and, from the tendons which worked it, I am satisfied this grizzly was strong enough to cruch the head of a huma:? in one bite.

Shorty took practically all morning to prepare the pelt. Hardy was busy working upon the skull and hide of the bull of Floyd. Ed was busying himself about camp. cleaning the pots, pans, knives and forks and preparing dinner. He was the busiest man about camp, yet he often had time to tell us about "Yonesie ;" and "Yoe Yones." It was first one, and then the other. He talked a considerable about these two dignitaries of the mountains; and 
when one of the guides would speak of some one who might have lived in this vicinity a year or so ago, well, Ed could always name him, give a complete description and history. He was a walking directory of the inhabitants of Wapiti and Park county.

The weather was stormy today. It had been spitting snow; and then a terrible hail storm would blow up. It would sleet, rain or snow with equal ease. We dudes puttered around camp and hugged the cook stove, reading and smoking as our pleasure dictated.

"Isn't it interesting to watch the cloud formation," shouted Floyd, who had left the stove long enough to study the beauties of the mountain country in such weather. "B-r-r-r! Isn't it wild looking up there in the mountains? Look at that high peak over there. It looks as if a great white sheet had fallen over it, and it is hanging there. See how the clouds are constantly blowing around, and filling the mountains with mist and fog. I don't think it would be safe to hunt a day like today." And all of the dudes and guides decided that it would not be, as a dude or guide might step over a precipice.

Down into our happy valley swooped a driving, whirling snow and hail storm. How the sides of the tent did flap and its supports moan, as the wintry blast struck it. The dudes gathered in the cook tent and huddled about the stove, notwithstanding Ed suggested that "he bane afraid one of them would fall in the stew" which he was making for lunch.

After lunch Dude Bill started a pitch game, everybody joining in, gathering around the table. It went on furiously until Ed announced supper. It stopped and the dudes filled themselves with food.

"I had a thrill, boys," shouted Floyd, "I rode into and through a hornet's nest. Zippie, one of them struck the buckskin mare, and how she pranced and jumped. I felt about as safe as if I had been suspended over a precipice." 
"Well, Floyd," said Hardy, laughing, "I suppose we'll have to get a baby buggy for some of you dudes and we guides will push you up the mountain."

One of the dudes suggested that it would take at least a block and tackle, while another said he didn't have much trouble, although he did stop to rest occasionally.

The dudes smoked and returned to the sleeping tent. It was cold and damp, yet we all tucked ourselves in between the wet blankets and slept until morning.

\section{CHAPTER XVIII.}

We were awakened at seven o'clock. All of the dudes were still tired and sore. We dressed. Breakfast was ready for us.

"Well," said Joe, after thinking quietly for some time, "I wonder if Uncle Sam has called me-I wonder if they want me to go to France. Percy, that was where I was luckier than you ever were. I drew one of the first draft numbers of my district. I suppose I'll go to Camp Funston, or some other camp, as soon as I get out of the mountains. I hope I have time to at least say good-bye to my wife, and folks."

"You certainly are in luck, Joe," shouted dude Bill, "I wish I could go and wo 1ld if it were not for my defective vision-the loss of one eye-and I'd go straight to the front."

"You old gray-whiskered rascal, you would make some soldier," shouted Floyd, and after having received practically the same compliment from his friend Bill, the two dudes right shouldered arms and stood before the sleeping tent, awaiting their call to war, while Joe awaited the command from his superior officer.

"I left word back home for them to wire the sheriff. Could he find us?" 
"Can he find you? He has found many a rougher looking boy than you, Joe. Don't worry. You will receive word quick enough. They'd wire the sheriff, the sheriff would call up the forest ranger, his deputy would tell the game warden, and in a very little while they would locate you, although you are away out here," said Hardy.

Joe ceased to worry. The dudes picked up their guns and started for the mountains.

"Come on," shouted Shorty, and on went the tall one and the short one, leaving Ed to clean up camp and prepare supper.

The camp robbers flitted about the camp. They paid no particular attention to Ed; and I know Ed gave them equally as little consideration. I doubt if he saw them as they hopped around. (These camp robbers resemble a large bluejay, excepting in action and disposition. They are a harmless bird, and spend their time cleaning up old camp sites and giving their touch to the beauty of the country.) Lunch time came; and Ed, doubtless, like the hunters, ate a piece of cheese and a bun.

The huge shadows had fallen down the long eastern slopes of the mountains. From the north, east, south and west came tired hunters. They were dragging themselves back to camp.

"Hello, Hardy," shouted Percy, "I'm certainly glad to see you. There were times I had my doubts about it. I want to tell you that Shorty today 'got my mountain goat." " Percy put his rifle down and took a seat on the ground. "I never was so tired in my life; never have my feet hurt me so badly."

"This isn't a place for a tender plant. Shorty, you must be careful with Percy," said Hardy grinning.

"If you bane hungry, Percy, come and have a bowl of soup," said Ed sympathetically.

Floyd had returned. He too was very tired and his face was equally as red as he was tired.

"It's too bad about these tender plants! Why, there's 
my friend, Floyd; look at that handsome blue-eyed boy. $\mathrm{He}$ is a trifle mussed now, a considerably like a woodsman and a roughneck, with his whiskers, but Percy, do you know that when he was a baby his mother was just bothered nearly to death by the neighbors wanting to borrow her blue-eyed baby so that they could win a prize now and then at the baby show. He was, indeed, a handsome baby boy. He is a regular mountain climber now. He's a little fat-yet up here he'll outgrow that, but he has been stepping along all day, nearly wore me to a frazzle, that he did," said Hardy, as he laughed a wholesome and healthy laugh, and so did the other dudes, while Floyd blushed slightly.

We had dinner, although it was supper time in the mountains, and gathered around a campfire.

"Joe, you seem to be smiling all over, what kind of luck did you have?" shouted a dude. Joe took from his pocket a pair of elk tusks. He passed them around and all of the party declared themselves as to their wonderfulness.

"There wasn't very much to it, boys. Bill and I had been traveling most all day long. We had walked until three or four o'clock. I was getting terribly tired. $\mathrm{He}$ just says: 'there he is, Joe.' I pulled up and shot. The first shot I hit him. I fired three or four times and knocked him down, and that's about all there is to it. He didn't put up any fight and I just shot and killed him from about two hundred yards.'

Bill, upon being asked what luck, appeared slightly irritable. He had traveled into the dense wood, the fallen timber, had gone through it, to the high mountain pockets, over the top, yet he had not seen anything to shoot at. Of course, all of the dudes told him to cheer up and he would very likely have another chance the next day, yet Bill was tired and started to bed.

Joe told us, around the fire, that he was going to skin this elk and save the hide and have it tanned. Hardy then told us one of the best things elk hide was for was 
to "fix broken saddles and sech" in the mountains-that with elk hide you could fix anything if you knew just how to do it.

"Percy," said Joe, "tell us what you did."

"I think I wore about an inch off the bottom of my feet, fellows. My, they do hurt me."

"Oh, quit your kicking, Percy," shouted Floyd, while Percy said that that was one thing he couldn't do.

"Well, I'd rather go to bed, but if you must know, Shorty and I walked all over the mountains, and around the high peaks. We walked down; I slid and tumbled, and rolled. After we got up about to the rimrock we saw a number of elk. We came within a very few yards of a number of elk. We stood behind a tree and watched them. There were cows stationed on each side and end. The herd was feeding along the side of the mountain, up near the rimrock. Near the center of the herd there was a bull. He was standing up feeling mighty proud to think he owned his large spread. He looked to me to be a very good six pointer. I took a very careful aim from a distance of one hundred and seventy-five yards, maybe, not so far, and shot. The sun was shining over the trees and made his sides very white looking against the mountain background. I saw a little red spot come out of the side of the bull immediately after I shot. I attempted to fire again and my gun jammed. The whole herd started to 'mill' and in a few moments they all disappeared from our sight. The bull at which I had shot laid his head back, resting his antlers over his body, and glided away. We went up to where we had seen the bull standing. There was a slight evidence of blood. We followed the track until it disappeared in the forest. I felt very badly about having carried such a light caliber gun. I disliked injuring the fine animal, yet, I suppose he is now grazing upon the far away mountain side."

"Let us go to bed," shouted Joe. Everybody started slowly toward the sleeping tent. There lay Bill, sleep- 
ing peacefully, indeed, and soon were all of the other dudes.

\section{CHAPTER XIX.}

While the sun shone very brightly this morning the air was cold and crisp. The dudes had enjoyed a refreshing sleep. They were ready to start on another hunt.

Hurricane Bill had caught up two mules and the saddle horses for himself and his dude. They were going to bring in the meat they had bagged yesterday.

"Come on, Hal," shouted Bill, "let us try again today." Hal was feeling slightly irritated at their success. He was very anxious to give his dude a good shot at a bull, yet fate seemed to be against him.

"Percy, aren't you going hunting today?" asked Floyd, as he and his guide passed the tepee of Shorty, where they, found Percy stretched out on the pneumatic bed reading.

"Oh, my, no. My feet simply won't carry me today, so, my friend, the whole mountain kingdom is yours."

"Much obliged, Percy, I'll go out and use it," said Floyd as he and Hardy strolled off into the mountains.

Oh, how quiet it was about camp after the dudes had left. Ed was busy in the cook tent, yet he made no noise. There were the mountains everywhere, and the dudes were somewhere in them, yet they, like the game, were out of sight.

"Percy, oh, Percy!" cried Ed, "you bane able to eat some lunch?" And Percy limped into the cook tent, very much of the opinion that he was able to eat.

"I bane hope Billy has some luck today. He bane a nice feller, but you know you have to have luck at every. thing." 
"And that's why Bill hasn't shot anything as of yet. Do you cook all of the time, Ed?"

"Oh, no. I bane guide; horse wrangler, or cook. A feller up here in the mountains has to know how to do everything if he wants to keep busy. I bane busy 'most all time. Of course, some time there ain't much choice for me, yet, a feller out here, if he wants to work, and he bane any good, can generally keep busy."

"Do you ever read any out here, Ed?" asked Percy.

"Sometimes, but generally I bane too busy. There's always something to do. I suppose I better wash these dishes and start supper. When the boys come back they'll be very hungry-and that for certain. I believe I bane chop some wood; it is a pity these roughnecks never get time to chop wood; they always bane so full of wild stories." So Ed took the ax and chopped wood while Percy returned to his book.

What a wonderful day it was. How refreshing was the air!

"Powder River! Wapiti!" awakened Percy, who had gone to sleep over a novel which Bill had brought with him from the city.

"What luck, Floyd?"

"Oh, I got a big five-pointer."

"And aren't those some fine tusks!" said Percy as he stretched himself.

"You've a job for tomorrow."

"Look," cried Floyd, "here come Joe and Hurricane with their meat. We certainly have enough meat." Percy added that they had been out all day, expressing his desire to know what had kept them so long in the mountains.

"For God's sake, fellows," shouted Joe, as he approached his companions, "don't ever take the short way home. Bill and I certainly have been in a lot of trouble. We thought that we could cut across a mountain this morning and save a few hours time. We cut across, and 
got into a lot of fallen timber. We have spent nearly all day coming back, this short way of Bill's. It is a wonderful trail."

"You fellers bane better get ready for your supper, as it bane ready for you," said Ed, after sticking his head out of the cook tent.

Bill and Hal came in for supper. They were very tired, yet very well pleased over their day.

"Bill, tell us how you got the bob cat," shouted one of the dudes as he found a comfortable place around the campfire.

"Well, fellows, I'm mighty tired. I've had one of the longest tramps imaginable. The bob cat is too small. I want a big six-point bull, or a grizzly bear; and I don't care to tell about the bob cat any more than if I had killed a chipmunk." And dude Bill upon so declaring himself stood up by the fire and warmed his hands and back.

"And what did Floyd do?" asked Bill.

"Well, Bill," said another dude, "here are some new tusks of Floyd's; how do you like them?"

"Why, they are almost as good as his other pair."

"This matter of getting bull elk-well, Bill," said Floyd, laughing, and rather twitting Bill for his ill luck, "it is a simple little matter; all you have to do is to go out in the mountains and shoot them. If you don't knock them down the first time simply shoot them again; that's all. That's the way to do it, Bill. Try it on the next one you meet, and he will be your meat."

All of our party vowed that Floyd had the right idea, and being so thoroughly agreed we went to bed. 


\section{CHAPTER XX.}

The dudes were satisfied. They had gone into the far away mountains and bagged the big game. On every tree of any size about camp hung fresh meat. We spent the morning jerking it and hanging it over the smudge fire. Of course all of the meat had to be brought in, and that was another job for the dude who had meat in the mountains.

We spent two days in and about camp, preparing our fresh meat and resting. During this time we posed for a picture, which Bill desired, showing some of our trophies.

"Well, fellows, I rather dislike to think I haven't anything of value yet, but I am sure my luck will change," said Bill sadly after he viewed our various prizes.

"Yee Whiz, Bill," shouted Ed, "you will get the best one yet. It is just that way sometimes. You can't tell about a feller's luck." After Ed had finished giving Bill this consolation he returned to his work. He came out of the cook tent and made a very pleasant announcement.

"There is always one good thing about a fellow loafing "bout camp," said Ed, "he is regular for his meals." The dudes, notwithstanding the fact that they had been resting, were ready for dinner. They ate heartily, and spent the afternoon reading, and by six o'clock were again ready to eat.

Dude Bill and Hal came in with their fresh meat.

"Did you ever break trail?" inquired Shorty of Hardy, after we had gathered around our campfire.

"I broke trail once so much I actually got snow blind. It is awful to be snow blind. Your eyes get granulated, simply blistered from the light, and oh, how they pain you. It takes two or three weeks for them to get well. That certainly is hell."

"What do you mean by breaking trail?" asked dude Bill. He was told that sometimes in the mountains a 


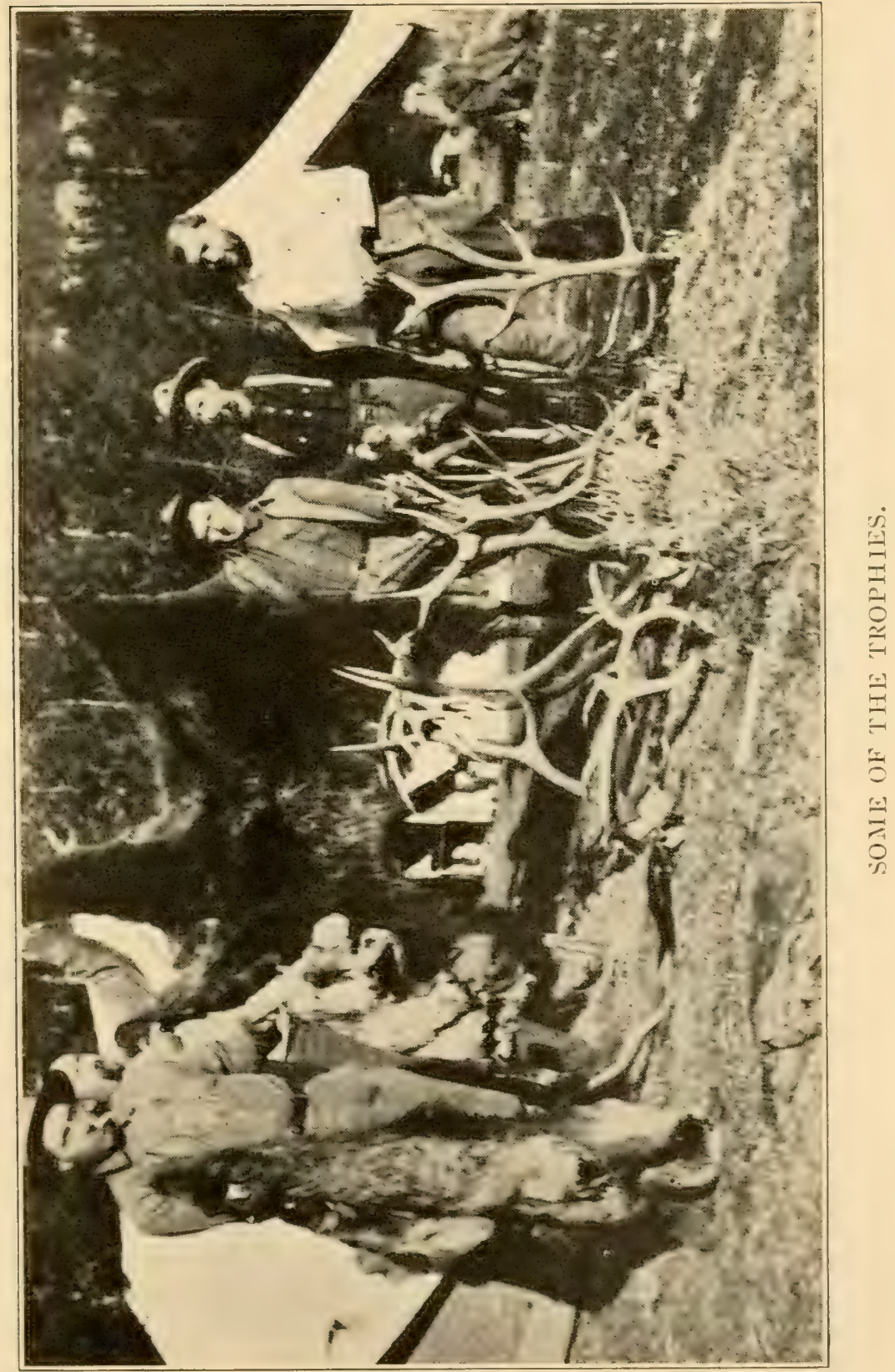



party would be caught in the snow-a heavy snow storm, and that it would be necessary to go ahead of the pack train and stamp the snow down so that the horses and mules could pass over it.

"Say, boy, that must be a job. I believe I had a little rather be at home in my warm living room than out breaking trail."

"Shorty," spoke one of the dudes, "did you know that fellow Gates, millionaire Gates, Charley Gates, who came out here?"

Shorty told us that he was well acquainted with Mr. Gates. In fact, he was the horse wrangler upon the trip of Mr. Gates.

"That was some party that Charley Gates put on out here; he took this very trip. It cost him about eight thousand dollars and he didn't get a grizzly and then he died in Cody right afterwards. He was a mighty liberal man-mighty good to his guides. Of course, he could easily afford to be that way-he had so much money; yet, with Mr. Gates, it wasn't so much the money, he was just as human as anybody, and a good fellow to boot. After he got back to Cody, the church people were all waiting for him, and had he lived long enough, I think he would have paid all of the debts of all of the churches, yet he wasn't a sanctified Bible backed dudehe was a real sport. I enjoyed being out with him."

"When Hurricane Bill and I were out today, I saw a porcupine; they are certainly a queer looking animal."

"Did you shoot it?" asked a dude.

"No, indeed! He wasn't bothering me, and I didn't care to disturb him, so I left him alone. He was so slow you could have taken a stick and killed him." Joe also said that he had seen quite a number of grouse, and that they were so tame, and so much like chicken he had left them alone. 


\section{CHAPTER XXI.}

The end of another perfect day had come to the dudes. The camp work had been done. The dudes, their guides, and the cook, had gathered around the open fire. They were smoking, thinking, and warming themselves.

"Oh, but that Billy, he bane a long walker," said Ed, as he stood up before the fire to stretch and warm his hands. "I like to hunt, and guide for Billy, but to walk all day, as he has, in a pair of shoes without any spikes, it bane awful, it bane. We didn't see anything but country. Billy he just keep on walking; and walking, and I keeps on walking. Finally I say, 'Billy, don't you bane tired? He say that maybe we bane rest; and then we sat down. We ate lunch, and then he strikes out again, and we bane walking ever since. I bane mighty tired, I bane I tank Billy and I ought to bane see a lot of game but we didn't." And dude Bill smiled to think he had made Ed tired.

"Floyd, have you bane in luck?" Ed said, grunting as if he were very tired.

"Hardy and I saw about twelve elk, and one very large bull. He was a big six-pointer. He was up high; the whole herd were standing in a huge snow bank when we saw them, the bull and all of them. I thought Hardy was going to shoot him. He raised his gun, and acted that way, and I didn't shoot; and in that way the bull got away. Hardy finally shot, but by that time it was too late, yet I thought he got him going over the mountain. His gun jammed the first time, and then he didn't have a very good shot. I could have shot him, if-"

"If he hadn't gotten away-say, boys, where's that little dog? Is he out here in the mountains?" shouted Bill, as he whistled for "the dog." Bill was assured that the same little old dog was often heard of in the mountains. "Say, Percy," said Floyd, "I see you are scraping on a 
new pair of teeth. Suppose you were lucky enough to kill another elk?"

"That I did, Floyd, and all by myself," Percy answered, while Joe said he would like to know how it all happened.

"Shorty and I had traveled all day long. I was very tired. We had gone up the creek, and the mountain, where I killed the grizzly. We had crawled around first one precipice and then another. We climbed down a rim rock wall, the steepest I have ever attempted. When I got to the bottom Shorty had another trip all planned out, while I had decided if I ever got to the bottom I would at least sit down and rest, so I told Shorty of my disposition. 'All right,' said he, 'just sit down and rest and then take that game trail back to camp, while I climb up in a couple more high pockets, and if I find any bulls I'll tell you about it and we can go there tomorrow.' So Shorty walked off and left me sitting on a big rock. I sat there and rubbed myl arm, took off my shoes and rubbed my feet and got all ready to go again, but was feeling so tired I just sat there. I saw a number of pretty little flowers, growing near me, so I picked some of them, and sat down and examined them very carefully. They were very pretty flowers. I fooled around, and then I found a comfortable place and laid down on the side of the mountain to rest. I don't know whether I went to sleep or not. Finally I decided that I believed it was time for me to limp on down the trail, so as to get in in time for supper, so I just strolled along. I had come to some fallen timber and was climbing slowly over it. Right ahead of me I saw a bull elk bound. I jumped over a log, took a few quick steps, slipped and fell. I stopped rolling shortly and decided that I hadn't lost that bull. I sat down on the side of the mountain to pick something out of my hand. Upon looking up I saw a bull elk-it must have been another bull-he was standing over on the other mountain about two hundred yards away, rubbing his horns against a tree. Now, boys, did you ever 
see such insistency on part of the animal kingdom to put themselves out for me? (And everybody vowed that I was as lucky as I was tired.) So I leaned back against the mountain side and took aim. I fired. The elk didn't appear to care much. The wind was blowing toward me, and, being on the other mountain, he didn't wind, or see, me. I emptied my automatic, reloading and fired again. Still the bull stood there. I was so far away that I couldn't tell whether I was striking the mountain or hitting the bull. I concluded I had better walk on over to where the bull was and, perhaps, I would have a better shot. As I started the bull started slowly to walk up the mountain side. I ran down my side of the mountain and came to a place where I thought I could jump across the creek. I jumped into the middle of the creek, slipped and rolled over in it. I climbed on up the mountain, toward where the bull had stood. I was beginning to be of the notion that I didn't have any particular liking for that bull, yet I had fallen in the creek, had a good wetting, so I climbed on. After climbing a few hundred yards up, I saw the bull standing high, upon the edge of a big boulder. I fired and down he tumbled and rolled on down to where I was standing. I stepped over and up to where he lay, thinking I would bleed him. He looked as if he were coming at me, so I made a stab and a cut for his throat."

"And you should have seen that slash, boys! Percy, nearly cut his head off," said Shorty, laughing.

"Well," said Percy, "I was all alone, and I wanted to be sure he was dead. I whistled for Shorty, sat down and dug his tusks out. After I had rested, Shorty came up and we prepared the elk."

"Ready, dudes, sing," shouted Floyd, as he stood up and led sonorously, the tune, which has been often mentioned, suggesting something about not doubting the honest word of the dude, yet, could not tolerate his "kybosh," whatever that is or was. 
"Say, Bill, dude Bill," shouted Shorty's dude, "when are you dudes going to take a bath?"

"Well, sir, I've had a number," said Bill slightly irritated.

And the dudes, for some reason, doubtless for good fellowship, yet maybe for other reasons, sang again the old refrain, and again suggested that the honest word of the dude was not doubted, yet his "kybosh" didn't go here.

Floyd must have been converted by the song as he said he would certainly take one tomorrow, while another dude vowed he was going to take one even if he had first to melt the snow or ice with the heat of his own body. Oh, how very rash it is to make a promise of this kind in the mountains! For by tomorrow the storms came. The wind grew icy, and the mountains were covered with snow. Yet there was the promise!

\section{CHAPTER XXII.}

The cold whirling snow of the equinoctial storm was being driven before a howling blast which swept down the mountain side. We were in the midst of what looked to be real winter. It was some time before the dudes aroused themselves from their slumber and shook from their beds the cold snow which had blown in under the sides of their tent, yet one by one they did, all forgetting the promise of the night before. All day long winter reigned sublime.

Shorty and his dude rode into the nearby mountain and brought in their fresh meat. What a sight it was when we reached the place where our meat lay. Everything was still, cold and covered with snow. The elk was cold and stiff. We quartered it and tied the meat onto the backs of our pack animals and rode back to camp. 
A pitch game had been started. Everybody stood or sat around a long log table and awaited what the wheels of chance had in store for them. The disagreeable day was forgotten and the dudes made merry at their game.

We were now laden with meat and trophies. We were ready to start back to civilization and our various pursuits.

Morning came. Oh, how wonderful, a morning in the snowy mountains, after the storm. How comforting the sun, as it appeared to beam from heaven itself, warming everything and everybody, rapidly driving away the snow. The mountain stream ran merrily along over its rocky bottom, giving its cheer as we prepared to say good-bye to this mountain kingdom.

Our tents were taken down, rolled and packed. Instead of supplies we had with us a large quantity of fresh elk meat and a great deal of jerked meat. We had room for everything and each mule and horse had an equal load.

The dudes were all very particular to see that their respective trophies were packed and not forgotten, especially one of the dudes. Oh, how careful he was about a certain old grizzly hide.

We rode back down the creek, through the deer and elk parks and around various mountains. On our way we saw a grouse sitting demurely in a spruce tree about a hundred yards to our right.

"Here, Percy! Hold my horse. I have been wanting to shoot a grouse for some time," whispered Joe, as he got of of his horse and pulled his high power thirty-thirty Winchester from its scabbard.

The pack train walked on, while Joe and I remained. Joe walked a few paces from where I remained holding his horse, raised his gun, took aim and fired. The grouse was decapitated. Joe walked over to where it had fallen and picked up the head and grouse. He brought both back. From all appearances the head had been cut off with a hatchet or a knife at the small portion of the neck. 
(And now my dear friend Joe is in the army-doubtless somewhere in France, with many, many other such American marksmen.)

We rode on and camped where we had previously, upon the north prong of Mountain Creek. The next day we packed on, following the same trail over which we had ridden in the beginning, and camped at what is commonly called Hawk's Rest. Here we pitched our tents-on the side of the mountain overlooking a vast stretch of flat country, through which the Yellowstone River wound its way.

Bridger Lake lay about fifteen or twenty minutes' walk ahead of us. The country surrounding this lake is wet and marshy. It is a disagreeable place to camp, so we camped under Hawk's Rest. Near our camp was a spring of cold pure water. It bubbled up out of the mountain side and then flowed on to the sea.

"Come on, boys, let's go fishing," shouted dude Bill, already armed with rod and reel. So the dudes and Hurricane Bill hurried away to the lake, while the other guides and the cook remained for camp work.

Bridger Lake is a sloughy body of water. It is full of fish. The dudes soon caught all of the fish (trout weighing from two to four pounds) on hook and line they felt disposed to carry back to camp.

"What are you going to do with those fish?" shouted Shorty to one of the fishermen who approached camp, very much elated over his catch. Shorty was told by the dude that he expected to clean them so we could have a fish dinner.

"You'd better examine the backbone of those fish first," added Shorty, smiling as if he possessed a superior knowledge of something important which he did not care to convey instantly.

We examined the fish and found to our sorrow that practically all of these fish were suffering from worms. Evidently they had a worm disease. These worms were found in the back of the fish, very close to the backbone. In this 
position of the body of the fish the worm would sap the vitality of the fish until the flesh of the fish had become soft and mushy. Of course, these fish were unfit to eat. We had to bury them.

"Now, wouldn't that spoil your taste for a fish supper?" said Joe, looking very disgusted. And it did.

There were a number of reasons given for these wormy fish. One, which appears reasonable, is that in this lake, as well as a great many of the other mountain lakes, there are hot springs. In this water the fish become sluggish and through their inactivity become wormy. Another reason given by some of the natives is that these fish in these mountain lakes feed from the fallings of pelicans, and from this falling there matures a worm which eats into the fish.

A few hundred yards from our camp was the camp of the game warden. He visited our camp and examined our trophies. He was a tall and lanky personage, and as pleasant as he was both tall and lanky. At the time he visited our camp he was out of fresh meat, so we had the pleasure of contributing to his sustenance a hind quarter of fresh elk meat. The game warden, commonly called "Dick," was spending his time on the hunting ground, according to the law of the state, where he had an opportunity to see the various hunters and what they killed. He had a little, shortlegged deputy with him, who carried more of the official personality than the warden himself on his short legs, one of them shorter than the other. The game warden very quickly became acquainted with all of the members of the party, and, of course, all of the dudes and guides, as well as our cook, who had long been his personal friend, called him by his first name.

Dick, the game warden, being so full of good fellowship, which was his inborn nature rather than the overflow of the bottle or selfishness, accepted our invitation to take dinner with us, after having thanked us and apologized for his coming in on us so unexpectedly-which, of course, as he put it, was not for the dinner or to see the trophies of- 
ficially, but, as I shall put it, to associate with his friends and to take a look at the dudes. What curious individuals we dudes must have been.

While we were being entertained by the game warden we had several changes of weather, developing from a pleasant day to a snowstorm; yet the pleasant day nor the snowstorm could possibly interfere with our dinner party.

Ed was very busy. In fact, he was the busiest man about camp. We were to be honored with the presence of the game warden and his deputy. This was indeed one of the social events of the community. In fact, all of the known inhabitants of the community were to dine together.

"For the love of Gawd! How's Ed," expostulated an old grizzly face, which possessed a long ragged gray mustache and a slouch hat over one eye.

" 'Lo, Dick," said Ed, "you bane in time for supper. I bane glad to see you. Come in." And in stepped a rawboned, rangy man of the West. He was tall and weather beaten. He might have been younger, yet he looked to be at least fifty-seven years of age. He wore chaps, boots and spurs, a flannel shirt and a vest, besides his slouch hat. Ed stopped cooking a moment and introduced his friend Dick to the dudes, adding that we had all better put ourselves in shape for dinner.

Further acquaintance with this newly-made friend revealed the fact that he was cowpuncher, or horse wrangler, for what we were told to be the Hollister Outfit, and that his horses had strayed so far from camp that his party hacl returned, on borrowed stock, leaving the said Dick to find the wandering horses. Of course, he had a "pardner," and he, too, was most cordially invited for dinner.

My! what open-hearted, frank people these men of the West really are. No previous arrangements had to be made before an invitation to dinner could be extended. It was simply: "Here, Dick, or Jim, or Joe, have a bowl of soup, some fresh elk meat, a cut of tenderloin; have some more beans; more bread-why, we have plenty of bread, and 
butter, too; help yourself to another cup of coffee; have another helping of potatoes and onions-here, boys, sliced pineapple for dessert. We have plenty of everything, so enjoy yourself and feed well." And so our dinner was served. What we lacked in style we made up in companionship and goodfellowship.

The cook tent, our banquet hall, was illuminated from a number of candles, which were sticking upon various boxes by virtue of their own wax. They threw a soft yellow light over the rough and bearded faces of both cowpuncher and dude alike; and while our dinner was not served in a blaze of splendor, yet we had plenty of everything-good, wholesome food and as much Wapiti society.

"Say, fellers," shouted Rangy Dick, "I found something in my pack which may add to the s-u-m-p-t-u-o-u-s-n-e-s-s of this magnificent occasion." And the "sumptuousness of this magnificent occasion" slipped from his lips with the same ease and grace as he produced from under his coat something in the shape of a bottle and yet more in the size of a jug. He told us very eloquently, indeed, that we, as a token of our friendship, should "touch our lips to it." Of course, there was no one present who really enjoyed drinking red liquor, yet, under the circumstances, it was a personal privilege, or, rather, from the action of the various parties, it so appeared, to partake of the hospitality of Rangy Dick.

"Joe," said Ed, after having had the said "wee touch," "have some more elk meat? Boys, won't you have something else? Well, I yudge you not bane hungry."

"Say, fellers," inquired a certain rangy individual, rather bashfully, "would it be ag'in your religion to start a poker game? The weather out is awful. How about a poker game?"

None of the dudes, of course, knew how to play poker; and I have never met many men who really thought they could - at least, they never, I dare venture, reached the age of maturity and still possessed that notion-yet when poker 
was suggested nobody started to run away. In fact, the table was cleared as if by magic, cards and chips produced. Someone was the banker, or at least acted like a bankerhe giving out, taking in and serving everybody, yet not putting in himself-and in a few moments those who enjoyed the game had an opportunity to delve into their pleasure to the fullest extent-and if they stayed long in the game, I would suggest that they could go equally as deep into their pockets; and those who didn't care much about it, but, under the circumstances and the awful weather, or some other handy excuse, w-o-u-l-d s-i-t i-n, could go equally as deep into their pleasure, or pockets either, on the command of the game, stud poker.

The game, like the storm, proceeded with fury, yet the interest of the game hushed the moaning of the storm to the ears of the players and bystanders. The keen-eyed players awaited patiently what fortune had in store for them. Some of them, and I will not mention any names, either-for who would like to be pointed out as a loser?-waited longer than others. And I may now suggest, for the purpose of bringing to my friends a true account of our trip, that the cold gray dawn of another day, all snowy, damp and cold, could have found the game in progress; yet the dudes, being used to going to bed early, and unaccustomerl to the late hours of Wapiti society, went to bed long before the old gray horse was staked, or that pair of spurs, or the saddle I won at the bucking contest, or what not; yet sufficient here to say that all of the participators in the pleasure were found the next day very much alive at breakfast. enjoying the same goodfellowship as of the night before. It was with some difficulty that I learned who had really covered himself with glory in the game. Nobody cared one way or the other. At least they never said anything about it. The game was a good one, fairly played, and, from the interest manifested, very enjoyable, so what cared the men of the West for the winnings or who possessed them! 


\section{CHAPTER XXIII.}

The clouds were hovering around the mountain peaks. They had filled the upper portion of the valley and were now frowning upon us and the rest of the world. The air was filled with moisture. It was cold and penetrating.

"Well, fellows, good weather or bad, I'm going to try hunting again," shouted Bill, as he wiped the frost from his Remington Automatic. "Come on, Hal. Let us go into the mountains. I expect to find my elk today. The snow may help us in tracking a big bull." So Hal and his dude saddled their horses and started out.

Hardy and Shorty believed they would take a stroll up the creek, suggesting that they might find the lost horses, while Floyd, Joe and Percy decided that they would go fishing in Yellowstone River.

The weather was not very good for fishing; and while I have fished a great many times and under various climatic conditions, I have seldom found the weather just right; yet the remaining dudes shouldered their fishing rods and started for the windings of the cold, clear Yellowstone River.

It was rather interesting to watch the three anglers. Isn't it wonderful how many, many things a person can learn on a farm? There was Joe; he could cast without any particular previous training. I think it came natural to him from driving a team or four horses-the cracking of his whipfor, oh, so nicely and precisely, too, could he cast his fly into the desired pool. And after he found he could do it with such accuracy, how intense he was in his sport! Floyd, at first, started to use his casting rod very much as if it were a fishing pole, and very shortly succeeded in catching himself in the seat of his trousers; yet he, being very quick to learn, soon acquired the art to some degree of proficiency. Oh, how carefully did the fishermen slide around through the willows, slipping up behind the banks and clumps of grass, or a tree stump; sometimes crawling on hands or knees or 
stomach. From the desired position the angler would cast his fly. Often the trout could be seen as he darted for the lure of the fly. The fisherman will inevitably smile as he, with his cunning art-or what he thinks to be cunning artreels in, and oh, how carefully, too, a two to four-pound trout. By four o'clock we caught all of the trout we desired and returned to camp.

"Let's start a pitch game. I believe a pitch game will go better than fishing in the snow," said one of the dudes. Hurricane Bill believed he would sit in, and so did Floyrl, Joe and Percy. The game progressed pleasantly. One of the dudes announced sonorously that he would bid four, when suddenly the music of a.feminine voice-it sounded very soft, sweet and alluring, I dare say, to the dudes, as it was a sound they had not heard since their departure-floated into their midst.

"Isn't this the dude party of Mr. Shorty Kelly?" asked the pleasant voice of Hardy, who was very busy at the time chopping wood, to the tune of a "cuss word song." $\mathrm{Mr}$. Hardy Shull had his back turned toward a mounted dudine. He stopped abruptly, and before his rhyming chant hari caused him to blunder socially he turned, placed his hancl over his mouth, as if he were laboring to hold in that which was about to slip out.

"Yes, mum," Hardy answered, endeavoring to hide an embarrassed grin with his large, well-tanned arm.

"I've been told," said the dudine, apologetically for her call, "that his dude killed a grizzly bear. Would it be asking too much to see his bear skin?"

"No, mum," said Hardy, pleasantly. It was with a considerable pride that he uncovered the king of all trophies.

At this particular moment the dudes had become too interested in the possessor of the velvety voice to carry on their game, so they each found a peep hole in the side of the tent and viewed the affair with that degree of curiosity which some neighbors often view the caller of another 
neighbor, who, well meaning, of course, has, unknown to the other neighbors, called the second time.

"Think of it!" cried a Mr. Dude, as he smiled and looked out into the snowy air through a convenient hole in the tent. "It is indeed too much. Yet, if she desires to see my bear skin (and when the dude said bear skin he acted mightily as if he meant bare skin) Hardy will be kind enough to show her the grizzly pelt."

"We have an invitation to dinner tomorrow," spoke an enthusiastic dude. "An invitation to what?" laughed ar1other. "An invitation to see her trophies!" emphasized the other, while the dudes smiled and looked knowingly at each other, and the dudine and her two daughters (one possibly nine years of age, the other twelve) rode away, after having thanked Hardy for his kindness, leaving the said Mr. Hardy Shull and the rest of his party in a high state of embarrassment.

The arrival of the little mother in khaki and her two daughters broke up the pitch game. The dude who had offered to bid four lost his chance forever of, as he put it, "shooting the moon." Of course, he had a thing or two to say about the dudine and her untimely call, while another vowed that she surely was his guardian angel.

"You dudes had better bane ready for your supper," shouted Ed slowly, as he looked about and saw the dudes still in a state of amazement. The dudes being ready (and I dare say had been ready for supper since they had finished their lunch, which was the usual kind of a bun and a slice of elk meat), started on a hot bowl of soup.

"I don't believe I would enjoy hunting in the snow very much today. I'll wager it is awful to tramp around in the mountains today. I'll wager, if Bill don't run onto a big bull or something, he will be one sore dude," spoke one of the dudes, as he filled his plate with fish and elk meat, beans and potatoes. Another dude reasoned that he didn't think it would make much difference whether he ran onto something or not; that he would be very sore anyhow-far 
more, of course, from action than disposition; while aniother said that he felt Bill would be successful as he harl generally found it to be that where a person worked, ot played, intensely, he would be successful.

"POWDER RIVER! WAPITI," shouted a familiaı voice.

"Why, there bane Billy now," shouted Ed, smiling as if he was very glad to have his friend Billy safe in camp.

"That sounds like he has killed an elk, or a bear," spoke one of the dudes excitedly.

All of the dudes left their supper and rushed to welcome their companion.

"You are right," shouted Bill faintly, "I got my bull today. I'm certainly glad I'm here. We have had a day of it."

"Billy, you bane hungry. You had better pitch in. These roughnecks will get the better of you. Yee whizz, but I'm glad to see you, Billy. Here, Billy, have a bowl of soup. We have fresh rainbow trout and elk tenderloin; what will you have?" Bill's pleasure was a considerable of everything.

After dinner the dudes and their guides, and Ed, gathered around a large campfire. They lay stretched upon the ground, which was covered with snow.

"Boys, I'm all in. I don't believe I was as tired in all of my life. This campfire certainly is a joy," said Bill, as he produced for our examination a large pair of elk tusks. They were a beautiful pair, and richly marked. From their appearance one could readily understand that they had tecently belonged to an old bull elk; and this was the declaration of all of the party.

"Say, Bill," said Joe, "did you kill him the first shot?"

"No," answered Bill, smiling, "it took eight shots to kill him. He was pretty badly shot up. The first shot was from the rear; and then he turned. He wasn't so far away, about a hundred and fifty yards-and then it was blewie! blewie! blewie! He hesitated. I ran up closer, firing as I went; then he was knocked down. Hal, you tell them the rest. By goodness, I'm tired; I want to get a smoke." 
"Well," said Hal, "we rode nearly all day-we got back 10 where we had our permanent camp. We were over behind that big mountain across the creek and back of our permanent camp site. There I ran onto him. He is a right nice animal. His beam measured the length of my Winchester. The only thing about it that is a job, is that it had tc happen about four o'clock. We'll have to go back and get it in the morning, and believe me it is in one hard place to get to-right in the midst of a lot of fallen timber."

"Say, fellows," remarked Bill, between the puffs of his cigar, "say we start back tomorrow. We want to fish at Eagle Creek, and we all have the limit, except me, and I can take a hike over into that portion of the hunting ground, called Canfield, and while I am hunting, you can fish for mountain trout."

So it was decided. We were to move camp on the following morning to what we were told to be Eagle Creek Falls, where trout fishing was the "best in the world," and Bill would have another chance for his second bull elk, or a bear or what not.

"I'm so tired and worn out, who would like to go back for the meat tomorrow with Hal?" asked Bill.

"I'll go," shouted Joe, "Hal and I will bring him in. We'll start about four or five o'clock, and in that way we'll overtake the pack."

"Now, isn't that like Joe?" said Hurricane Bill. "That boy's a wonder-always ready to go. He doesn't say much, but when he has a job, well, it is Joe for it. Fellows, I wish you could have seen Joe butcher his elk. He knows how to butcher."

"Yes," said Percy, "he appears to have learned something about everything on the farm-that's a great place to learn how to take care of yourself and be independent."

"I want to tell you," interrupted Bill, as he stood with his back to the fire, warming himself, "today has been a dandy. There is a lot of difference between climbing moun- 
tains after a little snow than when they are all dry. It did make me work."

"Well," said one of the guides, "if you would have stayed in our permanent camp a day or so longer, we would not had so much work. We were in the best place in the world for elk, but you dudes wanted to move on."

"That's always the case," replied a dude, "we are never satisfied with our location-yet Bill is now, so what care we, and besides, had we remained, Bill never would have had the pleasure of going back and tramping around the mountains so far from camp."

"Hal," spoke Joe, "how many shots hit the elk?"

"Six, six out of eight." Joe again repeated that that was the way to bag an elk-to shoot, and keep on shooting until he was down, adding that, of course, one shot might do it, but to make sure of not losing the fine animal, it would be well to keep on shooting until he was down.

"Ed, you have been sitting there looking into the fire for some time. What are you thinking about?" spoke a dude.

"Oh, I bane tanking, I bane. Yee whiz, it bane funny how a feller's mind wanders around-ha, ha-I bane tanking about-"

"A love affair," interrupted Floyd, laughing, as he winked at another dude.

"That I bane, Floyd-and a nice Swede girl she was, too. We were going to bane married. She said she loved me very much; and I bane believe she did; but I always bane such a harumscarum sort that one day I says, 'Nora, I don't bane of the notion we had better bane married,' so I pulled up and yump my yob and leave. She certainly bane a nice girl, though."

"That certainly was an act of kindness to her," said one of the guides, "Ed, but it might have been the making of you." And Ed bane of the notion it might.

"How did you happen out here in this country, Ed?" asked one of the dudes.

"Well," said Ed, "It bane like this: you get to moving 
about, working; working here and there, and here I amit bane a case of happen so, I guess. It was like this: one time, while I was working up there in the Dakotas-me and another fellow-we were going to town. We were on our way to a lumber camp for the winter. As we came to the railroad station there were two British officers. They spoke to us and asked us to go and fight forest fire, said that they wanted us to go to Nitchie, he would pay our way. Well, we bane tanking about it a few minutes, and then we started out.

"Yee whiz! a forest fire is an awful thing. You can hear it roar for several miles. It seems to blow and roar all of the time. It burns everything up in front of it. It runs very rapidly. The way we fought it was to burn back, or cut down some trees, and try to make a path wide enough so that the fire would not yump it. We would go about ten miles ahead of the fire and then saw down timber or burn back. In this way, in a long time, we got it stopped.

"After we were through fighting fire-well, we were about the only white people in the community. There were only these halfbreeds, French and Indian. While we were there a partner of mine-he was a sort of a wild man-and I thought we were going to have a considerable trouble with some of the natives up there. Well, one time we got into a saloon fight there-my partner and I-he took an old wagon spoke, and I grabbed of $f$ a bottle off the bar, and we cleaned up on the whole town. I thought we were in for it, but they only respected us; and after that they were the nicest kind of people to us. Just goes to show that every now and then you have to step right out and show who bane who, and why; but just traveling' round, is about the way I bane here in this work."

And so does the world often find useful work for many wanderers.

The campfire died down. Bill was a-snoring in the dude tent, and one by one the dudes and guides tucked themselves away in their wet and snowy blankets. 


\section{CHAPTER XXIV.}

The sixteenth day of September, 1917, again found us climbing to the top of the Continental Divide. After riding and walking to the top we had to go over and then down the trail which I have previously described; and it was with a great deal of pleasure to the party to find ourselves safe cn the other side. All of our party expressed our doubts of our ability to cross it in a heavy snowstorm, and just such a storm could be expected any time.

As we rode on we passed any number of bear tracks. Some of these bear must certainly have been monsters, judging from the imprint of their feet in the snow.

We packed on down the trail, it winding its way through the mountains, up and down, until we came to what we were told to be Eagle Creek Falls. Now, this is indeed a beautiful spot in the mountains. It is of a considerable altitude. Enough for the air to be cold and crisp. Our camp site was on the side of a high mountain, and along the side of it roared Eagle Creek Falls. Eagle Creek rises very near the Continental Divide, and at this point along its course it plunges down eight or nine falls, finally running into a lower valley, perhaps a quarter of a mile below; thence it pursues its windings until it reaches the Shoshone or Big Stinkum River.

After our camp was pitched the dudes strolled about the mountains on a reconnoitering expedition.

"Isn't this wonderful," said Bill, as he steadied himself on the top of a huge boulder overlooking the falls; "and aren't these rocks cut and carved peculiarly."

"They are that," said Hurricane Bill, as he came near. "Some of those cuts, of course, are made by nature, while others are made by man. I'm the man who made some of them." Of course, all of the dudes wanted to know further of what he had done here in the mountains, so he told us.

"My goodness! How time flies. It has been now nearly twenty years ago, a little more, I was prospecting out here 
in these mountains. My partner and I thought that we could change the stream of this creek and that in the bottom of that deep pool there, or the base of the fall, we could undoubtedly find a lot of gold. So we pitched into work and changed the course of the river through the rocks for the gold we supposed was at the bottom of the pool. We did all of this, but we didn't find any gold."

The current here was about four feet wide by two feet deep, and it had cut its way straight through the rocks.

The forests and mountains in and around Eagle Creek are a game preserve.

"There is certainly fine fishing down below the falls," said Hurricane Bill. "You can go down there and catch all you will want in an hour or so, if you know how."

"Let us go fishing," shouted dude Bill, so he and Floyd and Joe prepared themselves for trout fishing and started cut.

To reach the stream where the fishing was good from our camp site meant a hard climb down. It was necessary to walk down the ravine about a half a mile and then it was possible to climb down a wall of rock and in the course of nearly an hour one could land below ready to fish.

Percy having noticed the long walk and steep climb, decided that the time never was better for a cold plunge in the creek ahead of the falls, so he put in the rest of the afternoon very profitably.

"I wish those dudes would come on in for their supper," said Ed, as he stepped outside of the cook tent, "it bane ready for them." And I dare say the dudes were ready for their supper, yet they had gone fishing, down below, and the way up stood between them and their dinner. About an hour after dinner they came dragging themselves into camp, and were greeted with the usual good hunter's supper.

"That dudine had a dandy camp," said one of the dudes, "but that's all I can say for her. You are right, my friend, we were only invited to see her trophies ; and some very good ones, too, she had-but what got me was when we saw 
where they were smoking those fish caught out of Bridger Lake. They certainly were nice looking fish."

"Here, don't start anything about those Bridger Lake fish. Here, have some fresh trout!"

Did you ever eat any fresh mountain trout? If you have, it is my opinion that you could enjoy one now, even two or three, or three or four, or a half dozen. We ate heartily of the sweetmeats of the wild, as well as the canned food from the low countries.

"That dudine, by the way, fellows," said one of the dudes, "certainly had a nice camp-I am rather sorry she did not come out of her tent. I would have enjoyed seeing what sort of a person she really was. I hear you boys talking about her trophies, and all of that, yet I would like to know who she is, and why she is here in these mountains," spoke one of the dudes as he stretched himself before the campfire.

"You might go back and see her," added another dude; and the inquisitor said that he wouldn't cross the divide for the dearest girl in the mountains, while another added: "So be it."

The next day soon came to the dudes. Bill and Hal had decided to take a trip on further to Canfield Creek, where hunting was permissible, while Shorty and his dude felt disposed to fish; yet, of course, Shorty must round up the horses, so his dude climbed down to the creek far below, where he spent the day far from the voice of anyone, other than the voices of the forest and the monotonous discourse of the mountain stream.

"Hello, Joe," shouted Percy as he returned from his day of solitude, "did you get over into Canfield Creek?"

"Yes, but it was the worst trip I ever had. By the time we got there we had to start back; and besides, I wasn't hunting, anyway, just looking around. By the way, I lost my revolver. I had it strapped onto my saddle. We got into some of the worst fallen timber, just before you get to 
the top, and it got scraped off, so I have spent the day, Hurricane and I, without any protection of any kind."

"Well," said Percy, laughingly, "it didn't make any difference; you didn't meet a grizzly, did you?"

"No, we didn't meet anything-just had a hard trip; yet I am glad I went. The country was wonderful. The air was cold and crisp."

And in a little while Floyd and his guide, and Bill and $\mathrm{Hal}$ came into camp. They were all fagged out. Floyd limped slightly, and at intervals could be seen rubbing his elbow.

"Bill," asked Floyd, "did you have any luck in Canfield?" as Floyd busied himself rubbing his knee.

"Oh, we gat to see some tracks. We saw the tracks of an old bull-he must have been a very old bull, and a big one, too; his track was nearly as large as a moose track. I didn't get to see him. We had to go back just about the time we got to Canfield-it is so far away. Not so far away, either, yet the trip is very hard. I'm going again tomorrow and see that old bull-I'll be satisfied then.'

"Say, Hardy, what about spending the night in the mountains in Canfield?" inquired Bill.

Hardy said that it was a fine idea, and that he would like to go along with him. It was readily agreed that Bill and Hardy could have the pleasure of spending a night alone in the mountains, so that they would be ready for a hunt early in the morning.

"What's the matter with you, Floyd?" asked one of the dudes. Floyd told us that he had gotten into the worst places imaginable; and that while he was climbing down the side of a mountain, shouldering himself down a small dry rivulet, he had slipped, slid and fallen; and that he would have gone on down, what he thought to be a mile or so, had he not struck a small rock shelf.

"Oh, you will outgrow those bruises, Floyd. I thought at the time that we'd have to bring you back on a pack mule, but we didn't, and I think you are now a right live one," said Hardy. 
"Percy, did you catch any fish?" said Bill. Percy told his friends that he hadn't had any luck; that he honestly believed he was not onto catching mountain trout. He also said that he had found the rock formation so intensely interesting and the trees, and the meanderings of the stream, that really he was very satisfied with his day, while some of the party remarked that he had spent a $h-1$ of a day.

"Well, boys," said Bill, "I want to go over into the Canfield country again tomorrow. I'm awfully tired, but I want to take a look for that big bull. Say we go and spend the night and take an early morning hut?"

"All right," shouted Hardy, "I will be glad to go with you, Bill, and we'll surely get that old bull, if Floyd doesn't want to take a trip." Floyd very promptly informed us that he already had all of the elk the law allowed him and that he preferred to show Percy how to catch mountain trout.

\section{CHAPTER XXV.}

The morning of September the nineteenth, 1917, found the dudes all pursuing their various sports with a considerable keenness. Bill and Hardy had already saddled their horses, and with a day's provisions, had gone toward the Canfield country. They could be seen leading their horses as they crossed a faraway mountain range. They were mere specks in the distance, notwithstanding the clearness of the atmosphere. Floyd, Joe and Percy could be observed walking happily down a game trail which led to the valley below. These dudes were armed with fishing rods and flies. Their revolvers and rifles had been unloaded and left at camp. They were too heavy to carry comfortably, anyhow, and then, besides, as we were on a game preserve, it would not have been proper; so, of course, they were ieft at camp.

"Say, Hurricane," said Percy, confidentially, "I didn't 
have any luck yesterday fishing-tell me how you catch these little fellows."

"Well, Percy," said Hurricane, smilingly, "they are right sharp. You must have the 'savvy' to catch them. If you will watch me a while you will very quickly learn. The first thing you want is to put on some small flies. Of course, you want a very light line. You don't need a sinker-if you think you must have one, in order to cast precisely, take a very small bullet-yet you will get along just as well without it. You have to slip up behind a tree or rock-do it very carefully; and be sure you are on the side of the stream so the sun will not throw your shadow into the water - so that the fish will not see the shadow of your pole or line. You cast your flies over very carefully, being sure not to disturb the water, ahead of the pool where you expect to catch your trout-then draw your flies down the stream just a little faster than the current. When you get a strike, don't try to jerk the trout out, but simply, as the old colored man says: 'Just ease 'em out,' and do it, oh, so gently that you will not disturb the others. You must always bear in mind that if the trout see you they will not bite or strike until they are certain there is no danger. Just watch me for a while and you'll have no trouble, I'm sure."

"Here, Joe," whispered Percy, as we approached the portion of the stream we thought good fishing, "take my waders. I'm going to watch Hurricane Bill a while."

Joe took the waders and very shortly he was pulling the fish out; sometimes he would get two on a single cast. $\mathrm{He}$ was indeed an expert, and lucky as well. Floyd was down the stream doing the same thing, and so was Hurricane Bill. After Joe caught quite a string Percy took the waders and then he began to catch them.

"And to think that I couldn't catch any yesterday; why, the idea," chuckled Percy. "But it's like everything else: as Bill puts it, 'If you ain't got the savvy,' you can't catch any fish, or anything else, as far as that is concerned." 


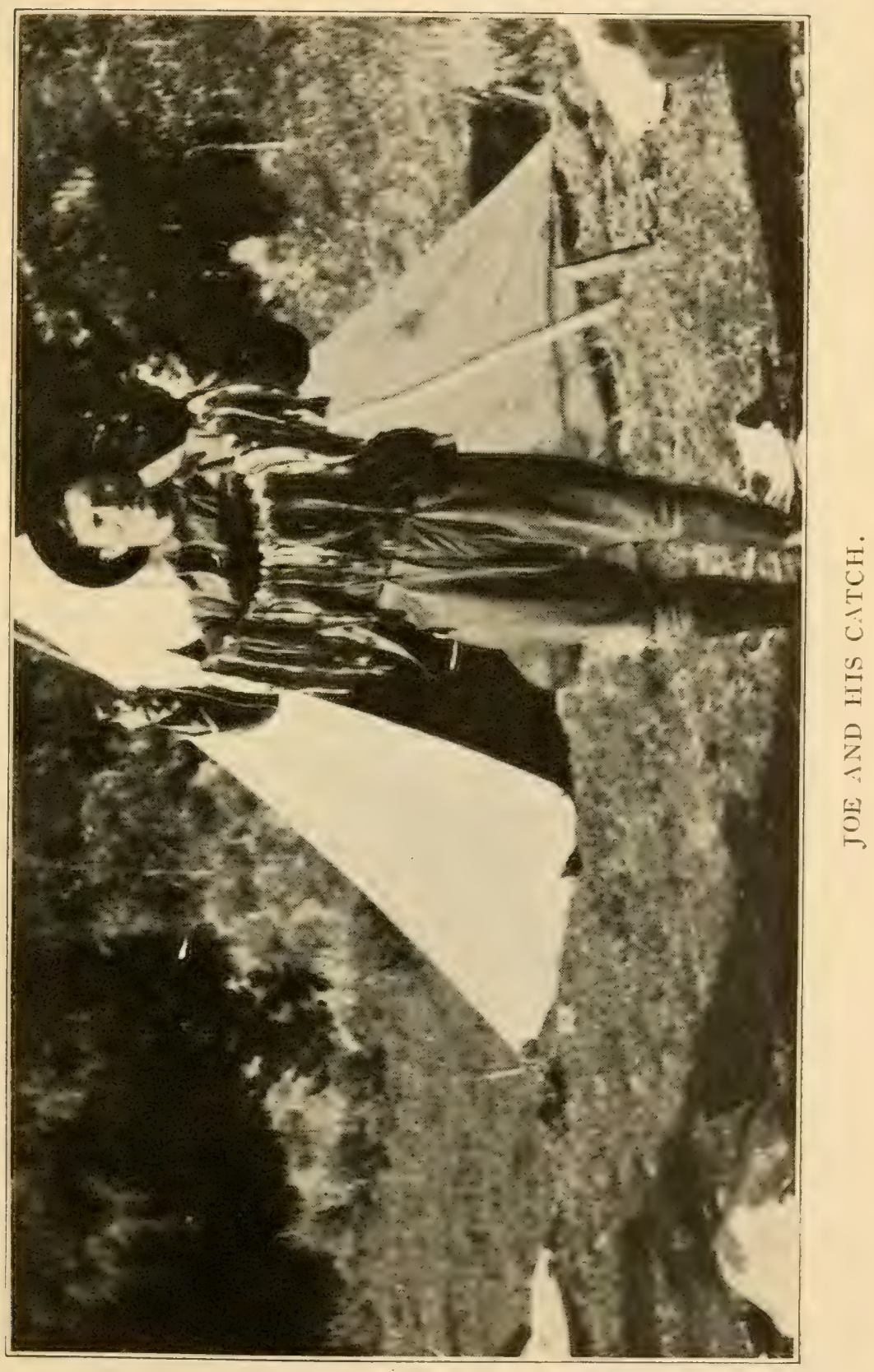



And this dude hid behind a big rock and continued casting, much to his delight.

So the anglers spent the day. They were so intense that they forgot their lunch; at least, I never saw any of them eating any of it. We had a wonderful day. Indeed, we were exceptionally fortunate. How we were blessed with this opportunity, the companionship, strength and courage for such pleasures. We all caught beautiful strings of trout. When the shades of evening had begun to fallwhen the air was being cooled and chilled from lack of sunshine, caused by it sinking behind the mountain tops-we started up what then appeared to be a long, long trail to our refuge in the high mountains. Isn't it inspiring to know that the campfire is burning for you after just such a day? And equally encouraging in life, so to live, that the campfire of your evening tide will be burning for your return after your day is done!

"Boys," shouted one of the dudes, as he and the rest of the party stopped to regain their wind, after a climb, "I think I could spend the night here, if it wasn't my notion that dear old Ed "bane waiting with a hot bowl of soup."

Floyd laughed, and so did Joe and Hurricane; and then we trudged on, and sure enough when we arrived at camp we were so welcomed.

"Joe, while the sun is reflecting here from that old mountain, let me take your picture with that string of trout," cried Floyd, as a man would who had thought of a bright idea.

"Yee whiz! You fellers bane hungry at all," shouted Ed.

"But we want some fresh trout for supper," replied Floyd.

"That we'll have, Floyd. Here, Ed, I've cleaned this string - they are ready for cooking," shouted another dude.

"All right, boys; I'll cook the fish while you fishermen bane wash yourselves."

My friends, you can imagine how we ate. I know you would have enjoyed supper with us tonight. Of course, it vasn't served with much style, yet it was: "Have a hot 
bowl of soup? Very well, have another. All right, let me help you to some nice fresh trout? Also, permit me to serve you with a goodly portion of potatoes, onions and beans. I almost forgot something, let me help you to a nice cut of elk tenderloin? You will like it, it is well seasoned and cooked to your taste. Here, pray help yourself to some hot bread. You will find the butter there on the box. Oh, yes, you have your butterknife in your handjust stick it in that cask of butter. My, my! Did you really have fish? I could hardly believe it. Of course, there is plenty more-here, two nice plump trout for you. Oh, yes, another cup of coffee-certainly. Will you have cream? There is the sugar. Just help yourself. Some more hot bread? Yes, it very quickly disappears. Here, lave some more beans and potatoes. What? Don't care for any more? Well, I have sliced pineapple for dessert, or peaches. What will your pleasure be? Pineapple? Well, have some peaches, too. Why, certainly, Ed has baked a cake. Here, have a slice of cake. Ed, that was thoughtful of you. Here, take another slice of cake so as to go with the peaches. Yes, indeed! We have cold water. Here is a whole bucket full. Here, hand my friend the gourd. Pardon me, please, I must have it back again; you see, Bill aiso wants a drink. You'll have to excuse the number of dishes and cups, but you see in traveling through the mountains we can't take a hotel outfit with us. Now, did you enjoy your dinner? Well, here are some choice cigars. What? Don't care to smoke cigars? Very well-here are some nice cigarettes-or here is a fresh corncob pipe for you. Now, what kind of tobacco would you like? Indeed, here it is. Now, will you sit by the fire in the cook tent, or will you come out into our living room? Suit yourself, my friend. You will find the living room very large and roomy. You can warm yourself near a blazing fire." And so the world went in and about our camp. I might add, if my friend would be so gracious as to desire to spend the 
night with our party we would have had room for him, and he could suit himself as to his bedroom. For instance, he could sleep on a pile of rock, or sleep in Bill's bed on a pile of rock which had been thoroughly covered with spruce boughs; and I dare say, if he awoke in time for breakfast -and I'm certain he would have, as the dudes would have attended to that-he would have found the same genial goodfellowship as of the night before.

\section{CHAPTER XXVI.}

We had been smoking our fresh meat from time to time with a great deal of pains. It was practically cured. We had jerked enough so each dude could take four or five hundred pounds of it home with him. Today we were to put the finishing touch to its cure, so a smudge fire was built under the meat. It was packed the same as we had many times before. Our custom was to leave the camp and the jerked meat in the charge of Ed. He would keep the smudge burning. We were all very proud of the reward we expected to take back with us, and, doubtless, each dude had visions of going to his larder in the winter to come and taking from it a few more pounds of the jerked meat. I think the visions were so vivid and strong that the dudes could almost taste the meat and see the bright eyes of their friends as they would feast upon this rare food of the wild. So the camp was left to our dear old friend Ed today the same as usual. We knew he would protect anything we had. Why, hadn't we all given him our watches and money to keep for us? And wouldn't the whole stake have tempter? some folk? Yes, very sorely, I venture, yet not our friend Ed. Of course not! Who couldn't trust that honest Swedish man? I say man because from my acquaintance with him I know him to be such. 
We returned at the end of another perfect day of fishing and found the charred remains of our jerked meat. It was all destroyed. The smudge fire had blazed. Ed was busy in the cook tent. The meat had burned before he noticed it. He was nearly broken hearted over our loss. We all regretted it very much.

"POWDER RIVER! WAPITI!" shouted a familiar voice from the nearby thicket.

"There bane Billy - there he bane! He's got another elk. Yee whizz, that's good," said Ed; and through the timber and brush back of our camp wè heard our friends approach. They rode up to camp, unsaddled and unpacked their meat, which Bill had killed in Canfield. Bill was very tired. $\mathrm{He}$ went to the river to wash. On his way he saw the ruin the smudge fire had made.

"Now, don't that beat hell," said Bill seriously, "but such is life." And Bill went on to the river and washed. While there one of the other dudes told him how it happened.

"And I know Ed is nearly broken hearted-well, well, he'll have to forget it. It is gone-we have lost it-so why lose more by worrying about it!"

"Billy, I bane mighty glad you got another elk," said Ed, with a considerable sadness in his voice, "and mighty sorry the meat all burned."

"Yes, Ed," shouted Bill; "I was in luck today-we have plenty of fresh meat. I got a good bull today, or rather yesterday. Here are the tusks."

"They bane nice ones, Billy, they bane. They'll make a nice pair of hatpins for your wife."

"Bill, tell us about it," shouted one of the dudes over his dinner.

"Wait until I eat-why, I'm as hungry as a bear."

We enjoyed another good dinner. We had plenty of everything and equally as good appetites.

"Now, Bill," said Floyd, as we all sat around the campfire in our great living room, "tell us all about it."

"Well, boys, you all know where Canfield is, don't you?" 
"Yes," shouted Percy; "as far as I'm concerned, it is somewhere in the Rocky Mountains. Where is it, Bill? You will remember I haven't been over there."

"Oh, yes, that's a fact, Bill; we have a tender plant with us," said Hardy, and then he laughed, and by the campfire he nudged Floyd, who winked as if to say, "He is that," while Percy didn't care much what kind of a plant he was so long as his game license was full.

"Well, Percy, you know that this Eagle Creek country is a game preserve? (And Percy said that he believed he had been so informed.) All you have to do is to cross over that mountain range over there, back of camp, over the top, so to speak, and you come to the Canfield country. On the other side of the Canfield country is the Yellowstone Park-which, of course, is another game preserve-so this country lying in between, in my opinion, is an extremely good place to hunt as it lies between the two preserves. Canfield creek is inaccessible from its mouth; at least that's what Hardy says, and if he says so, I am inclined to believe it. If it is any worse than the entrance from the top of the ridge, I don't want to go that way; and I don't blame anybody for not hunting elk there. We rode on, walking, climbing and leading our horses, from time to time, as we went. Our line of travel led us through fallen timber, over loose rock, and in almost every sort of jungle imaginable. Shortly after noon we reached the top of the ridge and rode into the Canfield couniry. After going a short distance we tethered our horses, and walked on afoot.

"'There!' whispered Hardy. I looked up and saw the elk I thought I had seen the evening before-he was a big, fine animal. He must have thought we were other elk. We were surprised to see him walking leisurely towards us. I counted the prongs of his antlers. He had a big, heavy beam, but only five points. I wanted a six-pointer, but Hardy said that he would be as good as we could get, so I raised my rifle and fired. He turned and jumped as if something was wrong with him, and staggered back over a 
ridge. I thought surely he was mortally wounded, yet when we reached the other side, where we could have seen him, he had gone. He left a trail of blood, so I knew I had struck him. His trail led over fallen timber and through some of the worst kind of places. We had about given up locating him. Finally we came to a very large meadow. Hardy told me to go around to the other end of the meadow, and that possibly I would see him and get a shot. It took me about a half hour to get around to the other end; and when I got there I noticed through a few trees another large meadow. I decided to go over into this one and take a look. To my delight, when I got to the edge of the next meadow, I saw the same bull, about seventy-five feet away from me. I raised my rifle and fired. I wanted to make sure, so I fired again instantly and he fell. Hardy heard the shooting and came to my assistance. We then cleaned the bull and propped him open and left him to cool. He was a very large bull, weighing something over nine hundred pounds. I was, and am, slightly disappointed with his antlers. Yet, as you see there, boys, he is a reasonably good specimen."

"Ready, fellows, sing," shouted Floyd; and we dudes, and guides, too, as far as that was concerned, joined hands and sang an old-time tune, the words of which, while, of course, they never questioned the honest word of our friend, to say the least, were offered for our pleasure; and when the mountains echoed with the grand amen, dude Bill started the song again, and with sonorous voices we all joined in. Everybody then found another comfortable spot by the fire.

"Boys," said Bill, and then he took a long look into the fire, "let me repeat again how I enjoy the campfire. Here we are alone in the mountains, yet of course the campfire and our friends have completely destroyed all signs of loneliness. Still, I must confess, when I look out over the mountain tops, I am reminded of last night."

"What about last night, Bill? Were the coyotes to the right of you; grizzly bears to the left of you; mountain lions 
behind you? And did they all roar and thunder? Say, Bill, what about last night?"

"It was a big night, and very interesting to me. After we had prepared our meat for cooling we tramped back and found our horses. We then began to look for a place to sleep. I was tired; never was so tired. We found a cut or a shelf in the rim rock. Here we built a big fire. Hardy cooked a little food, and after supper we stretched out for the night before the fire. We took a couple of blankets with us. Hardy gave me to understand that we could both go to sleep or he would keep watch a portion of the night, and I could do the same. So saying. and without further comment, he rolled up in his blanket and was soon sleeping as peacefully as a little child. How some folk would have envied his sleep! He was so well; so healthy; so free from care, that he could lie down on the mountain side, and I dare say, if he were a dreamer, he could dream a grander dream than that of prince or potentate. Soon old Mr. and Mrs. Coyote started their yelling, and all sorts of weird sounds of the forest broke the stillness of the mountains. Hardy had the big end of the work to do. He was sleeping so peacefully that I did not have the heart to call him! and then I was enjoying the night and many happy reminiscences. Occasionally I would feel the need of sleep and then I would hear a fiendish yell. I would unconsciously put my hand upon my automatic; and th $2 n$, smile to think I had been so effected. When Hardy awoke, at the gray dawn of today, he swore jokingly at me for not having awakened him-but out there, alone in the mountains, I was pleasantly entertained. In fancy I journeyed over the great chasms, and tipped the far and distant sky lines. I wondered what monsters lurked near me! and then, my mind wandered, drifting ever eastward, back to home; my lovely wife; to the homes of all of my friends; and there, I could see, in the stillness of the night, the dear ones ever awaiting; and sometimes, I thought, anxiously 
too, for the return of their loved ones-and so ran the night. Boys, isn't our time nearly up? I fear I must hurry home. What say you? Say, we fish tomorrow; and then take the trail?"

"Indeed," shouted one of the dudes, "it is a long, long trail, ever leading eastward. I'm ready to go, too; aren't you?"

"Yes, I'm ready," cried another, "but the worst of it all is to leave my friends-Hardy, Shorty, Hal, Ed, and Hurricane; and then each one of the dudes. My heart is too full to say good-bye, so let us now say, goodnight; and I know the time will too soon come when we shall all have to say, good-bye."

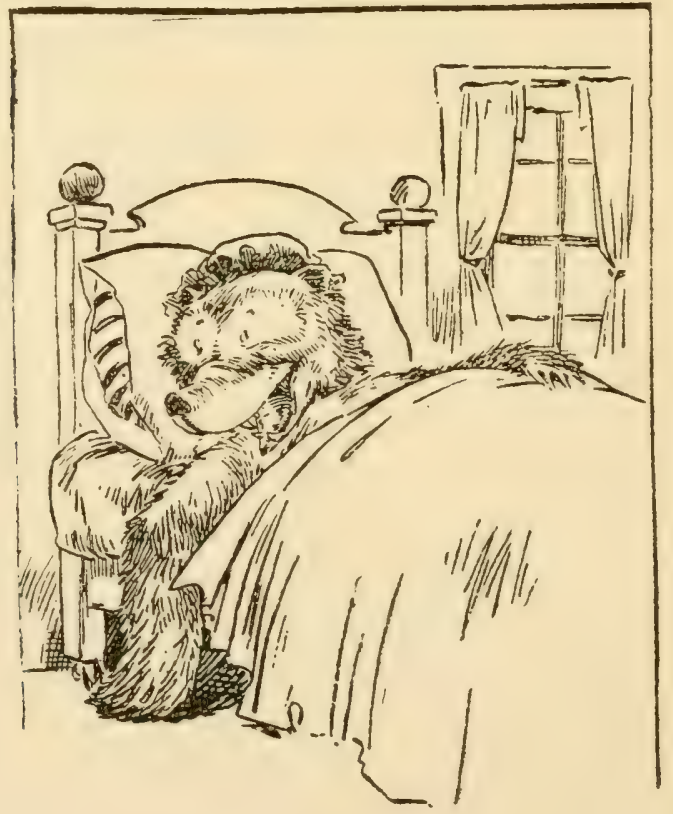

THE END. 





\section{LIBRARY OF CONGRESS}

|||||||||||||||||||||||||||||||||||||||||||

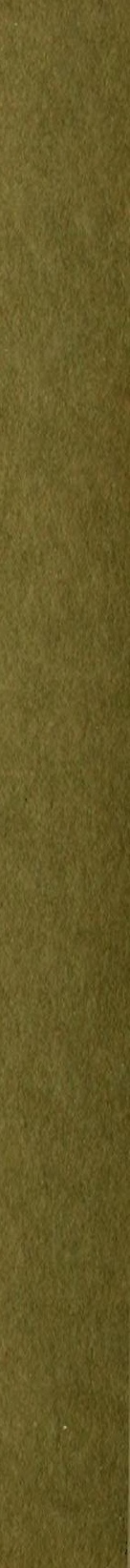

